\title{
Coral and Coral-Associated Microorganisms: A Prolific Source of Potential Bioactive Natural Products
}

\author{
Vo Thanh Sang ${ }^{1,+}$, Ton That Huu Dat ${ }^{2,+}\left(\mathbb{D}\right.$, Le Ba Vinh ${ }^{3,4}$, Le Canh Viet Cuong ${ }^{2}$, \\ Phung Thi Thuy Oanh ${ }^{2}$, Hoang Ha ${ }^{5}$, Young Ho Kim ${ }^{3, *}$, Hoang Le Tuan Anh ${ }^{2,6, *}$ and \\ Seo Young Yang ${ }^{3, *(D)}$ \\ 1 NTT Hi-Tech Institute, Nguyen Tat Thanh University, 300A Nguyen Tat Thanh, District 5, \\ Ho Chi Minh City 748000, Vietnam \\ 2 Mientrung Institute for Scientific Research, Vietnam Academy of Science and Technology, \\ 321 Huynh Thuc Khang, Hue City, Thua Thien Hue 531600, Vietnam \\ 3 College of Pharmacy, Chungnam National University, Daejeon 34134, Korea \\ 4 Institute of Marine Biochemistry, Vietnam Academy of Science and Technology, 18 Hoang Quoc Viet, \\ Cau Giay, Ha Noi 100000, Vietnam \\ 5 Institute of Biotechnology, Vietnam Academy of Science and Technology, 18 Hoang Quoc Viet, Cau Giay, \\ Ha Noi 122300, Vietnam \\ 6 Graduated University of Science and Technology, VAST, 18 Hoang Quoc Viet, Cau Giay, \\ Ha Noi 122300, Vietnam \\ * Correspondence: yhk@cnu.ac.kr (Y.H.K.); hoangletuananh@hotmail.com (H.L.T.A.); syyang@cnu.ac.kr \\ (S.Y.Y.); Tel.: +82-42-821-5933 (Y.H.K.); +84-948151838 (H.L.T.A.); +82-42-821-7321 (S.Y.Y.) \\ + These authors contributed equally to this work.
}

Received: 7 June 2019; Accepted: 7 August 2019; Published: 11 August 2019

\begin{abstract}
Marine invertebrates and their associated microorganisms are rich sources of bioactive compounds. Among them, coral and its associated microorganisms are promising providers of marine bioactive compounds. The present review provides an overview of bioactive compounds that are produced by corals and coral-associated microorganisms, covering the literature from 2010 to March 2019. Accordingly, 245 natural products that possess a wide range of potent bioactivities, such as anti-inflammatory, cytotoxic, antimicrobial, antivirus, and antifouling activities, among others, are described in this review.
\end{abstract}

Keywords: bioactive compounds; coral; coral-associated microorganisms; natural products

\section{Introduction}

Marine environments are among the richest and most diverse ecosystems, with an enormous diversity of different life forms. Harsh chemical and physical conditions in the marine environment are important drivers for the production of a wide range of bioactive natural products with structurally unique features [1-3]. These marine natural products exhibit a variety of bioactivities that have potential applications in the pharmaceutical and medical fields.

Marine natural products, especially those from marine invertebrates, are used naturally as a chemical defense to protect organisms from predators, stressful environments, and the encroachment of competitors [4-8]. Due to bioactive and structural diversity, the natural products from marine organisms are considered to be an extraordinary source of new therapeutics that exhibit structural and chemical features not found in the terrestrial environment [9-13]. More than 20,000 novel compounds have been isolated and identified from marine organisms over the past 50 years [14], and more than 300 patents have been approved [15]. In particular, several current drugs and drug candidates in preclinical or clinical trials have been developed from marine natural products $[10,12,14,16]$. 
Among marine organisms, soft corals are promising providers of marine bioactive compounds and have received considerable attention. Many bioactive natural products with structurally diverse features including terpenoids, diterpenoids, sesquiterpenoids, steroids, and other chemical compounds have been produced by various species of soft corals [17-21]. It has been estimated that the new compounds isolated and identified from soft corals represent more than $20 \%$ of the total new marine natural products reported from 2010 to 2011 [17,18]. Importantly, the natural compounds isolated from soft corals exhibit a spectrum of biological activities, such as antimicrobial, anticancer, anti-inflammatory, antiviral, and antifouling activities [17-19,21,22].

Corals are also known to harbor diverse and highly abundant microbial communities [23-28]. It has been reported that coral's microbial communities are partially species-specific $[25,29,30]$ and that shifts in the composition of the coral microbiome are related to changes in coral health, the appearance of signs of diseases and/or bleaching, resistance to stressors, and the stability of reef ecosystems [31-36]. Past investigations have revealed that the coral microbiome plays an important role in the protection of the coral hosts by producing antimicrobial compounds, inhibiting pathogenic catabolic enzymes, disrupting cell-to-cell communication in pathogens, and competitively excluding pathogens from host surfaces $[31,35,37-40]$. Coral-associated bacteria can produce many structurally diverse compounds with a wide range of bioactivities, including antimicrobial compounds, against a broad spectrum of pathogens of corals $[38,40]$. Thus, not only coral, but also coral-associated microorganisms, are considered to be extraordinary sources of bioactive natural products.

In the past few decades, repeated isolation of known secondary metabolites and a decrease of novel compounds discovered from terrestrial environments have limited the development of new drugs for treating increasing diseases [41]. Particularly, arising drug resistance presents an urgent requirement for the discovery of new bioactive compounds from the marine environment. Hence, the discovery of novel pharmaceutical compounds from the marine environment such as coral and its associated microorganisms is a promising strategy. There have been several reviews on natural products from coral and coral-derived microorganisms over the past few decades. However, these reviews have reported partially on natural products from several specific coral groups/specific structure classes [20,42-45] or were part of annual reviews about marine natural products [46]. In the present review, we provide a comprehensive overview of bioactive compounds produced by corals and coral-associated microorganisms from 2010 to March 2019, focusing on structure and the bioactivity of potent bioactive compounds with the half maximal inhibitory concentration $\left(\mathrm{IC}_{50}\right.$ ) (/half maximal effective concentration $\left(\mathrm{EC}_{50}\right) /$ median effective dose $\left(\mathrm{ED}_{50}\right) /$ growth inhibitory dose $50 \%$ of cells $\left(\mathrm{GI}_{50}\right)$ ) values less than $10 \mu \mathrm{M}(/ 10 \mu \mathrm{g} / \mathrm{mL})$.

\section{Bioactive Compounds from Coral}

\subsection{Anti-Inflammatory Compounds from Coral}

Inflammation is a defense response by organisms to hazardous stimuli such as allergens and/or injury to the tissues. In general, inflammation is indispensable in the protection of the body from pathogens and for the repair of damaged tissue. However, an exaggerated and persistent inflammatory response is also detrimental to human health. Uncontrolled inflammatory responses are also involved in the onset and maintenance of many severe disorders such as rheumatoid arthritis, asthma, diabetes, chronic inflammatory bowel diseases, neurodegenerative diseases, and cancer [47]. The high prevalence of inflammation requires the discovery and development of new anti-inflammatory drugs. Currently, the available approved anti-inflammatory drugs mainly consist of nonsteroidal anti-inflammatory drugs, glucocorticoids, and immunosuppressant drugs. However, these therapies are often not effective enough or are hampered by unwanted side effects [48]. Effective anti-inflammatory agents should be able to inhibit the development of inflammation without interfering in normal homeostasis. Thus, the discovery of safe and efficient new anti-inflammatory agents is still a great demand for scientists in academia and industry. 
The bioactive investigation of compounds isolated from corals has revealed coral-derived compounds as a potential source of anti-inflammatory drugs. Numerous anti-inflammatory compounds have been isolated from coral with different mechanisms (Supplementary Table S1), of which many compounds exhibit potent anti-inflammatory activities.

From the coral Lobophytum pauciflorum, seven new biscembranoids, lobophytones A-G, together with three known biscembranes, were isolated. Among them, lobophytone D (1) (Figure 1) showed potent inhibition toward lipopolysaccharide (LPS)-induced nitric oxide (NO) in mouse peritoneal macrophages with $\mathrm{IC}_{50}=4.70 \mu \mathrm{M}$ [49]. Chen et al. [50] isolated eight new eunicellin-based diterpenoids, hirsutalins A-H, from the coral Cladiella hirsuta. All compounds were evaluated for their anti-inflammatory activity based on inhibiting the upregulation of proinflammatory inducible nitric oxide synthase (iNOS) and cyclooxygenase-2 (COX-2) proteins of LPS-stimulated RAW264.7 macrophage cells. Notably, hirsutalins B (2) and D (3) (Figure 1) were found to potently reduce the levels of iNOS protein to $6.8 \% \pm 0.6 \%$ and $3.3 \% \pm 0.1 \%$, respectively, whereas hirsutalins $\mathrm{C}$ and $\mathrm{H}$ also effectively reduced the levels of iNOS protein to $43.6 \% \pm 8.7 \%$ and $32.3 \% \pm 6.1 \%$, respectively, relative to the control cells stimulated with LPS only. In addition, hirsutalin B also effectively reduced the level of COX-2 protein $(49.0 \% \pm 2.3 \%)$ [50]. Chemical investigation of the coral Lobophytum laevigatum also led to the isolation of four new cembranoids, laevigatols A-D, and six known metabolites. Interestingly, laevigatols A and B $(4,5)$, ximaolide F (6), and methyl tortuoate B (7) (Figure 1) showed dose-dependent inhibitory effects on the tumor necrosis factor $\alpha(\mathrm{TNF} \alpha$ )-induced (nuclear factor) NF- $\mathrm{kB}$ transcriptional activity in Hep-G2 cells, with $\mathrm{IC}_{50}=6.7-9.7 \mu \mathrm{M}$. Moreover, these compounds effectively inhibited the induction of COX-2 and iNOS mRNA dose-dependently [51].
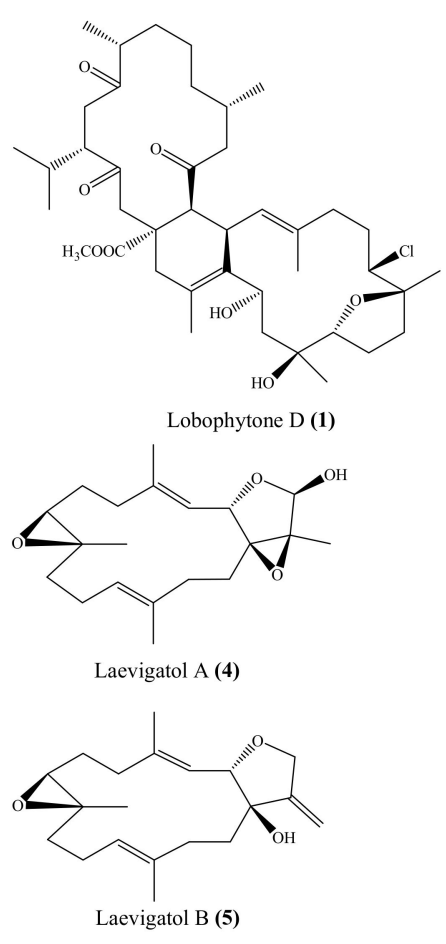

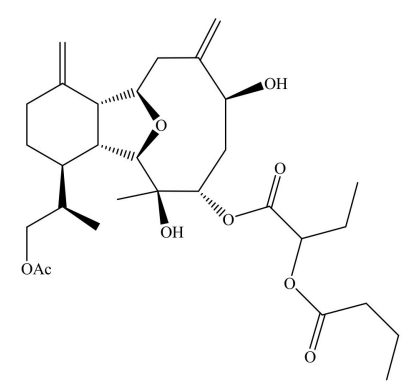

Hirsutalin B (2)

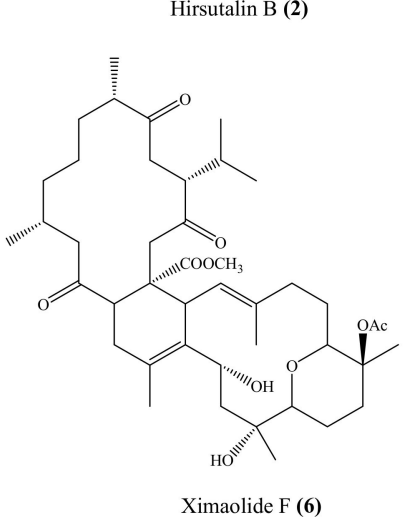

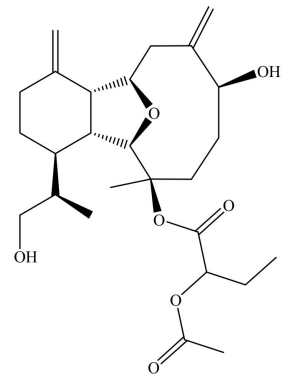

Hirsutalin D (3)

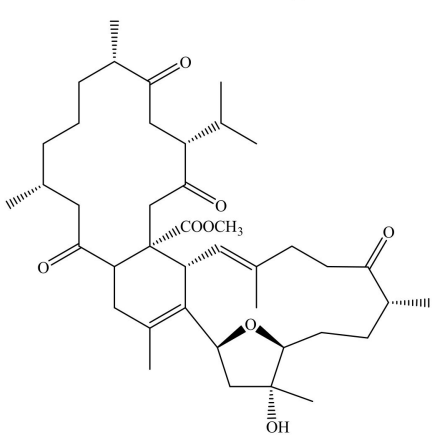

Methyl tortuoate B (7)

Figure 1. Chemical structures of 1-7.

Two new cembrane-type diterpenoids, triangulenes A and B, along with three known metabolites, were isolated from the coral Sinularia triangular. Among them, sinularin (8), dihydrosinularin (9), and (-)14-deoxycrassin (10) (Figure 2) could significantly reduce the levels of the iNOS protein to $1.2 \% \pm 0.3 \%, 5.1 \% \pm 1.6 \%$, and $0.9 \% \pm 0.7 \%$, respectively, at a concentration of $10 \mu \mathrm{M}$. At the same concentration, dihydrosinularin and (-)14-deoxycrassin markedly reduced the levels of COX-2 to $24.9 \% \pm 7.4 \%$ and $5.9 \% \pm 1.0 \%$, respectively [52]. In another study, Kao et al. [53] reported the 
isolation of five new cembrane-type diterpenoids, lobocrassins A-E, from the coral Lobophytum crissum. However, only lobocrassin B (11) (Figure 2) displayed significant inhibitory effects on the generation of the superoxide anion and the release of elastase by human neutrophils, with $\mathrm{IC}_{50}=4.8 \pm 0.7$ and $4.9 \pm 0.4 \mu \mathrm{g} / \mathrm{mL}(15.1 \pm 2.2$ and $15.4 \pm 1.3 \mu \mathrm{M})$. From the coral Paraminabea acronocephala, six new withanolides, paraminabeolides A-F, along with five known compounds, were also isolated. Compound paraminabeolides A-D were found to inhibit the accumulation of the proinflammatory iNOS protein, whereas compound minabeolides- $1,-2,-4$, and -5 could effectively reduce the expression of both the iNOS and COX-2 protein. Particularly, compound paraminabeolide A (12), paraminabeolide D (13), and minabeolide-5 (14) (Figure 2) potently reduced the levels of iNOS protein to $<10 \%$ at a concentration of $10 \mu \mathrm{M}$ [54]. Additionally, Hsu et al. [55] isolated eight new eunicellin-based diterpenoids, klymollins $\mathrm{A}-\mathrm{H}$, from the coral Klyxum molle. Biological tests indicated that compound klymollins $\mathrm{C}-\mathrm{H}$ displayed in vitro anti-inflammatory activity by inhibiting the expression of the iNOS protein, whereas compound klymollins $\mathrm{A}, \mathrm{B}, \mathrm{F}, \mathrm{G}$, and $\mathrm{H}$ could also reduce the accumulation of COX-2 protein in LPS-stimulated RAW264.7 macrophage cells. Especially, klymollin F (15) and klymollin G (16) (Figure 2) significantly reduced the levels of the iNOS and COX-2 proteins to $<10 \%$ at a concentration of $10 \mu \mathrm{M}$.

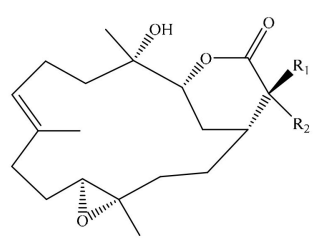

Sinularin: $\mathrm{R}_{1}=\mathrm{R}_{2}=\mathrm{CH}_{2}$ (8) Dihydrosinularin: $\mathrm{R}_{1}=\mathrm{CH}_{3}, \mathrm{R}_{2}=\mathrm{H}$ (9)

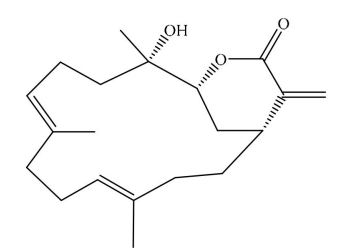

(-)14-Deoxycrassin (10)

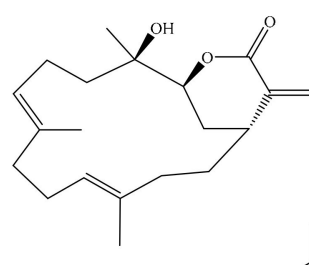

Lobocrassin B (11)

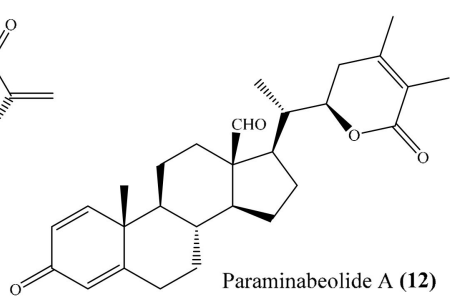

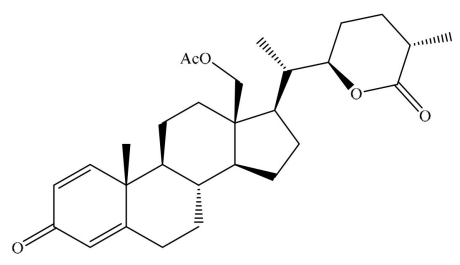

Minabeolide-5 (14)

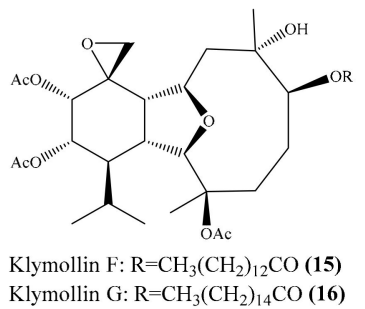

Klymollin $\mathrm{F}: \mathrm{R}=\mathrm{CH}_{3}\left(\mathrm{CH}_{2}\right)_{12} \mathrm{CO}(\mathbf{1 5})$
Klymollin $\mathrm{G}: \mathrm{R}=\mathrm{CH}_{3}\left(\mathrm{CH}_{2}\right)_{14} \mathrm{CO}(\mathbf{1 6})$

Figure 2. Chemical structures of 8-16.

A chemical study of the coral Sarcophyton crassocaule afforded seven new cembranoids, sarcocrassocolides F-L (17-23) (Figure 3). Interestingly, all of these compounds were found to display potent anti-inflammatory activity by reducing the expression of the iNOS protein to $<10 \%$ at a concentration of $10 \mu \mathrm{M}$. Furthermore, compound 20 was also found to effectively reduce the level of COX-2 protein to $<60 \%$ [56]. Chung et al. [57] reported the isolation of a new labdane-type diterpenoid, echinolabdane, and a new sterol, 6-epi-yonarasterol B, from the coral Echinomuricea sp. It is notable that both compounds displayed inhibitory effects on the generation of superoxide anions and the release of elastase by human neutrophils, of which 6-epi-yonarasterol B (24) (Figure 3) showed potent effects on the generation of superoxide anions and the release of elastase, with $\mathrm{IC}_{50}=2.98 \pm 0.29$ and $1.13 \pm 0.55 \mu \mathrm{g} / \mathrm{mL}(6.48 \pm 0.63$ and $2.46 \pm 1.20 \mu \mathrm{M})$. The activity of 24 was comparable to that of the positive control diphenylene iodonium (DPI), with $\mathrm{IC}_{50}=0.82 \pm 0.31 \mu \mathrm{g} / \mathrm{mL}(2.59 \pm 0.98 \mu \mathrm{M})$ for the generation of superoxide anions, and elastatinal, with $\mathrm{IC}_{50}=31.82 \pm 5.92 \mu \mathrm{g} / \mathrm{mL}(100.51 \pm 18.70 \mu \mathrm{M})$ for elastase release. Chemical examination of the coral Sarcophyton crassocaule also resulted in the isolation of three new cembranoids, sarcocrassocolides M-O (25-27) (Figure 3). Bioassay results revealed that all of these compounds potently inhibited the expression of the iNOS protein and effectively inhibited the expression of the COX-2 protein [58]. In another study, nine new steroids, sclerosteroids A-I, along with 18 known metabolites, were isolated from the coral Scleronephthya gracillimum. Among them, compound sclerosteroids A, B, and E displayed in vitro anti-inflammatory activity in LPS-stimulated 
RAW264.7 macrophage cells by inhibiting the expression of the iNOS protein and COX-2 protein. Especially, at a concentration of $10 \mu \mathrm{M}$, sclerosteroids A and B $(\mathbf{2 8}, \mathbf{2 9})$ (Figure 3) significantly reduced the levels of COX-2 protein to $5.4 \% \pm 1.3 \%$ and $6.7 \% \pm 3.5 \%$, respectively [59].

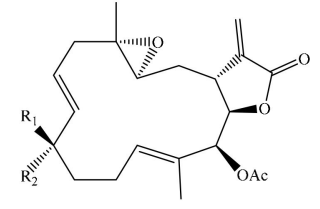

Sarcocrassocolide F: $\mathrm{R}_{1}=\mathrm{CH}_{3}, \mathrm{R}_{2}=\mathrm{OOH}$ (17) Sarcocrassocolide $\mathrm{G}: \mathrm{R}_{1}=\mathrm{OOH}, \mathrm{R}_{2}=\mathrm{CH}_{3}$ (18) Sarcocrassocolide $\mathrm{H}: \mathrm{R}_{1}=\mathrm{CH}_{3}, \mathrm{R}_{2}=\mathrm{OH}$ (19) Sarcocrassocolide I: $\mathrm{R}_{1}=\mathrm{OH}, \mathrm{R}_{2}=\mathrm{CH}_{3}$ (20)

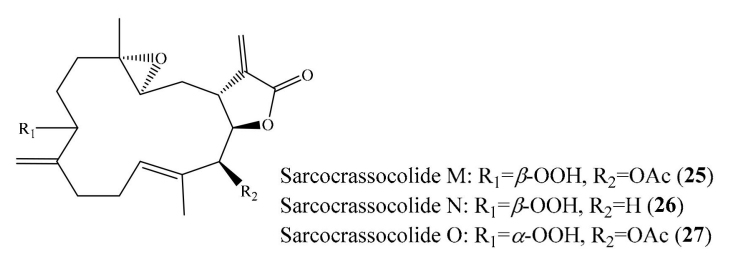

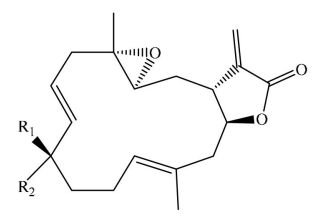

Sarcocrassocolide J: $\mathrm{R}_{1}=\mathrm{CH}_{3}, \mathrm{R}_{2}=\mathrm{OOH}$ (21) Sarcocrassocolide K: $\mathrm{R}_{1}=\mathrm{CH}_{3}, \mathrm{R}_{2}=\mathrm{OH}$ (22) Sarcocrassocolide M: $\mathrm{R}_{1}=\mathrm{OH}, \mathrm{R}_{2}=\mathrm{CH}_{3}$ (23)

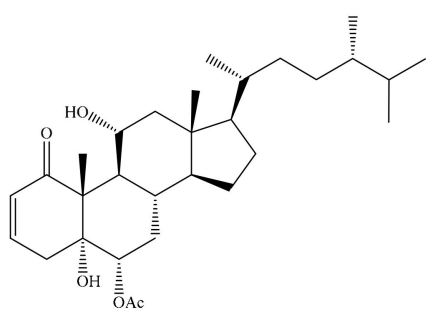

6-epi-Yonarasterol B (24)

Figure 3. Chemical structures of 17-29.

From the coral Cladiella sp., Chen et al. [60] yielded two new 6-hydroxyeunicellin diterpenoids, cladieunicellin G and 6-epi-cladieunicellin F, of which 6-epi-cladieunicellin F (30) (Figure 4) displayed significant inhibitory effects on the generation of the superoxide anion and the release of elastase by human neutrophils, with $\mathrm{IC}_{50}$ values of $6.57 \pm 0.85$ and $41.08 \pm 3.26 \mu \mathrm{g} / \mathrm{mL}$ $(20.40 \pm 2.64$ and $127.58 \pm 10.12 \mu \mathrm{M})$. DPI and elastatinal were used as positive controls, with $\mathrm{IC}_{50}=0.82 \pm 0.31 \mu \mathrm{g} / \mathrm{mL}(2.59 \pm 0.98 \mu \mathrm{M})$ for the generation of superoxide anions and with $\mathrm{IC}_{50}=31.82 \pm 5.92 \mu \mathrm{g} / \mathrm{mL}(100.51 \pm 18.70 \mu \mathrm{M})$ for elastase release. Yang et al. [61] reported the isolation of five new cembrane diterpenoids, sinuflexibilins A-E, along with nine other known diterpenoids from the coral Sinularia sp. However, bioassays indicated that only the compound flexibilide (31) (Figure 4) exhibited significant inhibitory activity of NF- $\mathrm{kB}$ activation, with $\mathrm{IC}_{50}=5.30 \mu \mathrm{g} / \mathrm{mL}(15.87 \mu \mathrm{M})$. From the coral Cladiella krempfi, five new eunicellin-based diterpenoids, krempfielins E-I, together with seven known compounds, were isolated. At a concentration of $10 \mu \mathrm{M}$, three compounds (krempfielin $\mathrm{F}$, 6-methyl ether of litophynol B (32) (Figure 4), and 6-acetoxy litophynin E could significantly inhibit the accumulation of the proinflammatory iNOS protein. Among them, 6-methyl ether of litophynol B (32) potently reduced the levels of iNOS protein to $6.4 \% \pm 0.8 \%$. In addition, 6 -methyl ether of litophynol B (32) and litophynin F could also significantly reduce the expression of COX-2 protein in LPS-stimulated RAW264.7 macrophage cells [62]. Thao et al. [63] isolated two new norditerpenoids along with five other known norditerpenoids from the coral Sinularia maxima. Among them, compound 13-epi-scabrolide C (33) (Figure 4) potently inhibited interleukin (IL)-12 and IL-6 production in LPS-stimulated bone marrow-derived dendritic cells (BMDCs), with $\mathrm{IC}_{50}$ values of $5.30 \pm 0.21$ and $13.12 \pm 0.64 \mu \mathrm{M}$, respectively, whereas compound scabrolide A also exhibited moderate inhibitory activity against IL-12 and IL-6 production, with $\mathrm{IC}_{50}$ values of $23.52 \pm 1.37$ and $69.85 \pm 4.11 \mu \mathrm{M}$, respectively. The positive control SB203580, an inhibitor of cytokine-suppressive binding protein/p38 kinase, inhibited IL-12 and IL-6, with $\mathrm{IC}_{50}$ of $5.67 \pm 0.24$ and $3.56 \pm 0.11 \mu \mathrm{M}$, respectively. Chemical investigation of the coral Lobophytum crassum led to the isolation of one new compound, crassumsterol, along with three known compounds. Interestingly, $(22 R, 23 R, 24 R)-5 \alpha, 8 \alpha$-epidioxy-22,23-methylene-24-methylcholest-6-en-3 $\beta$-ol (34) and ergosterol peroxide (35) (Figure 4) had potent inhibitory effects on TNF $\alpha$-induced NF-kB transcriptional activation in Hep-G2 cells, with $\mathrm{IC}_{50}$ values of 3.90 and $7.05 \mu \mathrm{M}$, respectively [64]. Yin et al. [65] afforded six new casbane diterpenoids, sinularcasbanes A-F, along with six known analogues, from the coral Sinularia sp. Among them, compound sinularcasbanes B and E $(36,37)$ 
(Figure 4) showed potent inhibition of lipopolysaccharide LPS-induced NO production in mouse peritoneal macrophages, with $\mathrm{IC}_{50}$ values of 8.3 and $5.4 \mu \mathrm{M}$, respectively.

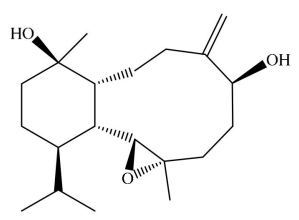

6-epi-Cladieunicellin F (30)

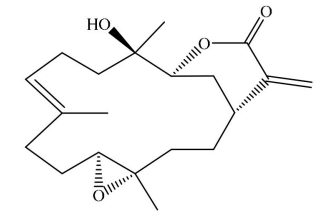

Flexibilide (31)

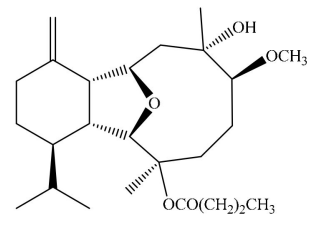

6-methyl ether of Litophynol B (32)

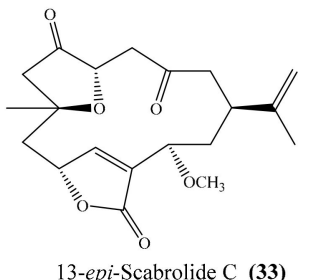

13-epi-Scabrolide C (33)
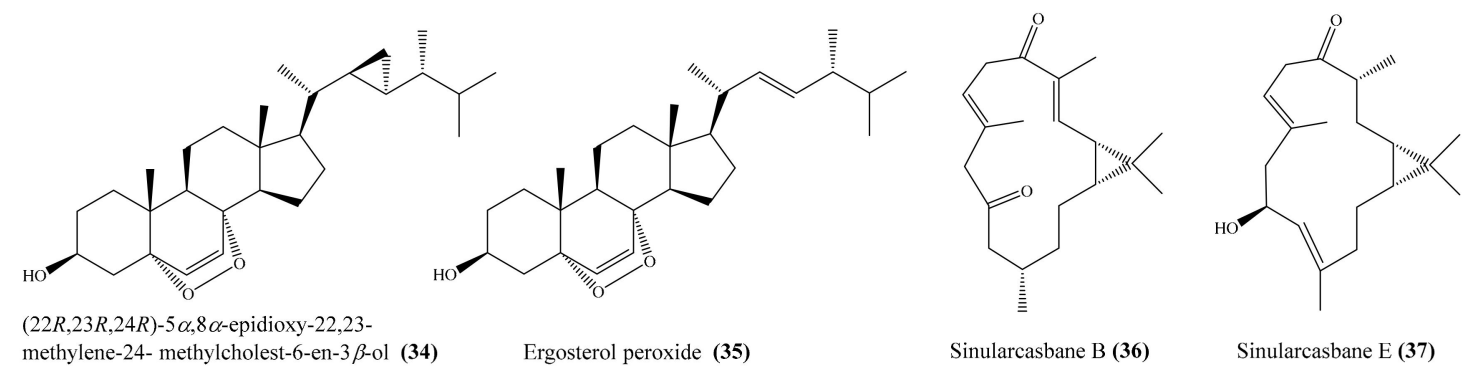

Sinularcasbane E (37)

Figure 4. Chemical structures of 30-37.

Chemical examination of the coral Klyxum molle yielded 11 new eunicellin-based diterpenoids, klymollins I-S. Among them, compound klymollin M (38) (Figure 5) was the first eunicellin-based metabolite bearing a phenyl group and displayed significant inhibition of both superoxide anion generation and elastase release in $\mathrm{N}$-formyl-L-methionyl-L-leucyl-Lphenylalanine/cytochalasin B (fMLP/ CB)-induced human neutrophils, with $\mathrm{IC}_{50}$ values of $3.13 \pm 0.39 \mu \mathrm{M}$ and $2.92 \pm 0.27 \mu \mathrm{M}$, respectively [66]. From the soft coral Cladiella hirsuta, Chen et al. [67] obtained five new eunicellin-based diterpenoids, hirsutalins I-M. Interestingly, compound hirsutalin K (39) (Figure 5) was found to possess the strongest NO inhibitory activity, with an $\mathrm{IC}_{50}$ value of $9.8 \mu \mathrm{g} / \mathrm{mL}(22.5 \mu \mathrm{M})$, while the positive control curcumin exhibited NO inhibitory activity, with an $\mathrm{IC}_{50}$ value of $10 \mu \mathrm{g} / \mathrm{mL}$ $(27.1 \mu \mathrm{M})$. Furthermore, 39 effectively reduced the expression of iNOS protein in the same cells. From another coral, Lobophytum crassum, four new cembranoid diterpenes, lobocrasols A-D, were isolated. Bioassays showed that lobocrasols A and B $(40,41)$ (Figure 5) potently inhibited TNF $\alpha$-induced NF- $\kappa \mathrm{B}$ transcriptional activity in HepG2 cells in a dose-dependent manner, with $\mathrm{IC}_{50}$ values of $6.30 \pm 0.42$ and $6.63 \pm 0.11 \mu \mathrm{M}$, respectively. Besides, the transcriptional inhibition of these compounds was confirmed by a decrease in COX-2 and iNOS expression levels in HepG2 cells [68]. From the same coral species, Cuong et al. [69] isolated four new cembranoid diterpenes, crassumols D-G, along with five known compounds. Interestingly, compounds $(1 R, 4 R, 2 E, 7 E, 11 E)$-cembra-2,7,11-trien-4-ol (42) and crassumol E (43) (Figure 5) exhibited a potent inhibitory effect on TNF $\alpha$-induced NF- $\kappa \mathrm{B}$ transcriptional activation in HepG2 cells, with $\mathrm{IC}_{50}$ values of $1.65 \pm 0.2$ and $9.23 \pm 1.66 \mu \mathrm{M}$, respectively. Furthermore, compound 42 effectively inhibited the expression of COX-2 and iNOS protein in a dose-dependent manner, indicating that this compound reduced the transcription of these genes. From the coral Sarcophyton pauciplicatum, a new steroid, sarcopanol A, along with two known ones, were isolated. Interestingly, compound sarcopanol A (44) (Figure 5) exhibited significant inhibitory effects on $\mathrm{TNF} \alpha$-induced NF- $\kappa \mathrm{B}$ transcriptional activity, with an $\mathrm{EC}_{50}$ value of $8.27 \pm 3.28 \mu \mathrm{M}$, whereas compounds (24S)-ergost-1b,3b,5a,6b-tetraol-25-monoacetate and (24S)-ergost-25-ene-1 $\beta, 3 \beta, 5 \alpha, 6 \beta$-tetraol exhibited moderate effects, with $\mathrm{EC}_{50}$ values of $26.07 \pm 5.59$ and $50 \mu \mathrm{M}$, respectively. The positive control apigenin exhibited activity, with $\mathrm{EC}_{50}=4.51 \pm 0.53 \mu \mathrm{M}$. Furthermore, the transcriptional inhibition of these compounds was confirmed by a decrease in cyclooxygenase-2 (COX-2), inducible nitric oxide synthase (iNOS), and intercellular adhesion molecule-1 (ICAM-1) gene expression levels in HaCaT cells [70]. From the coral Cladiella krempfi, Lee et al. [71] afforded three new eunicellin-type diterpenoids, 
krempfielins N-P. Compound krempfielin N (45) (Figure 5) exhibited potent activity in inhibiting elastase release in $\mathrm{fMLP} / \mathrm{CB}$-induced human neutrophils, with $\mathrm{IC}_{50}$ of $4.94 \pm 1.68 \mu \mathrm{M}$, where the remaining two compounds showed weak activity in inhibiting elastase release, with $\mathrm{IC}_{50}>10 \mu \mathrm{M}$. The activity of 45 was comparable to that of the positive control LY294002 (a phosphatidylinositol-3-kinase inhibitor), with $\mathrm{IC}_{50}$ values of $4.12 \pm 0.92 \mu \mathrm{M}$. Additionally, compound krempfielin P inhibited $23.32 \% \pm 5.88 \%$ generation of the superoxide anion.

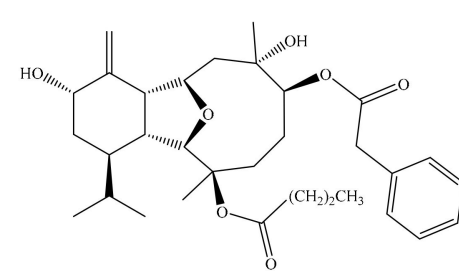

Klymollin M (38)

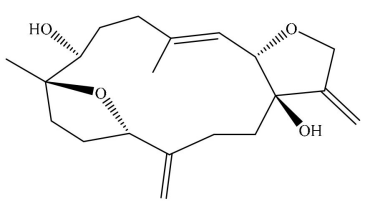

Crassumol E (43)

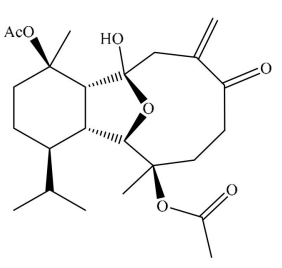

Hirsutalin K (39)

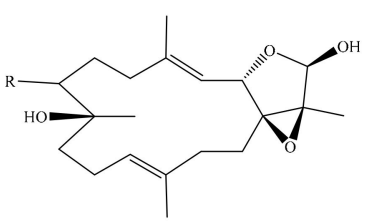

Lobocrasol A: $\mathrm{R}=\beta-\mathrm{OH}(\mathbf{4 0})$ Lobocrasol B: $\mathrm{R}=\alpha-\mathrm{OH}$ (41)

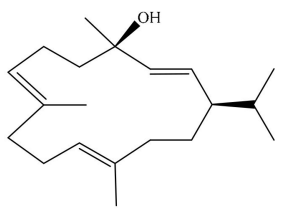

$(1 R, 4 R, 2 E, 7 E, 11 E)-$ Cembra-2,7,11-trien-4-ol (42)
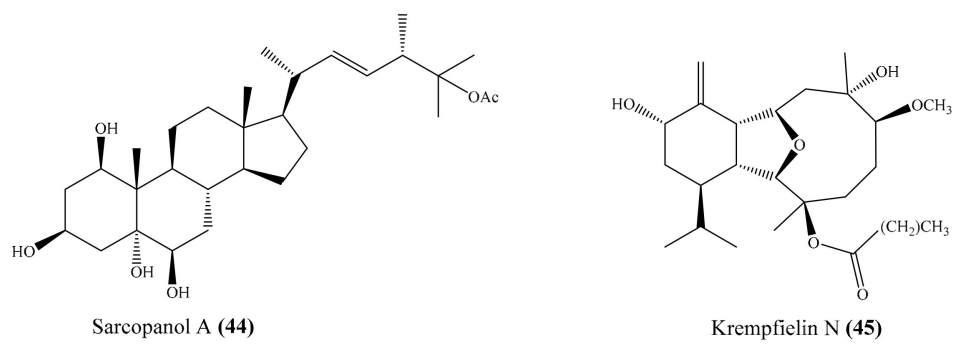

Figure 5. Chemical structures of 38-45.

Chemical investigation of the coral Sarcophyton crassocaule afforded three new cembranoids, sarcocrassocolides P-R (46-48), and four known compound crassocolides: A, B, D, and E (49-52) (Figure 6). All of these compounds displayed potent in vitro anti-inflammatory activity in lipopolysaccharide (LPS)-stimulated RAW264.7 macrophage cells by inhibiting the expression of iNOS protein to $3.5 \%$ at a concentration of $10 \mu \mathrm{M}$, whereas compounds 47,49 , and 52 also showed moderate activity in reducing the accumulation of COX-2 protein at the same concentration [72]. From the coral Cladiella hirsuta, two new pregnane glycosides, hirsutosterosides A and B, along with two new atocopherylhydroquinone glycosides, cladophenol glycosides $\mathrm{A}$ and $\mathrm{B}$, were isolated. In addition, a new steroidal glycoside, lobatasteroside A, along with six known steroids, were isolated from the coral Sinularia nanolobata. Compound hirsutosteroside A (53) (Figure 6) did not exhibit inhibition activity toward superoxide anion generation $\left(\mathrm{IC}_{50}>10 \mu \mathrm{M}\right)$ but potently inhibited $\mathrm{fMLP} / \mathrm{CB}$-induced elastase release, with $\mathrm{IC}_{50}$ values of $4.1 \pm 0.1 \mu \mathrm{M}$. Compound $5 \beta, 6 \beta$-epoxy-3 $\beta, 11$-dihydroxy-24-methylene-9,11-secocholestan-9-one showed moderate activities toward superoxide anion generation and elastase release, with $\mathrm{IC}_{50}$ values of $18.6 \pm 1.5$ and $10.1 \pm 0.8 \mu \mathrm{M}$, respectively, while compound crassarosterol A (54) (Figure 6) significantly inhibited superoxide anion generation and elastase release, with $\mathrm{IC}_{50}$ values of $6.6 \pm 0.6$ and $2.9 \pm 0.5 \mu \mathrm{M}$, respectively [73]. LY294002 was used as a positive control for the inhibition of superoxide anion generation and elastase release, with $\mathrm{IC}_{50}$ values of $0.6 \pm 0.1$ and $1.2 \pm 0.3 \mu \mathrm{g} / \mathrm{mL}(1.95 \pm 0.33$ and $3.90 \pm 0.98 \mu \mathrm{M})$, respectively. 


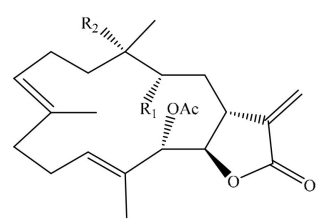

Parcocrassocolide $\mathrm{P}: \mathrm{R}_{1}=\mathrm{OH}, \mathrm{R}_{2}=\mathrm{OAc}$ (46) Parcocrassocolide Q: $\mathrm{R}_{1}=\mathrm{OAc}, \mathrm{R}_{2}=\mathrm{OH}$ (47)

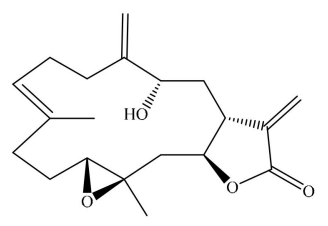

Parcocrassocolide R (48)

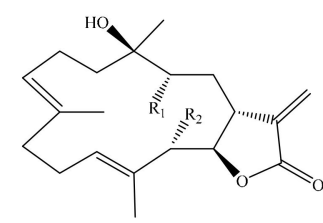

Crassocolide A: $\mathrm{R}_{1}=\mathrm{OH}, \mathrm{R}_{2}=\mathrm{OAc}$ (49) Crassocolide $\mathrm{B}$ : $\mathrm{R}_{1}=\mathrm{OAc}, \mathrm{R}_{2}=\mathrm{OAc}(\mathbf{5 0})$ Crassocolide D: $\mathrm{R}_{1}=\mathrm{OH}, \mathrm{R}_{2}=\mathrm{H}(\mathbf{5 1})$

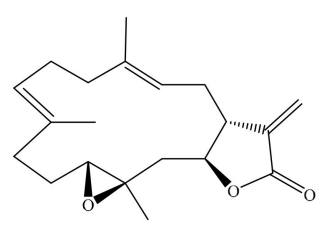

Crassocolide E (52)

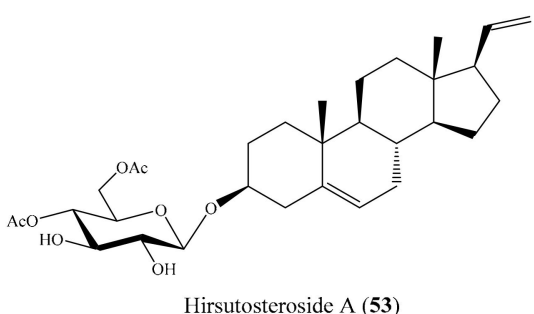

Hirsutosteroside A (53)

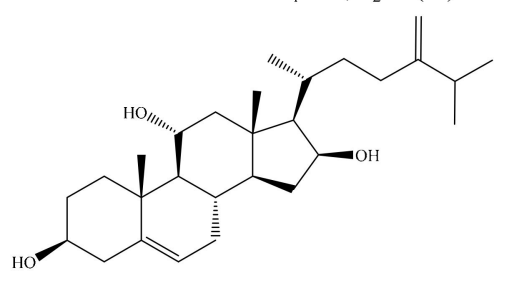

Crassarosterol A (54)

Figure 6. Chemical structure of $46-54$.

Chemical investigation of the coral Sinularia erecta yielded four new isoprenoids and four known compounds. Biological tests indicated that three compounds, sinulerectols A and B $(55,56)$ and (Z)-N-[2-(4 hydroxyphenyl)ethyl]-3-methyldodec-2-enamide (57) (Figure 7), displayed potent anti-inflammatory activity in $\mathrm{fMLP} / \mathrm{CB}$-stimulated human neutrophils, with $\mathrm{IC}_{50}$ values from $0.9 \pm 0.1$ to $8.5 \pm 0.3 \mu \mathrm{M}$ [74]. Tsai et al. [75] reported the isolation of six new steroids, klyflaccisteroids A-E; a new 9,11-secogorgosteroid, klyflaccisteroid F; two known steroids; and a known eunicellin-based diterpenoid from the coral Klyxum flaccidum. It is notable that compounds klyflaccisteroid C (58), klyflaccisteroid F (59), and 3ß,11-dihydroxy-9,11-secogorgost-5-en-9-one (60) (Figure 7) exhibited potent anti-inflammatory activity in inhibiting both superoxide generation and elastase release in $\mathrm{fMLP} / \mathrm{CB}$-induced neutrophils, with $\mathrm{IC}_{50}$ values from $0.34 \pm 0.01$ to $4.78 \pm 0.87 \mu \mathrm{M}$, whereas klyflaccisteroid E (61) (Figure 7) only exhibited potent activity in inhibiting elastase release, with an $\mathrm{IC}_{50}$ value of $5.37 \pm 0.20 \mu \mathrm{M}$. From another coral, Sarcophyton glaucum, two novel biscembranes, glaucumolides A and B $(62,63)$ (Figure 7), were obtained. Both compounds displayed strong inhibition of superoxide anion generation and elastase release in $\mathrm{fMLP} / \mathrm{CB}$-induced human neutrophils, with $\mathrm{IC}_{50}$ values from $2.79 \pm 0.32$ to $3.97 \pm 0.10 \mu \mathrm{M}$. Furthermore, these compounds significantly inhibited the accumulation of the proinflammatory inducible nitric oxide synthase protein and the expression of COX-2 protein in lipopolysaccharide-stimulated RAW264.7 macrophage cells [76]. 

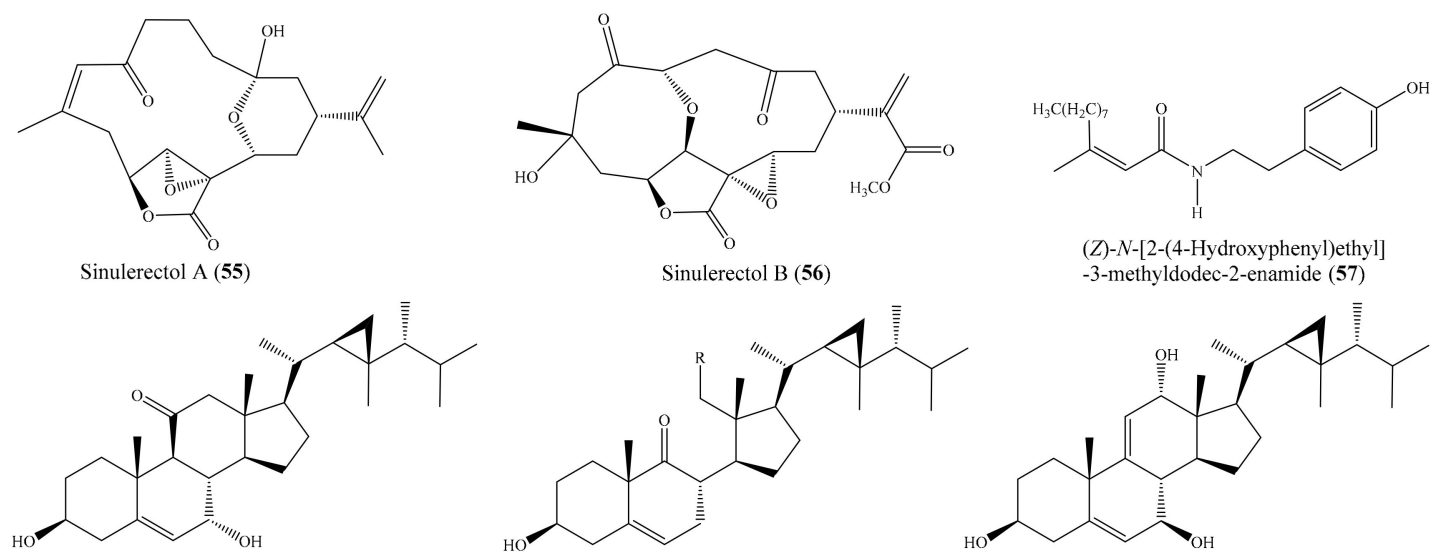

Klyflaccisteroid C (58)

Klyflaccisteroid F: $\mathrm{R}=\mathrm{COOH}(\mathbf{5 9})$

$3 \beta, 11$-Dihydroxy-9,11-secogorgost-5-en-9-one: $\mathrm{R}=\mathrm{CH}_{2} \mathrm{OH}(\mathbf{6 0})$

Klyflaccisteroid E (61)

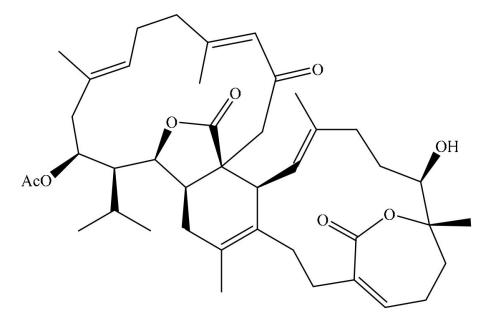

Glaucumolide A (62)

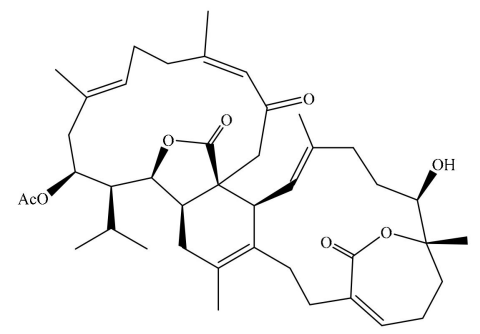

Glaucumolide B (63)

Figure 7. Chemical structures of 55-63.

From the coral Klyxum flaccidum, three new steroids, klyflaccisteroids K-M, were isolated. Compound klyflaccisteroid K (64) (Figure 8) was found to display significant anti-inflammatory activity in suppressing superoxide anion generation and elastase release, with $\mathrm{IC}_{50}$ values of $5.83 \pm 0.62$ and $1.55 \pm 0.21 \mu \mathrm{M}$, respectively, whereas compound klyflaccisteroid M (65) (Figure 8) was also found to show notable anti-inflammatory activity toward elastase release, with an $\mathrm{IC}_{50}$ value of $5.84 \pm 0.33 \mu \mathrm{M}$ [77]. A chemical study of the coral Pinnigorgia sp. resulted in the isolation of three new 9,11-secosterols, pinnisterols A-C, of which two compounds (pinnisterols $A$ and $C$ (66 and 67) (Figure 8) displayed remarkable inhibitory effects on the generation of superoxide anions and the release of elastase in human neutrophils, with $\mathrm{IC}_{50}$ values from 2.33 to $3.32 \mu \mathrm{M}$ [78]. From the coral Umbellulifera petasites, Huang et al. [79] reported the isolation of three new steroids, petasitosterones A-C, along with eight known steroids. The compound petasitosterone B (68) (Figure 8) effectively reduced NO production to $16.9 \%$ at $10 \mu \mathrm{g} / \mathrm{mL}(22.7 \mu \mathrm{M})$, whereas $5 \alpha$-pregna-1,20-dien-3-one (69) (Figure 8) showed potent inhibition of NO production to $0.3 \%$ at the same concentration $(10 \mu \mathrm{g} / \mathrm{mL}$ $(33.6 \mu \mathrm{M}))$. Interestingly, both of these compounds exhibited better inhibitory activity than the positive control aminoguanidine at the same concentration $(10 \mu \mathrm{g} / \mathrm{mL}(135.0 \mu \mathrm{M}))$. Furthermore, compound 68 and petasitosterone $C(70)$ (Figure 8) showed potent inhibition toward superoxide anion generation, with $\mathrm{IC}_{50}$ values of $4.43 \pm 0.23$ and $2.76 \pm 0.92 \mu \mathrm{M}$, respectively, whereas compound $5 \alpha$-pregna-20-en-3-one (71) (Figure 8) significantly inhibited fMLP/CB-induced elastase release, with an $\mathrm{IC}_{50}$ value of $6.80 \pm 0.18 \mu \mathrm{M}$. A chemical investigation of the coral Klyxum flaccidum afforded four new steroids, klyflaccisteroids G-J. Interestingly, compound klyflaccisteroid J (72) (Figure 8) was found to display significant anti-inflammatory activity in suppressing superoxide anion generation and elastase release, with $\mathrm{IC}_{50}$ values of $5.64 \pm 0.41$ and $4.40 \pm 0.19 \mu \mathrm{M}$, respectively, whereas compound klyflaccisteroids $\mathrm{G}$ and $\mathrm{H}$ showed weak inhibition of superoxide anion generation and elastase release, with $\mathrm{IC}_{50}>10 \mu \mathrm{M}$. Notably, the anti-inflammatory activity of compound $\mathbf{7 2}$ toward suppressing superoxide anion generation and elastase release was comparable to that of the positive control LY294002 ( $\mathrm{IC}_{50}=3.65 \pm 1.14$ and $5.15 \pm 1.17 \mu \mathrm{M}$ for superoxide anion and elastase, respectively) [80]. 


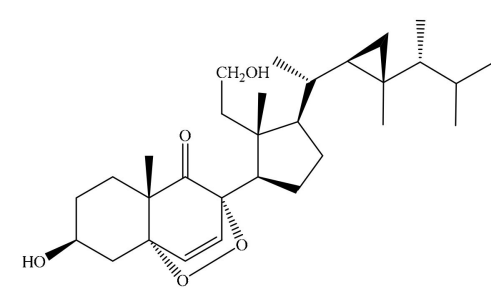

Klyflaccisteroid K (64)
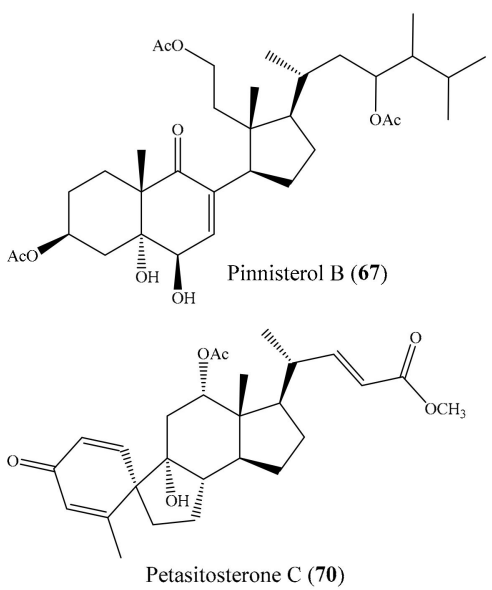
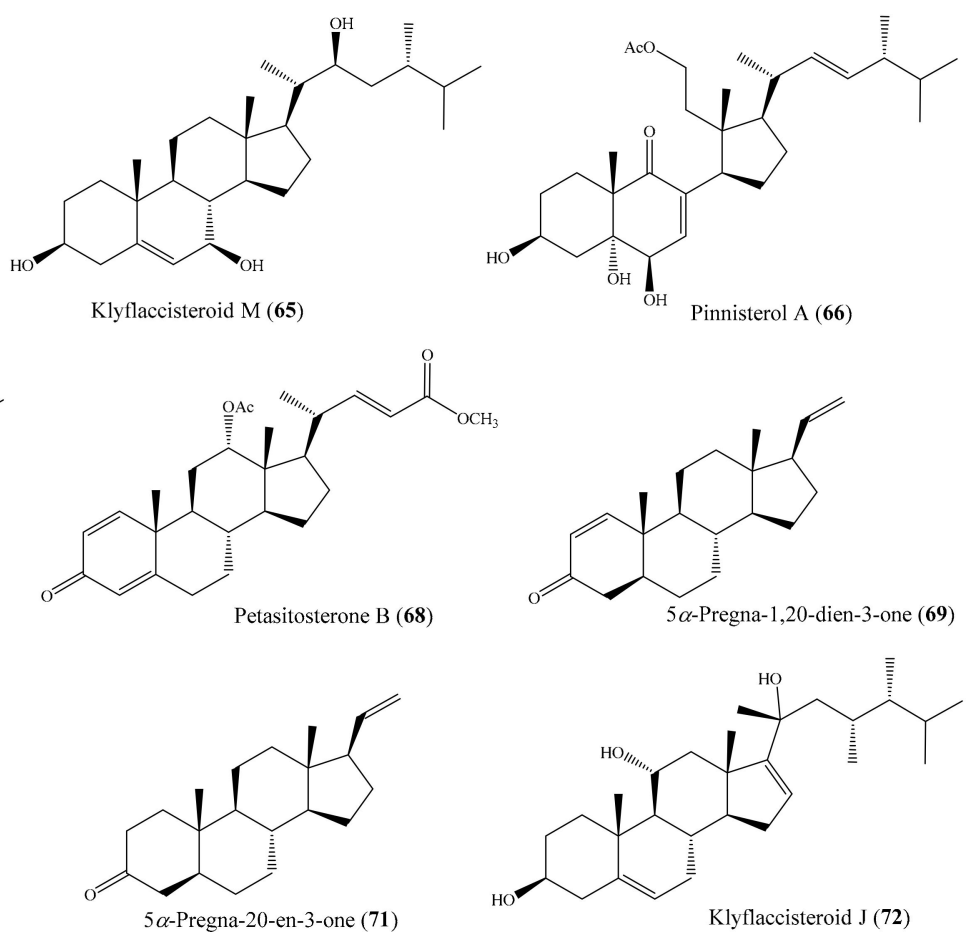

Figure 8. Chemical structures of 64-72.

Ten new cembrane-based diterpenes, locrassumins A-G, (-)-laevigatol B, (-)-isosarcophine, and $(-)-7 R, 8 S$-dihydroxydeepoxysarcophytoxide, together with eight known analogues, were isolated from the coral Lobophytum crassum. Compound sarcophytonolide O (73) (Figure 9) exhibited significant inhibition against LPS-induced NO production, with an $\mathrm{IC}_{50}$ value of $8 \mu \mathrm{M}$, whereas compounds locrassumin A, locrassumin G, ent-sarcophine, and ketoemblide also displayed effective inhibition against LPS-induced NO production, with $\mathrm{IC}_{50}$ values of $12-24 \mu \mathrm{M}$ [81]. In another investigation, Chang et al. [82] yielded three novel 9,11-secosterols with a rare carbon skeleton arrangement, pinnigorgiols A-C (74-76) (Figure 9), from the coral Pinnigorgia sp. Interestingly, all three compounds displayed remarkable inhibition effects on the generation of superoxide anions and the release of elastase by human neutrophils, with $\mathrm{IC}_{50}$ values from $2.7-5.3 \mu \mathrm{M}$. Chemical investigation of the coral Sinularia brassica obtained five new withanolides, sinubrasolides $\mathrm{H}-\mathrm{L}$, together with the known compound sinubrasolide A. Although all six isolated compounds displayed inhibitory effects against superoxide anion generation and elastase release in fMLP/CB-stimulated cells, only compound sinubrasolide A (77) (Figure 9) showed potent inhibitory effects against superoxide anion generation and elastase release, with $\mathrm{IC}_{50}$ values of $3.5 \pm 0.9$ and $1.4 \pm 0.1 \mu \mathrm{M}$, respectively [83]. From the coral Sinularia flexibilis, three new flexibilide-like cembranoids, xidaosinularides A-C, along with six known flexibilides, were obtained. Among them, compounds 11-epi-sinulariolide acetate (78), sinulariolide (79), and flexilarin B (80) (Figure 9) exhibited strong anti-inflammatory effects through the accumulation of proinflammatory TNF- $\alpha$, with $\mathrm{IC}_{50}$ values of $2.7,4.7$, and $4.2 \mu \mathrm{M}$, respectively. However, it is of interest that compound 5-dehydrosinulariolide, with a carbonyl group at the C-5 position, displayed no activity $\left(\mathrm{IC}_{50}>50 \mu \mathrm{M}\right)$, whereas $\mathbf{7 8}$ and $\mathbf{7 9}$, whose structures only differed from that of 5-dehydrosinulariolide in the C-5 position, exhibited significant anti-inflammatory activity, suggesting that the carbonyl at the C-5 position could reduce the inhibition of the accumulation of proinflammatory TNF- $\alpha$ [84]. 


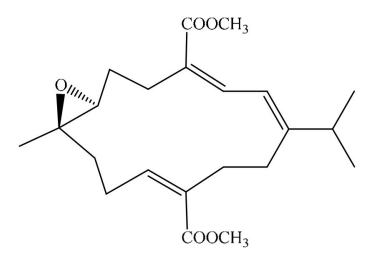

Sarcophytonolide $\mathrm{O}(\mathbf{7 3})$
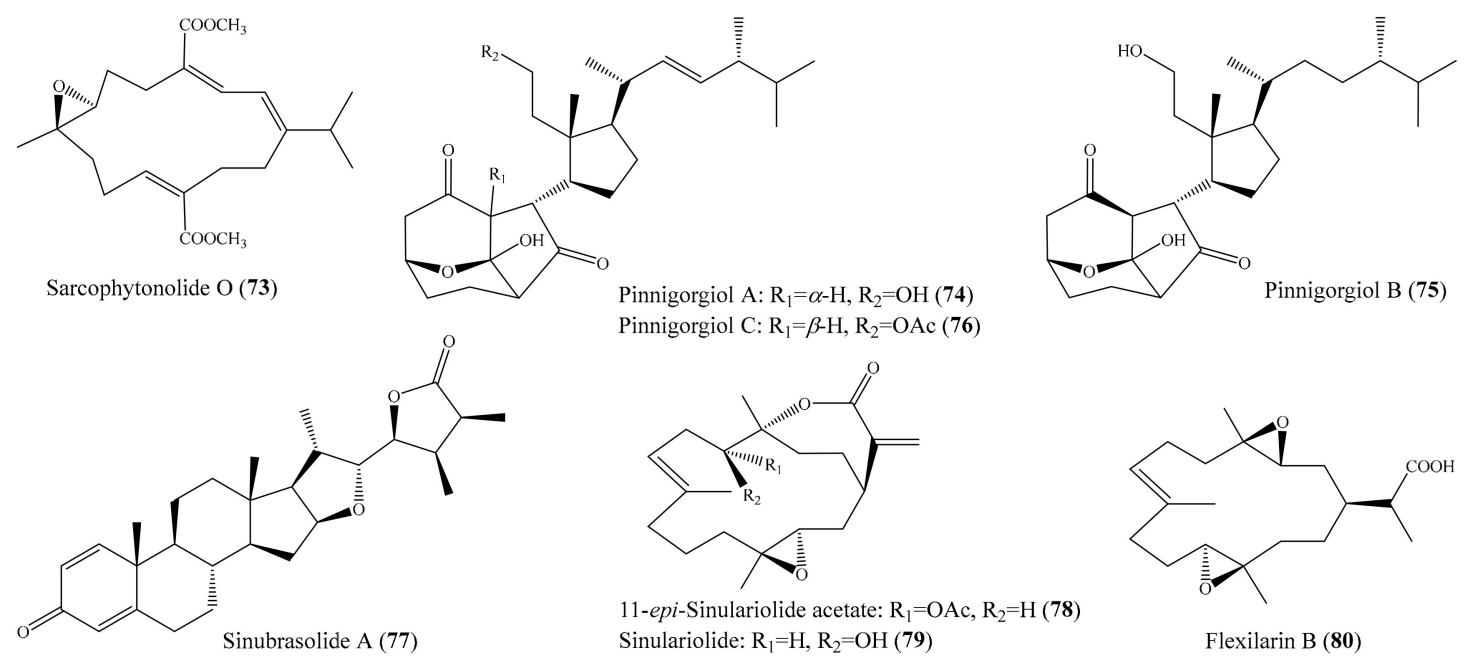

Pinnigorgiol $\mathrm{C}: \mathrm{R}_{1}=\beta-\mathrm{H}, \mathrm{R}_{2}=\mathrm{OAc}(76)$
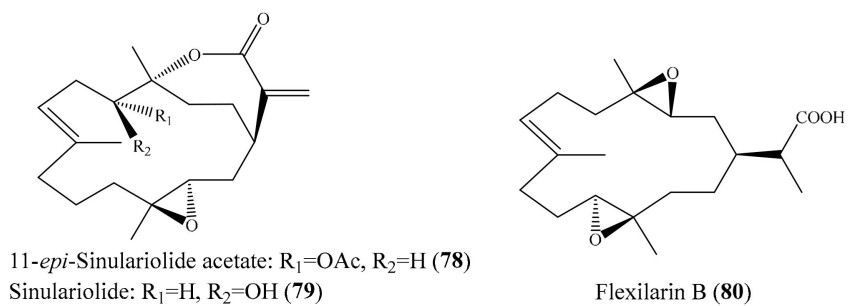

Figure 9. Chemical structures of $\mathbf{6 6 - 8 0 .}$

\subsection{Cytotoxic Compounds from Coral}

Cancers are known as "a group of diseases characterized by the uncontrolled growth and spread of abnormal cell" and are a major cause of death worldwide. Currently, the main treatments for cancer involve the development of surgical procedures, the use of radiotherapy and/or chemotherapeutic agents, as well as a combination of chemotherapy and hormone therapy with immunotherapy $[85,86]$. Despite their severe toxicity, chemotherapy, radiotherapy, and immunotherapy are the gold standard approaches to the treatment of cancer. As they are less toxic, the discovery and use of natural products is being tried as an alternative in the treatment of cancer [87]. It is noted that several factors should be accounted for in the development of effective therapies for cancer. One of the main problems that needs to be of concern in cancer treatment is to minimize the side effects of the therapies [88]. Another problem that needs to be considered is the development of resistant phenotypes, which include cytotoxic resistance to proapoptotic stimuli and/or anticancer agents. Despite all attempts to prevent oncological disorders and develop new therapies, cancer remains a serious public health problem. Thus, there is increasing attention on strategies to effectively control tumors, prolong survival, minimize chemotherapy side effects, and improve the quality of life for patients [89]. From this point of view, a demand for the discovery of safe and effective new cytotoxic agents for the treatment of cancer is needed.

Apart from anti-inflammatory activity, many cytotoxic compounds have been produced by coral (Supplementary Table S2), of which many compounds show potent cytotoxicity against different cancer cell lines, with $\mathrm{IC}_{50}$ values less than $10 \mu \mathrm{M}$ or $10 \mu \mathrm{g} / \mathrm{mL}$.

Chemical study of the coral Lobophytum sp. resulted in the isolation of one new squalene derivative, lobophytene, along with three cembranoid diterpenes and two sterols. The compounds lobophytene (81) and (1S,2S,3E,7E,11E)-3,7,11,15-cembratetraen-17,2-olide (82) (Figure 10) showed significant cytotoxic activities against lung (A549) and colon (HT-29) cell lines, with IC $_{50}$ values from 1.8 to $8.2 \mu \mathrm{M}$. The cytotoxic activities of $\mathbf{8 1}$ and $\mathbf{8 2}$ were comparable to those of the positive control mitoxantrone. Mitoxantrone showed cytotoxicity against the A549 and HT-29 cell lines, with $\mathrm{IC}_{50}$ values of 6.1 and $6.5 \mu \mathrm{M}$, respectively [90]. From Lobophytum compactum, two new diterpenes, lobocompactols $\mathrm{A}$ and $\mathrm{B}$, along with five known compounds, were isolated. Subsequent bioassays indicated that compound 3 3,11 -dihydroxy-24-methylene-9,11-secocholestan-5-en-9-one (83) (Figure 10) exhibited strong cytotoxic activity against the A549 cell line, with an $\mathrm{IC}_{50}$ of $4.97 \pm 0.06 \mu \mathrm{M}$, whereas compounds lobatrienolide, lobatriene, and (24S)-ergostane- $3 \beta, 5 \alpha, 6 \beta, 25$-tetraol 25-monoacetate showed moderate activity against the A549 cell line. Furthermore, all of these compounds exhibited moderate cytotoxicity against the HL-60 cell line. Interestingly, the cytotoxic activity of $\mathbf{8 3}$ against the A549 cells was comparable to that of the positive control mitoxantrone $\left(\mathrm{IC}_{50}=7.83 \pm 0.04 \mu \mathrm{M}\right)$ [91]. Kao et al. [53] 
reported the isolation of five new cembrane-type diterpenoids from the coral Lobophytum crissum (see Section 2.1). Interestingly, four compounds, lobocrassins A-D exhibited cytotoxicity toward different tumor cell lines (K562, CCRF-CEM, Molt4, HepG2, Huh7). Notably, compound lobocrassin A (84) (Figure 10) displayed strong cytotoxicity toward the CCRF-CEM cell line, with an $\mathrm{IC}_{50}$ value of $5.33 \mu \mathrm{g} / \mathrm{mL}(15.1 \mu \mathrm{M})$; compound lobocrassin B (11) (Figure 2) displayed strong cytotoxicity toward all of the above cell lines, with $\mathrm{IC}_{50}$ values from 0.34 to $8.17 \mu \mathrm{g} / \mathrm{mL}(1.07$ to $25.7 \mu \mathrm{M})$; whereas lobocrassin C (85) (Figure 10) displayed strong cytotoxicity toward the MOLT-4 cell line, with an IC 50 value of $9.51 \mu \mathrm{g} / \mathrm{mL}(32.8 \mu \mathrm{M})$. Doxorubicin was used as a reference compound, with $\mathrm{IC}_{50}$ values ranging from 0.07 to $0.71 \mu \mathrm{g} / \mathrm{mL}(0.13$ to $1.31 \mu \mathrm{M})$.
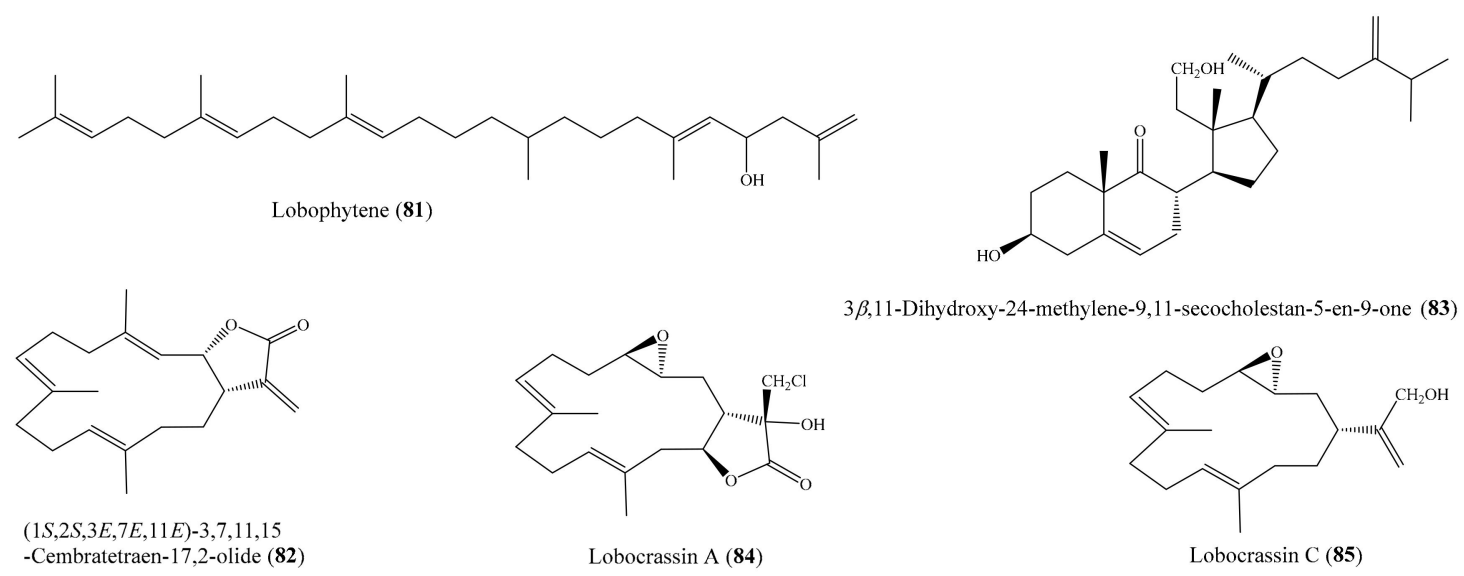

3ß,11-Dihydroxy-24-methylene-9,11-secocholestan-5-en-9-one (83)

Figure 10. Chemical structures of 81-85.

In another study, six new withanolides, along with five known compounds, were obtained from the coral Paraminabea acronocephala (see Section 2.1). Notably, the compounds paraminabeolide A (12) (Figure 2) and minabeolide-1 (86) (Figure 11) were found to exhibit remarkable cytotoxic activity toward HepG2 cancer cells, with $\mathrm{IC}_{50}$ values of 8.0 and $5.2 \mu \mathrm{M}$, respectively [54]. From the coral Cladiella krempfi, four new eunicellin-based diterpenoids, krempfielins A-D, along with two known compounds, were isolated. Although two compounds, litophynol B and $\left(1 R^{*}, 2 R^{*}\right.$, $3 R^{*}, 6 S^{*}, 7 S^{*}, 9 R^{*}, 10 R^{*}, 14 R^{*}$ )-3-butanoyloxycladiell-11(17)-en-6,7-diol (87) (Figure 11), exhibited cytotoxicity against a limited panel of cancer cell lines (e.g., A549, BT483, MCF-7, SAS, H1299), only compound 87 showed potent cytotoxicity toward BT483 cell lines, with IC $_{50}$ values of $8.5 \pm 1.0 \mu \mathrm{g} / \mathrm{mL}$ $(21.6 \pm 2.5 \mu \mathrm{M})$. It is worthwhile to mention that two of these compounds were found to be noncytotoxic toward the normal cell line BEAS2B [92]. From the coral Sarcophyton auritum, Hegazy et al. [93] afforded one new cembrane diterpene and three known compounds. However, only compound $7 \beta$-acetoxy- $8 \alpha$-hydroxydeepoxysarcophine (88) (Figure 11) was found to display high cytotoxicity against HepG2, HTC-116, and HeLa cell lines, with $\mathrm{IC}_{50}$ values from $2.3 \pm 1.5$ to $6.7 \pm 0.8 \mu \mathrm{g} / \mathrm{mL}$ $(6.9 \pm 4.5$ to $20.1 \pm 2.4 \mu \mathrm{M})$. Chemical investigation of the coral Sinularia sp. yielded the isolation of two new polyhydroxysteroids, $12 \beta, 16 \beta, 20$-trihydroxycholesta-1,4-dien-3-one 16-acetate (89) (Figure 11) and 24 -methyl-12 $\beta, 16 \beta, 20$-trihydroxycholesta-1,4-dien-3-one. Two of these compounds showed cytotoxic effects against the MCF-7, Bel-7402, and HeLa cell lines. However, only compound 89 exhibited potent cytotoxicity toward MCF-7 cells, with an $\mathrm{IC}_{50}$ value of $3.82 \mu \mathrm{g} / \mathrm{mL}(8.1 \mu \mathrm{M})$ [94]. From the coral Lobophytum crassum, three new cembranoids, culobophylins A-C, along with two known compounds, were isolated. Interestingly, compound culobophylin A (90) (Figure 11) exhibited significant cytotoxic activity against MDA-MB-231, DLD-1, and HCT-116 cancer cell lines, with $\mathrm{IC}_{50}$ values of 3.0, 16.8, 4.6, and $16.3 \mu \mathrm{g} / \mathrm{mL}(9.4,52.8,14.5$, and $51.3 \mu \mathrm{M})$, respectively. Compound culobophylin B (91) (Figure 11) also exhibited cytotoxicity against HL60, DLD-1, and HCT-116 cell lines, with $\mathrm{IC}_{50}$ values of 6.8, 16.2, and $16.7 \mu \mathrm{g} / \mathrm{mL}(21.3,50.6$, and $52.2 \mu \mathrm{M})$, respectively. The cytotoxic activity of 90 against DLD- 1 (colon) cells was comparable to that of the positive control doxorubicin C $\left(\mathrm{IC}_{50}=5.7 \mu \mathrm{g} / \mathrm{mL}\right.$ or $\left.10.5 \mu \mathrm{M}\right)$ [95]. 
Chemical investigation of the coral Sinularia capillosa led to the isolation of capilloquinol (92) (Figure 11), which possessed an unprecedented farnesyl quinoid skeleton. Compound 92 displayed cytotoxicity against the P-388 cell line, with an median effective dose $\left(\mathrm{ED}_{50}\right)$ value of $3.8 \mu \mathrm{g} / \mathrm{mL}(10.8 \mu \mathrm{M})$ [96].
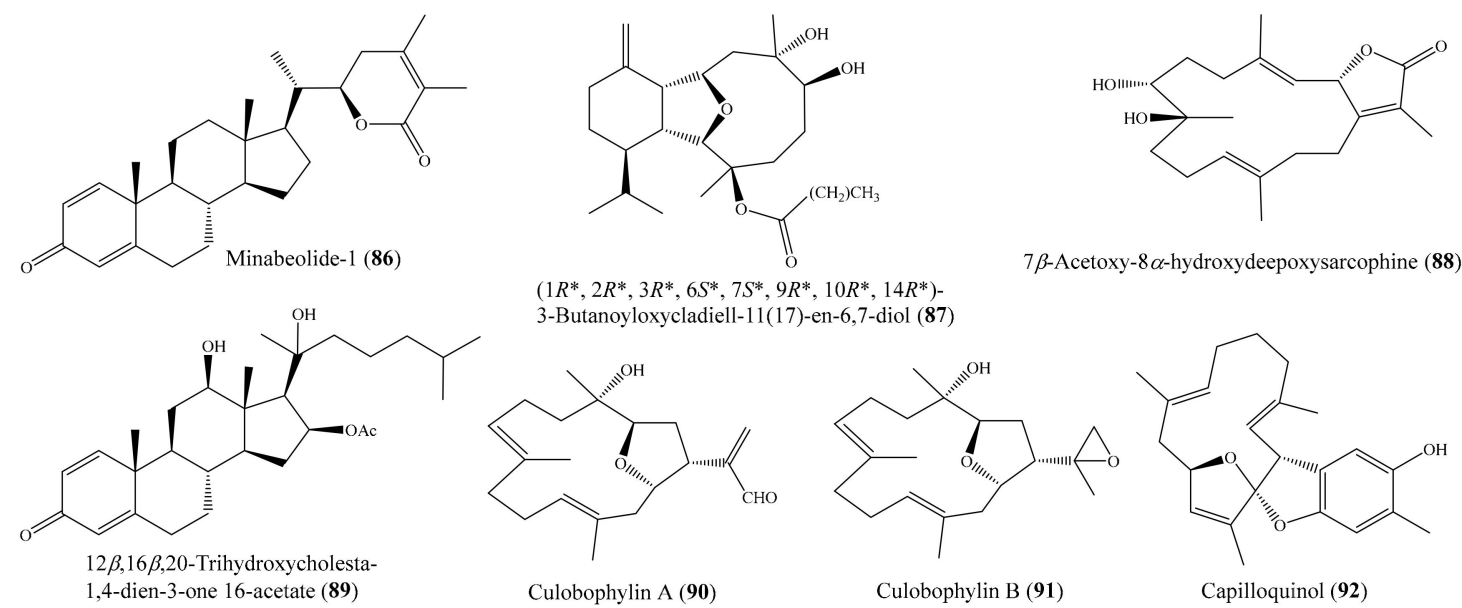

$\left(1 R^{*}, 2 R^{*}, 3 R^{*}, 6 S^{*}, 7 S^{*}, 9 R^{*}, 10 R^{*}, 14 R^{*}\right)$

$7 \beta$-Acetoxy- $8 \alpha$-hydroxydeepoxysarcophine (88) 3-Butanoyloxycladiell-11(17)-en-6,7-diol (87)
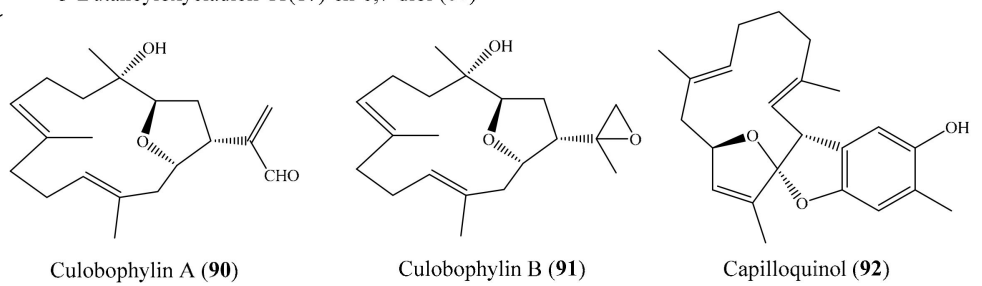

Figure 11. Chemical structures of $86-92$.

In another study, four new cembranoids and six known metabolites were isolated from the coral Lobophytum laevigatum (see Section 2.1). Compounds (+)-sarcophine, emblide, ximaolide F (6), methyl tortuoate B (7) (Figure 1), and nyalolide exhibited cytotoxic activity against selected human cancer cell lines (HL-60, A549, HCT-116, and MCF-7), with $\mathrm{IC}_{50}$ values ranging from 9.0 to $38.8 \mu \mathrm{M}$ [51]. Notably, the cytotoxic activity of $\mathbf{6}$ against the cell line HL-60 was comparable to that of the positive control mitoxantrone ( $\left.\mathrm{IC}_{50}=7.9 \pm 0.3 \mu \mathrm{M}\right)$. Lin et al. [56] isolated seven new cembranoids, sarcocrassocolides F-L, from the soft coral Sarcophyton crassocaule. All of these compounds exhibited significant cytotoxic activity against at least one cancer cell line (Daoy, HEp-2, MCF-7, and WiDr). Notably, compound sarcocrassocolide I (20) (Figure 3) displayed significant cytotoxicity against all of the above cell lines, with $\mathrm{ED}_{50}$ values of $5.1 \pm 1.2,5.8 \pm 0.5,8.4 \pm 1.5$, and $6.4 \pm 2.0 \mu \mathrm{M}$, respectively, suggesting that the acetoxy group of C-13 is important for the cytotoxicity of compound sarcocrassocolides $\mathrm{F}-\mathrm{L}$. It was also found that the hydroxyl group at C-8 could enhance the cytotoxicity of cembranoid sarcocrassocolides $\mathrm{F}-\mathrm{L}$ in comparison to C-8 hydroperoxy-bearing analogues [56]. In another chemical investigation, Lin et al. [97] obtained three new xenicane diterpenoids, asterolaurins $\mathrm{K}-\mathrm{M}$, from the coral Asterospicularia laurae. However, only compound asterolaurin L (93) (Figure 12) exhibited cytotoxic activity against HEp-2, Daoy, MCF-7, and WiDr tumor cells, with $\mathrm{IC}_{50}$ values of 4.12, $6.23,40.9$, and $6.08 \mu \mathrm{g} / \mathrm{mL}(11.8,17.8,116.9$, and $17.4 \mu \mathrm{M})$, respectively. From Sinularia granosa, a new 9,11-secosteroid, $8 \alpha \mathrm{H}-3 \beta, 11$-dihydroxy-5 $\alpha, 6 \alpha$-expoxy-24-methylene-9,11-secocholestan-9-one (94), along with one known steroid, $3 \beta, 11$-dihydroxy- $5 \beta, 6 \beta$-expoxy-24-methylene-9,11-secocholestan-9-one (95) (Figure 12), were isolated. Interestingly, compound 94 exhibited strong cytotoxicity against HeLa, HEp 2, Daoy, and MCF-7 cancer cell lines, with $\mathrm{ED}_{50}$ values of $8.21 \pm 1.61,6.21 \pm 1.38,5.53 \pm 1.58$, and $4.99 \pm 0.70 \mu \mathrm{g} / \mathrm{mL}(18.4 \pm 3.61,13.9 \pm 3.09,12.4 \pm 3.54$, and $11.2 \pm 1.57 \mu \mathrm{M})$, respectively, whereas compound 95 was found to be cytotoxic against Daoy and MCF-7 cancer cell lines, with ED 50 values of $7.07 \pm 0.71$ and $9.98 \pm 0.32 \mu \mathrm{g} / \mathrm{mL}(15.9 \pm 1.59$ and $22.4 \pm 0.72 \mu \mathrm{M})$, respectively [98]. From the coral Sinularia scabra, two new cadinane-type sesquiterpenoids, scabralins A and B, were obtained. However, only compound scabralin A (96) (Figure 12) exhibited cytotoxicity against MCF-7, WiDr, Daoy, and HEp 2 cancer cell lines, with $\mathrm{ED}_{50}$ values ranging from 7.6 to $13.8 \mu \mathrm{g} / \mathrm{mL}$ (or 32.2 to $58.5 \mu \mathrm{M})$ [99]. Two new hydroperoxyl cembranolides, a cembrene derivative (8-epi-sarcophinone), and two known cembranolides were isolated from the coral Sarcophyton glaucum. Among them, compounds 12(S)-hydroperoxylsarcoph-10-ene (97), 8-epi-sarcophinone (98), and ent-sarcophine (99) (Figure 12) were found to be potent inhibitors of cytochrome P450 1A activity, with $\mathrm{IC}_{50}$ values of $2.7,3.7$, and 
$3.4 \mathrm{nM}$, respectively. Furthermore, compounds 97 and 98 were promising inducers of glutathione $S$-transferase (GST) and quinone reductase (QR) activity in in vitro assays [100].
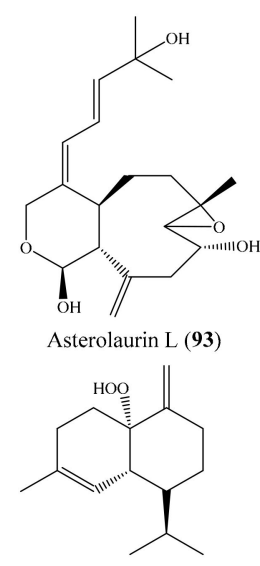

Scabralin A (96)

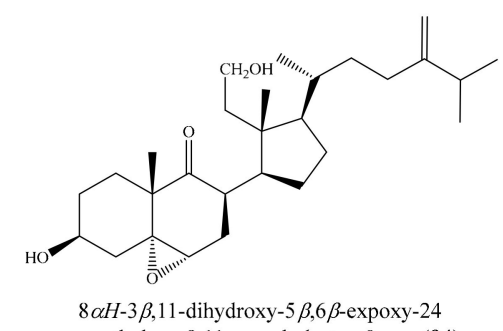

-methylene-9,11-secocholestan-9-one (94)

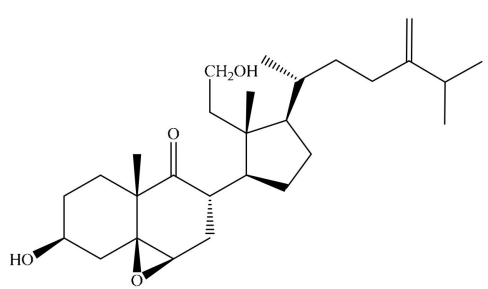

$3 \beta, 11$-dihydroxy- $5 \beta, 6 \beta$-expoxy- 24 -methylene-9,11-secocholestan-9-one (95)

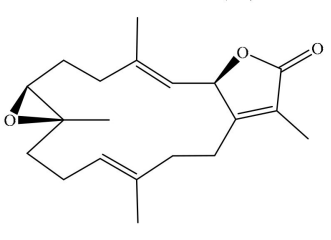

ent-Sarcophine (99)

Figure 12. Chemical structures of 93-99.

From the coral Cespitularia sp., five new diterpenoids, together with the known diterpenoid alcyonolide (100) (Figure 13), were also isolated. Interestingly, 100 exhibited strong cytotoxicity against HCT-116 cells, with an $\mathrm{IC}_{50}$ value of $5.85 \mu \mathrm{M}$, while new diterpenoids were much less active, with $\mathrm{IC}_{50}$ values ranging from 28.2 to $91.4 \mu \mathrm{M}$. It is likely that the lactone moiety (C-6-C-5-C-4a-C-4-C-12) and/or the acetal at C-1 are necessary for cytotoxicity [101]. In another study, three new polyoxygenated sterols, together with three known sterols, were isolated from the coral Sinularia sp. Among them, compound 24-methylenecholestane-3 $\beta, 5 \alpha, 6 \beta$-triol-6-monoacetate (101) (Figure 13) exhibited cytotoxicity against the $\mathrm{K} 562$ cell line, with an $\mathrm{IC}_{50}$ value of $3.18 \mu \mathrm{M}$, but it also displayed strong lethality toward the brine shrimp Artemia salina, with an $\mathrm{LC}_{50}$ value of $0.96 \mu \mathrm{M}$ [102]. Chemical investigation of the coral Lobophytum michaelae resulted in the isolation of six new cembranolides, michaolides L-Q (102-107) (Figure 1). Interestingly, all compounds, except for 105, exhibited remarkable cytotoxicity against P-388, HT-29, A-549, and HEL cell lines, with IC $_{50}$ values ranging from 0.4 to $4.9 \mu \mathrm{M}$. It was suggested that the $\alpha$-exo-methylene- $\gamma$-lactone moiety was important for cytotoxicity after a comparison of the

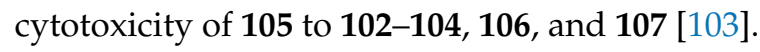
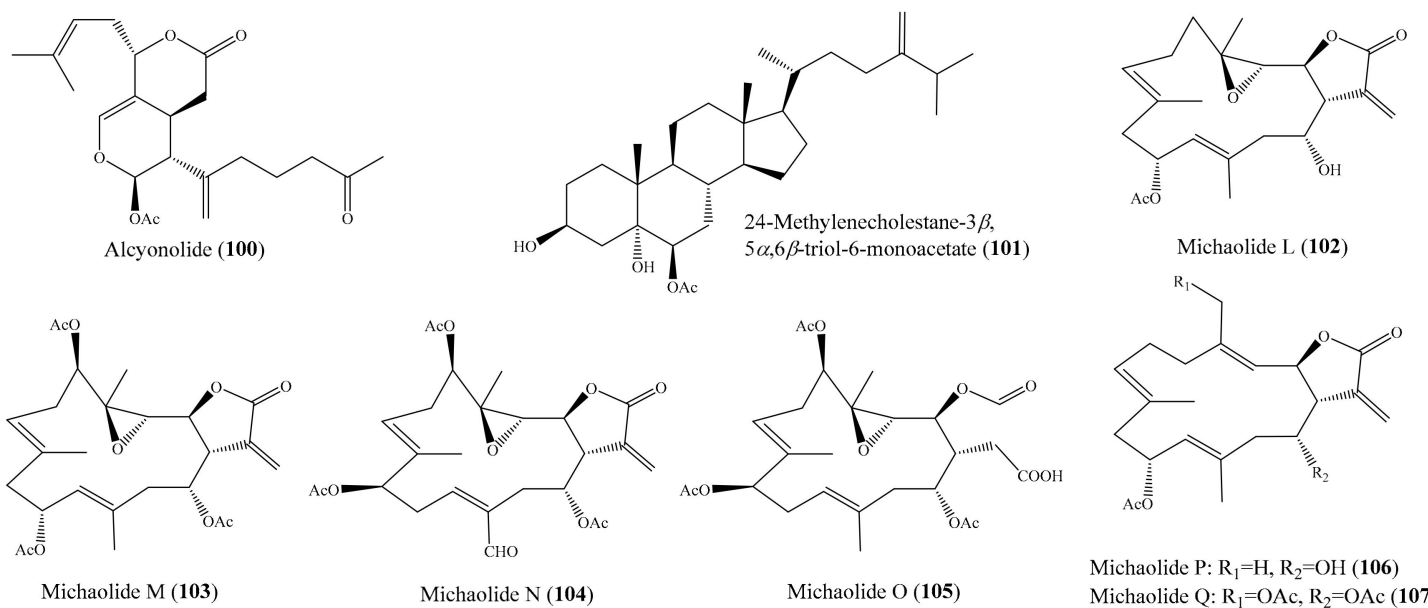

Michaolide $\mathrm{P}: \mathrm{R}_{1}=\mathrm{H}, \mathrm{R}_{2}=\mathrm{OH}(\mathbf{1 0 6})$ Michaolide Q: $\mathrm{R}_{1}=\mathrm{OAc}, \mathrm{R}_{2}=\mathrm{OAc}(107)$

Figure 13. Chemical structures of 100-107.

From the coral Sarcophyton ehrenbergi, three new cembranoids ((+)-12-ethoxycarbonyl-11Zsarcophine (108) and ehrenbergols A and B (109 and 110)) (Figure 14) were isolated. All of these new 
compounds displayed strong cytotoxicity against the P-388 cell line, with $\mathrm{ED}_{50}$ values of 5.8, 7.4, and $4.7 \mu \mathrm{g} / \mathrm{mL}(15.5,21.3,12.4 \mu \mathrm{M})$, respectively, whereas $\mathbf{1 0 8}$ and $\mathbf{1 1 0}$ showed moderate activity toward the A549 cell line, with $\mathrm{ED}_{50}$ values of 20.8 and $10.2 \mu \mathrm{g} / \mathrm{mL}$ (55.6 and $\left.27.0 \mu \mathrm{M}\right)$, respectively [104]. In another study, three new 19-oxygenated steroids, nebrosteroids N-P (111-113) (Figure 14), were also isolated from the coral Nephthea chabrolii. Interestingly, three new steroids exhibited potent cytotoxicity against the P-388 cell line, with $\mathrm{ED}_{50}$ values of $0.9,1.2$, and $1.7 \mu \mathrm{g} / \mathrm{mL}$, respectively $(1.96,2.46$, and $3.68 \mu \mathrm{M})$. The positive control mithramycin showed cytotoxicity against the A549, HT-29, and P-388 cancer cell lines, with $\mathrm{IC}_{50}$ values of $0.18,0.21$, and $0.15 \mu \mathrm{g} / \mathrm{mL}(0.17,0.19$, and $0.14 \mu \mathrm{M})$, respectively, but no cytotoxicity against HeLa cells [105]. Chemical investigation of the coral Lobophytum pauciflorum afforded a new 10-membered-ring diterpene, cyclolobatriene (114), along with three other known diterpenes: lobatriene (115), eunicol (116), and fuscol (117) (Figure 14). All four compounds showed potent cytotoxic effects against human epidermoid carcinoma A431 cells, with $\mathrm{IC}_{50}$ values of $0.64,0.41$, 0.35 , and $0.52 \mu \mathrm{M}$, respectively [106]. From the coral Sarcophyton crassocaule, three new cembranoids, sarcocrassocolides $\mathrm{M}-\mathrm{O}$ (25-27), were isolated (see Section 2.1). All of the new cembranoids were found to exhibit cytotoxicity toward the Daoy, HEp-2, MCF-7, and WiDr cancer cell lines. Notably, all three compounds displayed strong cytotoxicity against the Daoy cell line, with $\mathrm{ED}_{50}$ values of $6.6 \pm 0.8$, $5.2 \pm 0.6$, and $5.0 \pm 0.7 \mu \mathrm{M}$, respectively, whereas compound 27 showed remarkable cytotoxicity against the MCF-7 cell line, with an $\mathrm{ED}_{50}$ value of $6.4 \pm 0.5 \mu \mathrm{M}[58]$.

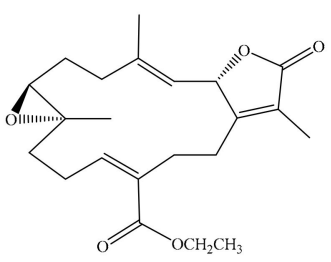

(+)-12-Ethoxycarbonyl-11Z-sarcophine (108)

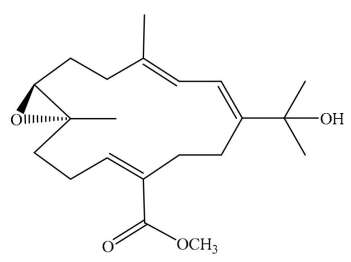

Ehrenbergol A (109)

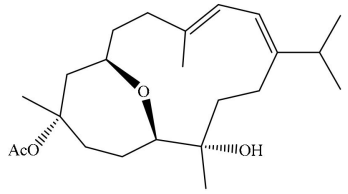

Ehrenbergol B (110)

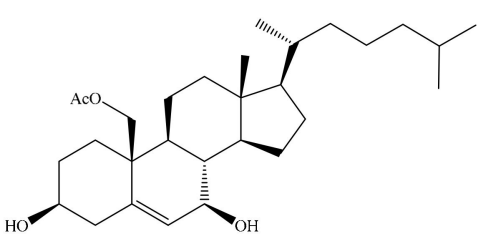

Nebrosteroid N (111)
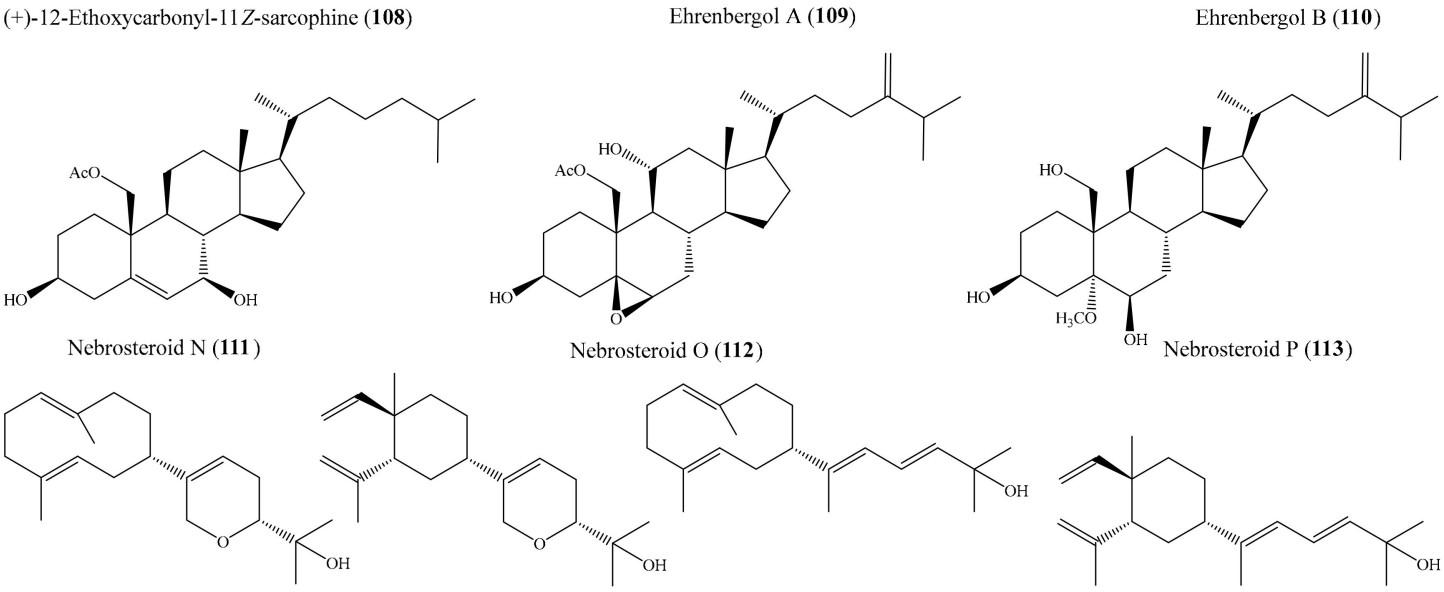

Cyclolobatriene (114)

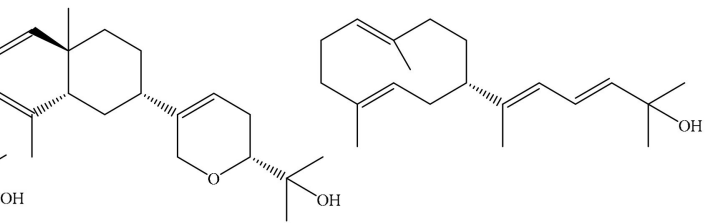

Lobatriene (115)

Eunicol (116)

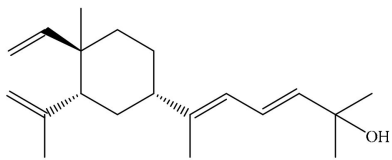

Fuscol (117)

Figure 14. Chemical structures of 108-117.

Chemical investigation of the coral Sinularia sp. led to the isolation of two norcembranoidal diterpenes, 5-episinuleptolide acetate (118) (Figure 15) and scabrolide D. However, only compound 118 was found to exhibit cytotoxicity toward K562, MOLT-4, HTC-11, DLD-1, T-47D, and MDA-MB-231 tumor cells, with $\mathrm{IC}_{50}$ values ranging from 0.59 to $4.09 \mu \mathrm{g} / \mathrm{mL}$ (1.51 to $10.49 \mu \mathrm{M}$ ). The positive control doxorubicin showed cytotoxicity against the K562, MOLT-4, HTC-11, DLD-1, T-47D, and MDA-MB-231 cancer cell lines, with $\mathrm{IC}_{50}$ values of $0.15,0.01,1.11,0.22,0.40$, and $1.30 \mu \mathrm{g} / \mathrm{mL}$, respectively $(0.28$, $0.02,2.04,0.40,0.74,2.39 \mu \mathrm{M})$ [107]. In another chemical investigation, one new dolabellane (119) and two known diterpenoids (stolonidiol (120) and clavinflol B (121)) (Figure 15) were isolated from the coral Anthelia sp. Among them, compound 119 exhibited cytotoxicity against NBT-T2 cells at $10 \mu \mathrm{g} / \mathrm{mL}(31.25 \mu \mathrm{M})$, while known compounds $\mathbf{1 2 0}$ and $\mathbf{1 2 1}$ showed stronger cytotoxicity at 1.0 and 
$0.5 \mu \mathrm{g} / \mathrm{mL}$ (2.98 and $1.34 \mu \mathrm{M})$, respectively [108]. Chao et al. [109] isolated three new steroidal carboxylic acids, paraminabic acids A-C, from the coral Paraminabea acronocephala. However, only compound paraminabic acid C (122) (Figure 15) showed potent cytotoxicity toward the Hep3B, MDA-MB-231, MCF-7, and A-549 cancer cell lines, with $\mathrm{IC}_{50}$ values ranging from 2.05 to $2.83 \mu \mathrm{g} / \mathrm{mL}$ (4.81 to $6.64 \mu \mathrm{M}$ ). The positive control doxorubicin showed cytotoxicity against the Hep G2, Hep 3B, MDA-MB-231, MCF-7, and A549 cancer cell lines, with $\mathrm{IC}_{50}$ values of $0.31,0.40,1.32,0.68$, and $1.33 \mu \mathrm{g} / \mathrm{mL}(0.57$, $0.74,2.43,1.25$, and $2.45 \mu \mathrm{M})$, respectively. From the coral Cladiella krempfi, five new eunicellin-based diterpenoids and seven known compounds were isolated. Among them, 6-acetoxy litophynin E (123) and litophynin F (124) (Figure 15) exhibited effective cytotoxicity against the A549, BT483, H1299, HepG2, SAS, and BEAS2B cell lines, with $\mathrm{IC}_{50}$ values ranging from $4.8 \pm 0.7$ to $13.6 \pm 0.5 \mu \mathrm{g} / \mathrm{mL}$ $(11.8 \pm 6.6$ to $13.9 \pm 1.3 \mu \mathrm{M})$, whereas krempfielin I and 6-methyl ether of litophynol B were less active [62]. In another study, two new cembrane-based diterpenoids, 11-acetylsinuflexolide and 11-acetyldihydrosinuflexolide, along with three known cembranoids (sinuflexolide, sinularin, and dihydrosinularin), were isolated from the coral Sinularia flexibilis. Interestingly, compound sinuflexolide (125) (Figure 15) exhibited cytotoxicity against the HeLa, HEp-2, MCF-7, and MDA-MB-231 cancer cell lines, with $\mathrm{IC}_{50}$ values of $8.6,8.2,16.0$, and $11.3 \mu \mathrm{g} / \mathrm{mL}(24.4,23.3,45.5$, and $32.1 \mu \mathrm{M})$, respectively, whereas the compounds 11-acetylsinuflexolide and sinularin were found to exhibit weak cytotoxicity toward some of the cell lines. According to a structure-activity relationship analysis of the five described cembrane-based diterpenoids, it seems that the $\alpha$-exomethylenic- $\delta$-lactone ring group in the compounds 11-acetylsinuflexolide, sinuflexolide, and sinularin is critical to the cytotoxic activity of the cembrane-based diterpenoids [110].

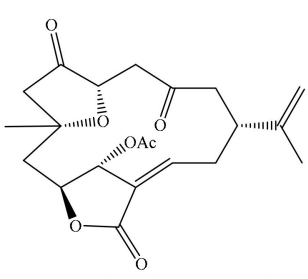

5-Episinuleptolide acetate (118)

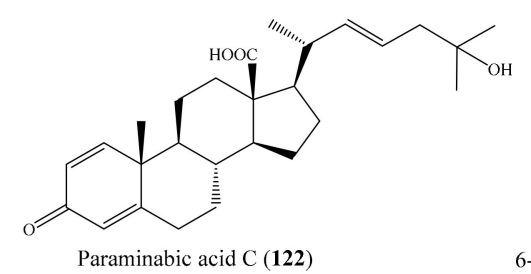

Paraminabic acid C (122)

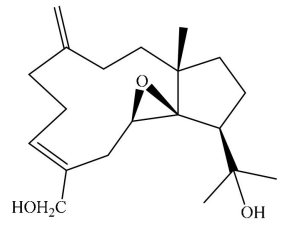

Dolabellane (119)

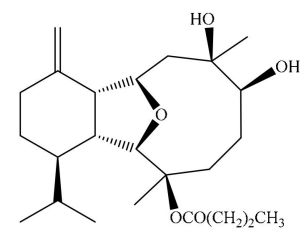

6-Acetoxy litophynin E (123)

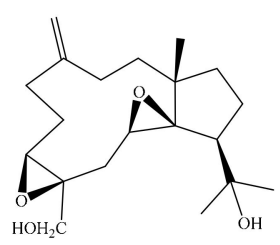

Stolonidiol (120)

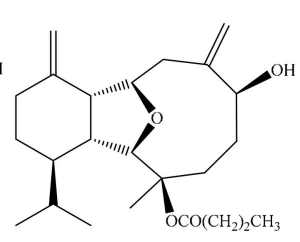

Litophynin F (124)

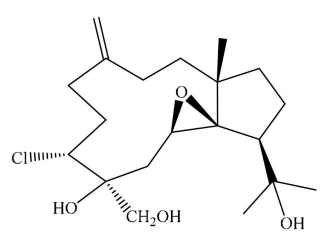

Clavinflol B (121)

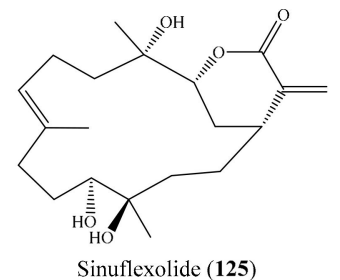

Figure 15. Chemical structures of 118-125.

From the coral Sinularia brassica, seven novel withanolides, sinubrasolides A-G, were isolated. Among them, compound sinubrasolide B (126) (Figure 16) exhibited cytotoxicity toward the P388, MOLT 4, and HT-29 cancer cell lines, with $\mathrm{ED}_{50}$ values of $9.1 \pm 1.4,4.8 \pm 0.9$, and $4.8 \pm 0.7 \mu \mathrm{M}$, respectively, while sinubrasolide $\mathrm{E}$ (127) (Figure 16) was found to show cytotoxicity toward MOLT-4 and HT-29, with $\mathrm{ED}_{50}$ values of $9.9 \pm 1.8$ and $7.5 \pm 1.5 \mu \mathrm{M}$. In addition, sinubrasolide A (128) (Figure 16) showed cytotoxicity toward the $\mathrm{K} 562$ cell line, with an $\mathrm{ED}_{50}$ value of $8.7 \pm 1.4 \mu \mathrm{M}$. The cytotoxicity of 126-128 was comparable to that of the positive control 5-fluorouracil toward P388, MOLT 4, K-562, and HT-29 cells, with $\mathrm{ED}_{50}$ values of $6.2 \pm 0.8,7.7 \pm 0.8,21 \pm 2.0$, and $7.7 \pm 0.8 \mu \mathrm{M}$, respectively [111]. From the coral Sinularia polydactyla, three known terpenoides were isolated. Among them, the compound durumolide C (129) (Figure 16) showed strong cytotoxicity against the HepG2 cancer cell line, with an $\mathrm{IC}_{50}$ value of $1.0 \mu \mathrm{g} / \mathrm{mL}(3.0 \mu \mathrm{M})$, whereas the compound 24 -methylcholestane-3 $\beta, 5 \alpha, 6 \beta, 25$-tetrol 25-monoacetate (130) (Figure 16) showed strong cytotoxicity against the Hep2 and HCT-116 cancer cell lines, with $\mathrm{IC}_{50}$ values of 6.1 and $8.2 \mu \mathrm{g} / \mathrm{mL}(12.8$ and $17.2 \mu \mathrm{M})$, respectively. The positive control 
doxorubicin exhibited cytotoxicity toward HepG2 cancer cells, with an $\mathrm{IC}_{50}$ value of $1.2 \mu \mathrm{g} / \mathrm{mL}$ $(2.2 \mu \mathrm{M})$, whereas the positive control vinblastine exhibited cytotoxicity toward the HCT and Hep2 cancer cell lines, with $\mathrm{IC}_{50}$ values of 4.6 and $2.6 \mu \mathrm{g} / \mathrm{mL}(5.67$ and $3.2 \mu \mathrm{M})$, respectively [112]. In another study, five new steroids ( $(12 \beta, 22 R)$-12-acetoxy-22-hydroxy-cholesta-1,4-dien-3-one (131), (12 $\beta$, 22R)-12-hydroxy-22-acetoxy-cholesta-1, 4-dien-3-one (132), (12 $\beta, 22 R)-12,22$-diacetoxy-cholesta-1, 4-dien-3-one, (22R)-18, 22-diacetoxy-cholesta-1, 4-dien-3-one (133) (Figure 16), and (20R, 22R)-20hydroxy-22-acetoxy-cholesta-1,4-dien-3-one), along with one known steroid (astrogorgol N), were isolated from the coral Nephthea sp. Although all of these compounds exhibited cytotoxic activity against the HeLa cell line, compounds 131-133 showed stronger activities, with $\mathrm{IC}_{50}$ values of $7.51 \pm 0.22$, $7.50 \pm 0.31$, and $8.29 \pm 0.42 \mu \mathrm{g} / \mathrm{mL}(17.00 \pm 0.50,16.97 \pm 0.70$, and $18.50 \pm 0.94 \mu \mathrm{M})$, respectively. After a comparison of the $\mathrm{IC}_{50}$ values of the compounds, it was suggested that the presence of a free hydroxyl group either at C-12 or C-22 was important for the enhancement of cytotoxic activity against HeLa cells. Moreover, it was observed that the introduction of a hydroxyl group at C-20 could decrease the inhibitory potency against HeLa cells, whereas the presence of an acetoxy group at C-18 seemed to enhance the cytotoxic activity [113].

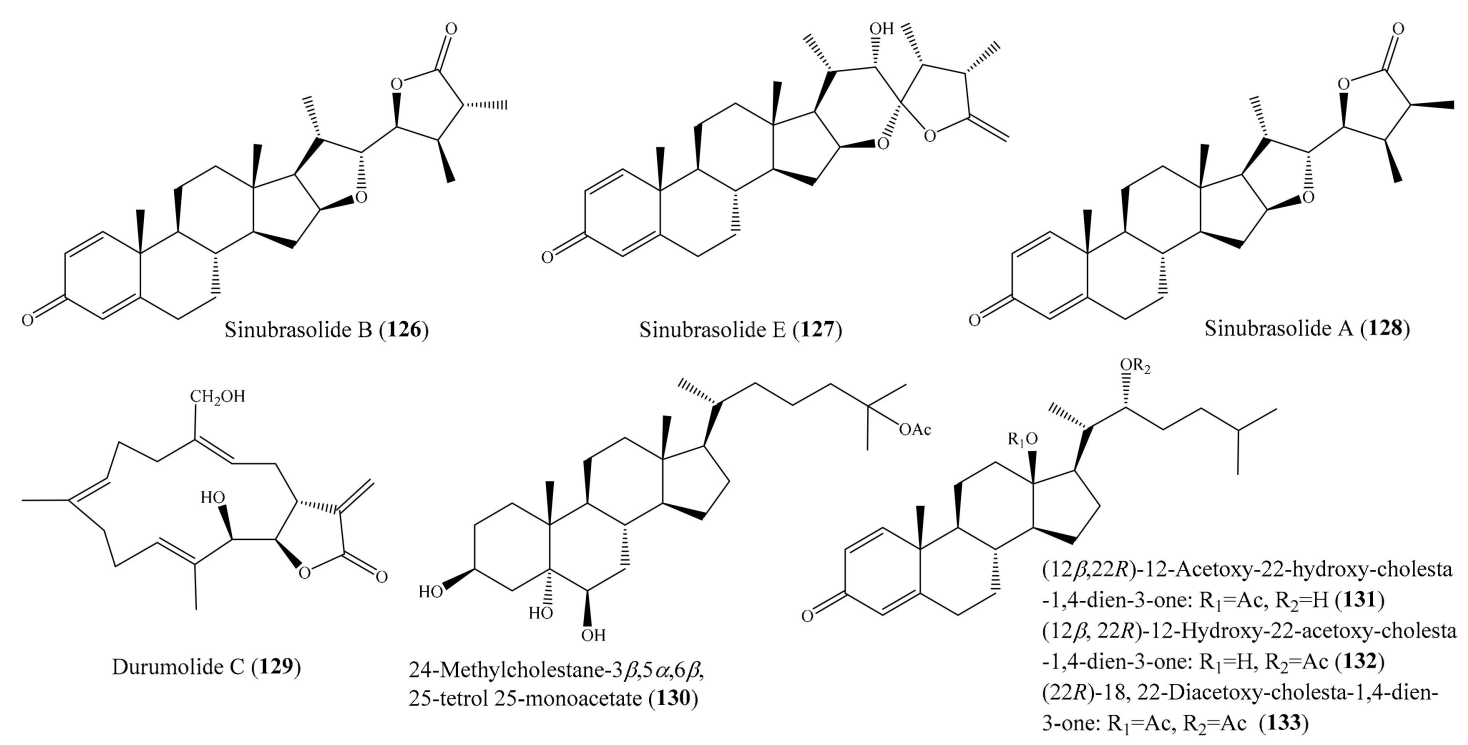

Figure 16. Chemical structures of 126-133.

Chemical investigation of the coral Sarcophyton sp. led to the isolation of three new polyhydroxylated steroids, together with seven known steroids. Among them, the compounds (24R)gorgost-25-en-3 $\beta, 5 \alpha, 6 \beta, 11 \alpha$-tetraol (134), $11 \alpha$-acetoxy-cholest-24-en-3 $\beta, 5 \alpha, 6 \beta$-triol (135), (22E,24S)$11 \alpha$-acetoxy-ergost-22, 25 -dien-3 $\beta, 5 \alpha, 6 \beta$-triol (136), and (24R)-11 $\alpha$-acetoxy-gorgost-3 $\beta, 5 \alpha, 6 \beta$-triol (137) (Figure 17) exhibited good cytotoxicity against the $\mathrm{K} 562$ cell line, with $\mathrm{IC}_{50}$ values of less than $10.0 \mu \mathrm{M}$, whereas the compound $(23 R, 24 R, 17 Z)-11 \alpha$-acetoxy-16 $\beta$-methoxy-23,24dimethylcholest-17(20)-en-3 $\beta, 5 \alpha, 6 \beta$-triol (138) (Figure 17) displayed effective cytotoxicity toward the HL-60 tumor cell line, with an $\mathrm{IC}_{50}$ value of $9.3 \mu \mathrm{M}$. A comparative analysis of the structure-activity relationship of the isolated steroids suggested that the 11-OAc group is a very important pharmacophore. Furthermore, it was observed that the $\mathrm{OH}$ substitution at $\mathrm{C}-11$ could improve the selectivity but decrease activity [114]. Zhao et al. [115] isolated three new $\alpha$-methylene- $\gamma$-lactone-containing cembranoids

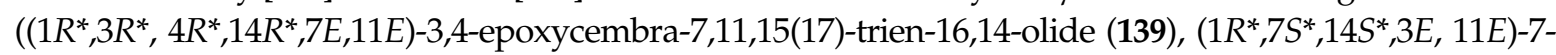
hydroperoxycembra-3,8(19),11,15(17)-tetraen-16,14-olide (140), and $\left(1 R^{*}, 7 S^{*}, 14 S^{*}, 3 E, 11 E\right)$-18-acetoxy7-hydroperoxycembra-3,8(19),11,15(17)-tetraen-16,14-olide (141)) (Figure 17) from the coral Lobophytum sp. Interestingly, the three new compounds exhibited remarkable cytotoxicity against the selected tumor cell lines (SGC7901, A549, MCF7, HCT-116, and B16), with $\mathrm{IC}_{50}$ values ranging from 1.2 to $8.6 \mu \mathrm{g} / \mathrm{mL}(4.0$ to $27.2 \mu \mathrm{M})$. 

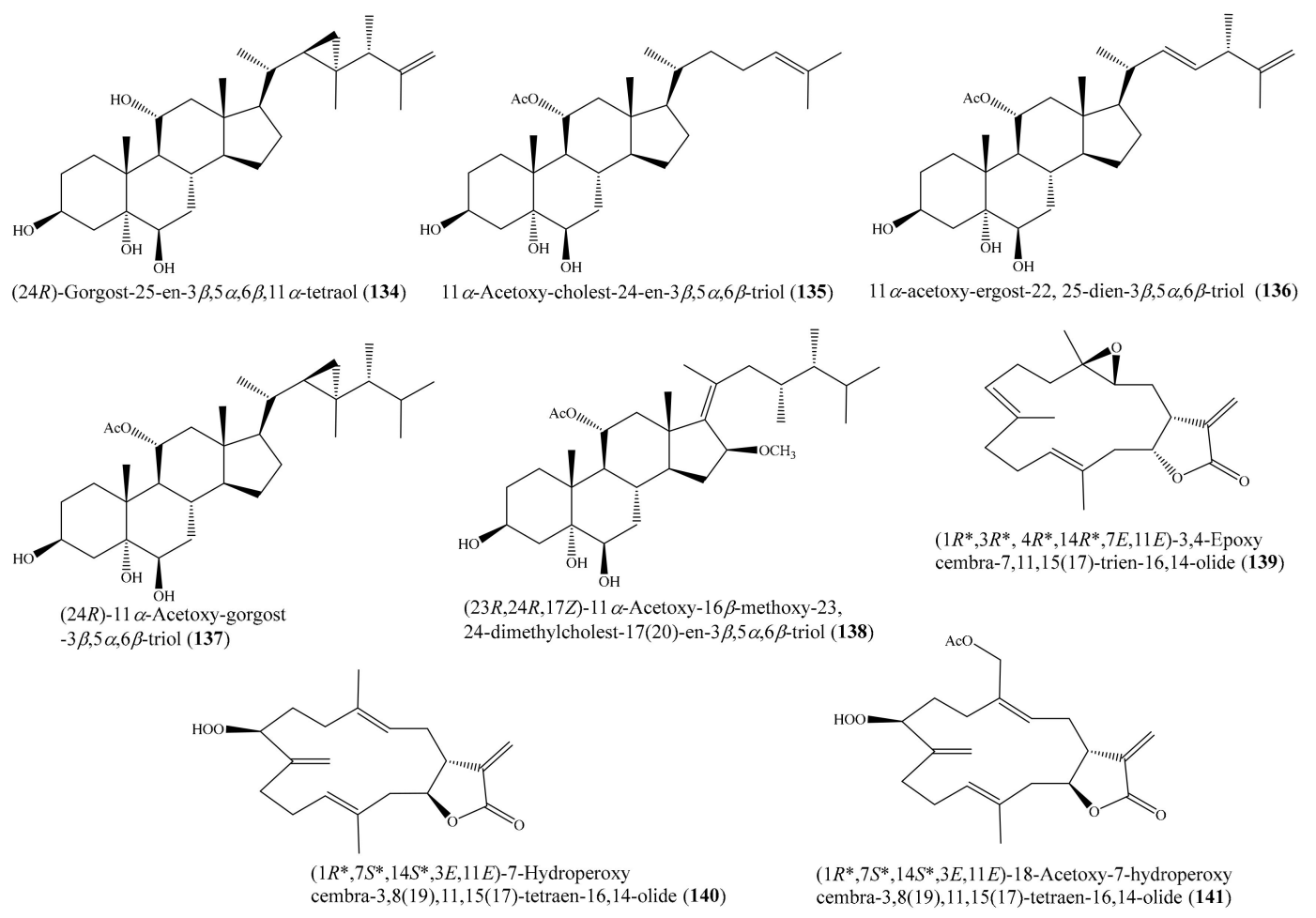

Figure 17. Chemical structures of 134-141.

Chemical investigation of the coral Klyxum molle afforded 11 new eunicellin-based diterpenoids (see Section 2.1). However, only compound klymollin M (38) (Figure 5) exhibited strong cytotoxicity toward the K562, MOLT-4, and T47D cancer cell lines, with $\mathrm{ED}_{50}$ values of $7.97 \pm 2.55,4.35 \pm 0.63$, and $8.58 \pm 1.72 \mu \mathrm{M}$, respectively, suggesting that eunicellin- based metabolites bearing a phenylacetate, as in 38, may have enhanced cytotoxicity. Compound 38 exhibited stronger activity than the positive control 5-fluorouracil, which exhibited cytotoxic activity toward the K562, Molt-4, and T47D cancer cell lines, with $\mathrm{ED}_{50}$ values of $16.22 \pm 1.77,15.07 \pm 1.61$, and $50.20 \pm 13.22 \mu \mathrm{M}$, respectively [66]. Ellithey et al. [116] reported the isolation of nine compounds from the coral Litophyton arboreum, of which the compounds $7 \beta$-acetoxy-24-methylcholesta-5-24 (28)-diene-3,19-diol (142) and 24-methylcholesta-5,24(28)-diene-3 $\beta, 7 \beta, 19$-triol (143) (Figure 18) were found to exhibit strong cytotoxicity against HeLa cells, with $\mathrm{IC}_{50}$ values of $4.3 \pm 0.75$ and $8 \pm 0.5 \mu \mathrm{M}$, respectively. The cytotoxicity of $\mathbf{1 4 2}$ and $\mathbf{1 4 3}$ toward Hela cells was comparable to that of the positive control actinomycin D, with $\mathrm{IC}_{50}$ values of $5.1 \pm 0.1 \mu \mathrm{M}$. In another study, Yen et al. [117] isolated a new sterol and two known sterols from the coral Sinularia gaweli. Notably, the compound 24-methylenecholestane-1 $\alpha, 3 \beta, 5 \alpha, 6 \beta, 11 \alpha$-pentol (144) (Figure 18) exhibited strong cytotoxicity toward the K562, MOLT-4, and HL-60 cell lines, with $\mathrm{IC}_{50}$ values of $9.71,6.91$, and $3.39 \mu \mathrm{g} / \mathrm{mL}$, respectively $(20.9,14.9$, and $7.3 \mu \mathrm{M})$. Three pregnane-type steroids, including a new metabolite along with two known analogues, were isolated from the coral Scleronephthya flexilis. Among them, only the compound 5 $\alpha$-pregna-1,20-dien-3-one (145) (Figure 18) exhibited potent activity against MOLT-4, HL-60, and K562 tumor cells, with $\mathrm{IC}_{50}$ values of $2.15,3.14$, and $8.32 \mu \mathrm{g} / \mathrm{mL}$, respectively $(7.21,10.54$, and $27.92 \mu \mathrm{M})$ [118]. From the coral Dendronephthya sp., three new ylangene-type sesquiterpenoids, dendronephthols A-C, were isolated. Interestingly, the compounds dendronephthol A (146) and dendronephthol C (147) (Figure 18) showed significant cytotoxic activity against the murine lymphoma L5187Y cancer cell line, with $\mathrm{ED}_{50}$ values of 8.4 and $6.8 \mu \mathrm{g} / \mathrm{mL}$ (33.3 and $25.6 \mu \mathrm{M}$ ), respectively [119]. In 2014, Chang et al. [120] isolated five new eunicellin-based diterpenoids, klymollins T-X, along with two known eunicellin-based diterpenoids, sclerophytin A and sclerophytin B, from the coral Klyxum molle. The compound klymollin W (148) (Figure 18) exhibited cytotoxicity toward the CCRF-CEM, MOLT-4, 
and T47D cancer cell lines, with $\mathrm{ED}_{50}$ values of 9.6, 8.5, and $19.9 \mu \mathrm{g} / \mathrm{mL}(22.7,20.1$, and $47.2 \mu \mathrm{M})$, respectively, whereas sclerophytin B (149) (Figure 18) showed cytotoxicity against the CCRF-CEM, $\mathrm{K} 562$, MOLT-4, and T47D cell lines, with $\mathrm{ED}_{50}$ values of 4.2, 15.0, 16.5, and $12.4 \mu \mathrm{g} / \mathrm{mL}(11.1,39.5,43.4$, and $32.6 \mu \mathrm{M})$, respectively.
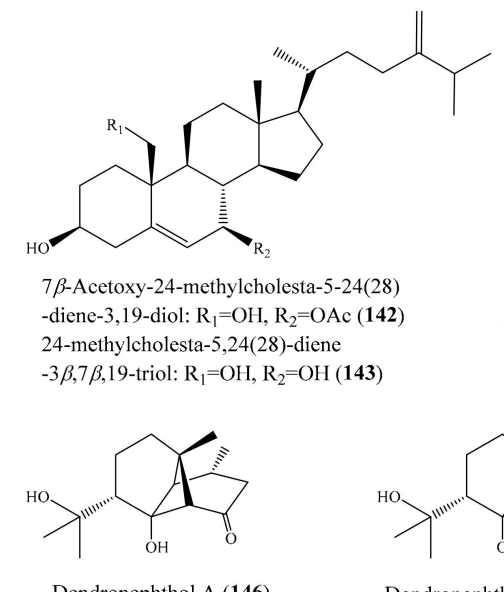

Dendronephthol A (146)

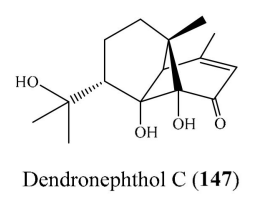

Figure 18. Chemical structures of 142-149.

Klymollin W (148)

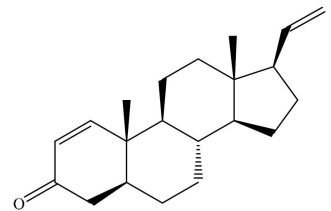

$5 \alpha$-Pregna-1,20-dien-3-one (145)

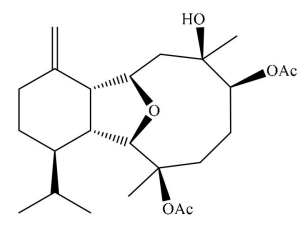

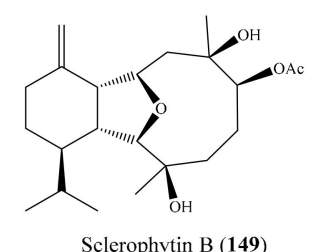

Sclerophytin B (149)

A subsequent investigation effort of the coral Sarcophyton trocheliophorum led to the isolation of two new rare pyrane-based cembranoids (sarcotrocheliol acetate and sarcotrocheliol), along with two known cembranoids (cembrene-C and sarcophine) and the aromadendrene sesquiterpenoid palustrol. Bioassays indicated that sarcophine (150) and palustrol (151) (Figure 19) recorded antitumor activities against lymphoma and Ehrlich cell lines, with an median lethal dose $\left(\mathrm{LD}_{50}\right)$ in the range of 2.5-3.79 $\mu \mathrm{M}$ [121]. A chemical study of the coral Sinularia sp. yielded one novel nine-membered macrocyclic polysulfur cembranoid lactone, sinulariaoid A, and three new multioxygenated cembranoids, sinulariaoids $B-D$, together with four known cembranoids. Of these, sinulariaoid A (152) (Figure 19) exhibited the most potent in vitro anticancer activity, and its cytotoxicity in HepG2/ADM was more potent than in the other three cell lines (HepG2, MCF-7, and MCF-7/ADM), with an $\mathrm{IC}_{50}$ value of $9.70 \pm 1.77 \mu \mathrm{M}$. Interestingly, the cytotoxic activity of 8 and 152 against the multidrug-resistant cell lines HepG2/ADM and MCF-7/ADM was comparable to that of the positive control doxorubicin. Furthermore, it was found that compound $\mathbf{1 5 2}$ induced apoptosis, and its selective toxicity toward HepG2/ADM cells was not related to P-glycoproteins [122]. In another chemical investigation, Roy et al. [123] reported the isolation of two new alcyonolide congeners, trisnorditerpenoid 1 and diterpenoid 2, from the coral Cespitularia sp. Interestingly, both compounds showed cytotoxicity against HCT-116 cells; however, trisnorditerpenoid 1 (153) (Figure 19) showed stronger activity, with an $\mathrm{IC}_{50}$ value of $6.04 \mu \mathrm{M}$. From another coral, Nephthea erecta, Cheng et al. [124] obtained two new kelsoane-type sesquiterpenes, kelsoenethiol and dikelsoenyl ether. Notably, only the compound kelsoenethiol (154) (Figure 19) showed cytotoxicity against P-388 and HT-29 cells, with $\mathrm{ED}_{50}$ values of 1.3 and $1.8 \mu \mathrm{g} / \mathrm{mL}(5.5$ and $7.6 \mu \mathrm{M})$, respectively. It was noted that the mercaptan group at C-12 exhibited cytotoxic activity against P-388 and HT-29 cells more potently than kelsoene did, suggesting that the presence of the C-12 mercaptan group is important for cytotoxicity against P-388 and HT-29 cells. In another effort, Al-Lihaibi et al. [125] isolated three new cembranoids (sarcophytolol, sarcophytolide B, and sarcophytolide C) along with three known metabolites (10(14)aromadendrene, deoxosarcophine, and sarcophine) from the coral Sarcophyton glaucum. Among them, compound 10(14)-aromadendrene (155) (Figure 19) showed potent cytotoxicity activity toward PC-3, with an IC 50 value of $9.3 \pm 0.164 \mu \mathrm{M}$, whereas the compounds sarcophytolol and sarcophytolide $C$ had similar moderate cytotoxic effects toward the HepG2 cell line, with an $\mathrm{IC}_{50}$ value of $20 \mu \mathrm{M}$. Furthermore, the compounds sarcophytolide B and C showed moderate activity against the MCF-7 cell line, with $\mathrm{IC}_{50}$ 
values of $25 \pm 0.0164$ and $29 \pm 0.030 \mu \mathrm{M}$, respectively. The antiproliferative activity of sarcophytolol, sarcophytolide $C$, and $\mathbf{1 5 5}$ could be attributed, at least partly, to their ability to induce cellular apoptosis. Interestingly, all of the metabolites showed no cytotoxicity against normal adult African green monkey kidney (VERO) cells even at $100 \mathrm{mM}$. From the coral Sarcophyton crassocaule, three new cembranoids (46-48) and four known compounds (49-52) (Figure 6) were isolated (see Section 2.1). Of these, compounds $\mathbf{4 8 - 5 0}$ and $\mathbf{5 2}$ were found to exhibit strong cytotoxicity toward all or part of the carcinoma cell lines DLD-1, CCRF-CEM, and HL-60, with $\mathrm{ED}_{50}$ values ranging from 3.8 to $11.1 \mu \mathrm{M}$ [72].

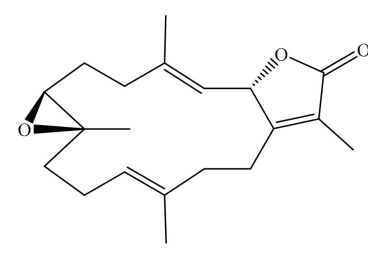

Sarcophine (150)

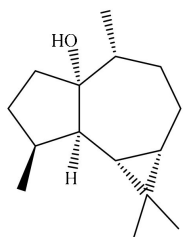

Palustrol (151)

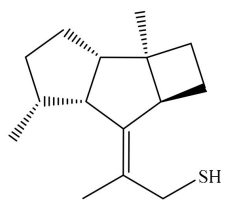

Kelsoenethiol (154)
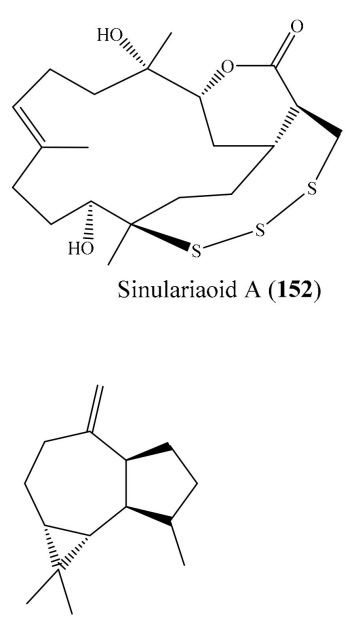

10(14)-Aromadendrene (155)

Figure 19. Chemical structures of 150-155.

From the coral Sinularia numerosa, four new cembrane-type diterpenes, numerosols A-D, along with a known steroid, gibberoketosterol (156) (Figure 20), were isolated. Interestingly, only 156 exhibited cytotoxicity against the P-388 cell line, with an $\mathrm{ED}_{50}$ of $6.9 \mu \mathrm{M}$ [126]. In another study, Lin et al. [127] isolated two novel diterpenoids, cespitulones $A$ and $B$, which possess an unprecedented bicyclo ring system with C-C bond connections between C-10 and C-20 and between C-20 and C-11, from the coral Cespitularia taeniata. However, only the compound cespitulone A (157) (Figure 20) exhibited significant cytotoxicity against the Daoy and WiDr cancer cell lines, with $\mathrm{IC}_{50}$ values of 8.7 and $6.7 \mu \mathrm{M}$, respectively. Chemical investigation of the coral Klyxum flaccidum afforded six new steroids, klyflaccisteroids A-E, and a new 9,11-secogorgosteroid, klyflaccisteroid F, along with two known steroids and a known eunicellin-based diterpenoid (see Section 2.1). The compound klyflaccisteroid A (158) (Figure 20) could selectively inhibit the growth of A549 cancer cells, with an $\mathrm{ED}_{50}$ value of $7.7 \mu \mathrm{g} / \mathrm{mL}(18.0 \mu \mathrm{M})$, whereas the compound klyflaccisteroid E (61) exhibited the strongest cytotoxicity toward the HT-29 cancer cell line, with an $\mathrm{ED}_{50}$ of $6.9 \mu \mathrm{g} / \mathrm{mL}(15.1 \mu \mathrm{M})$. In addition, the klyflaccisteroids $\mathrm{C}$ and $\mathrm{E}$ (58 and 61) (Figure 7) were found to be the most toxic toward A549 and P388 cells, with ED ${ }_{50}$ values of 6.1 and $3.7 \mu \mathrm{g} / \mathrm{mL}(13.4$ and $8.1 \mu \mathrm{M})$, respectively. Interestingly, compounds 58 and 158 showed stronger activity against the A549 cell line than the positive control 5-fluorouracil $\left(\mathrm{ED}_{50}=14.3 \mu \mathrm{g} / \mathrm{mL}\right.$ or $109.9 \mu \mathrm{M}$ ) did [75]. From the coral Sinularia erecta, four new isoprenoids, along with three known isoprenoids and a known nitrogen-containing compound, were isolated (see Section 2.1). The cytotoxic assay showed that the compound sinulerectadione (159) (Figure 20) exhibited cytotoxicity toward the K-562 and MOLT- 4 cancer cell lines, with $\mathrm{IC}_{50}$ values of $8.6 \pm 1.1$ and $9.7 \pm 2.9 \mu \mathrm{M}$, respectively, while sinulerectol C (160) (Figure 20) showed cytotoxicity toward the K-562 cell line, with an $\mathrm{IC}_{50}$ value of $9.2 \pm 3.3 \mu \mathrm{M}$. In addition, (Z)- $N$-[2-(4-hydroxyphenyl)ethyl]-3-methyldodec-2-enamide (57) was found to show cytotoxicity toward CCRF-CEM and MOLT-4, with $\mathrm{IC}_{50}$ values of $6.3 \pm 1.5$ and $9.7 \pm 3.6 \mu \mathrm{M}$, respectively. Notably, the cytotoxic activity of $\mathbf{1 5 9}$ and $\mathbf{1 6 0}$ against the K-562 cancer cell line was stronger than that of the positive control 5-fluorouracil $\left(\mathrm{IC}_{50}=33 \pm 9 \mu \mathrm{M}\right)$, and the cytotoxic activity of 157 against the CCRF-CEM (leukemia) cancer cell line was stronger than that of the positive control 
$\left(\mathrm{IC}_{50}=17 \pm 5 \mu \mathrm{M}\right)$ [74]. Furthermore, from the coral Sarcophyton glaucum, two new biscembranes, glaucumolides A and B $(62,63)$ (Figure 7), along with two known metabolites, were isolated (see Section 2.1), of which both new compounds, 62 and 63, exhibited cytotoxicity against the HL-60, CCRF-CEM, MOLT-4, and K562 cancer cell lines, with ED 50 values ranging from 3.8 to $19.2 \mu \mathrm{g} / \mathrm{mL}$ (5.5 to $27.8 \mu \mathrm{M}$ ). The cytotoxic activity of 62 and 63 against the HL-60 cancer cell line was stronger than that of the control 5-fluorouracil ( $\mathrm{IC}_{50}=10.7 \pm 0.5 \mu \mathrm{g} / \mathrm{mL}$ or $82.3 \pm 3.8 \mu \mathrm{M}$ ) [76]. In another study, four new polyhydroxylated steroids together with six known compounds were isolated from the coral Sinularia acuta. The compounds $(3 \beta, 5 \alpha, 6 \beta, 22 E)-3,5$-dihydroxy-24-oxocholest-22-en-6-yl acetate (161) and 24-methylidenecholestane-3 $\beta, 5 \alpha, 6 \beta$-triol 6-monoacetate (162) (Figure 20) showed potent cytotoxicity against HL-60 cell lines, with $\mathrm{IC}_{50}$ values of 7.3 and $9.9 \mu \mathrm{M}$, respectively, whereas the compounds 24-methylidenecholestane-3 $\beta, 5 \alpha, 6 \beta$-triol 6-monoacetate and (24S)-methylidenecholestane-3 $3,5 \alpha, 6 \beta$-triol 6-monoacetate showed moderate activity against K562 cell lines, with $\mathrm{IC}_{50}$ values of 10.9 and $11.7 \mu \mathrm{M}$, respectively. Furthermore, 161 and (24S)-methylidenecholestane-3 $\beta, 5 \alpha, 6 \beta$-triol 6-monoacetate showed weak activity against HeLa cell lines, with respective $\mathrm{IC}_{50}$ values of $44.8,27.1$, and $18.2 \mu \mathrm{M}$ [128]. The structure-activity comparison suggested that the $3 b, 5 a, 6 b$-triol pattern could be a critical pharmacophore for steroids and that the side chain also plays an important role. This structure-activity relationship assumption was consistent with a recent study on the polyhydroxylated steroids from another soft coral, Sarcophyton sp. [114]. In addition, from the coral Sarcophyton pauciplicatum, two new biscembranoids, sarcophytolides $\mathrm{M}$ and $\mathrm{N}$, together with eight known ones, were isolated. Among them, sarcophytolide $\mathrm{M}$, sarcophytolide I, sarcophytolide J, lobophytone $\mathrm{U}$, methyl tortuoate $\mathrm{B}$, and methyl sartortuoate exhibited cytotoxic effects against all or part of eight human cancer cell lines, including HepG2, HL-60, KB, LU-1, MCF7, SK-Mel2, and SW480. Notably, methyl sartortuoate (163) (Figure 20) exhibited strong cytotoxicity toward the HL-60 cell line, with an $\mathrm{IC}_{50}$ value of $7.93 \pm 2.08 \mu \mathrm{M}$ [129].
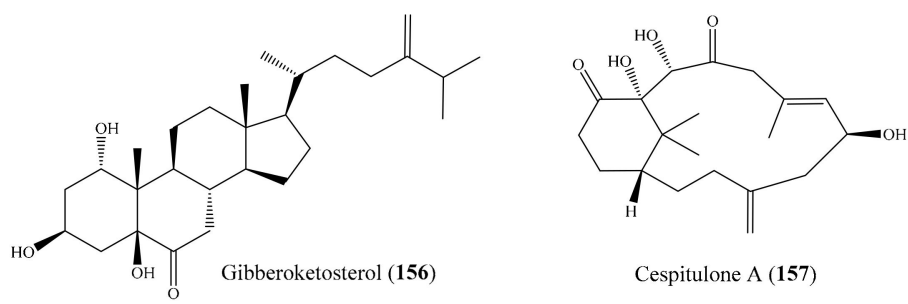

Cespitulone A (157)
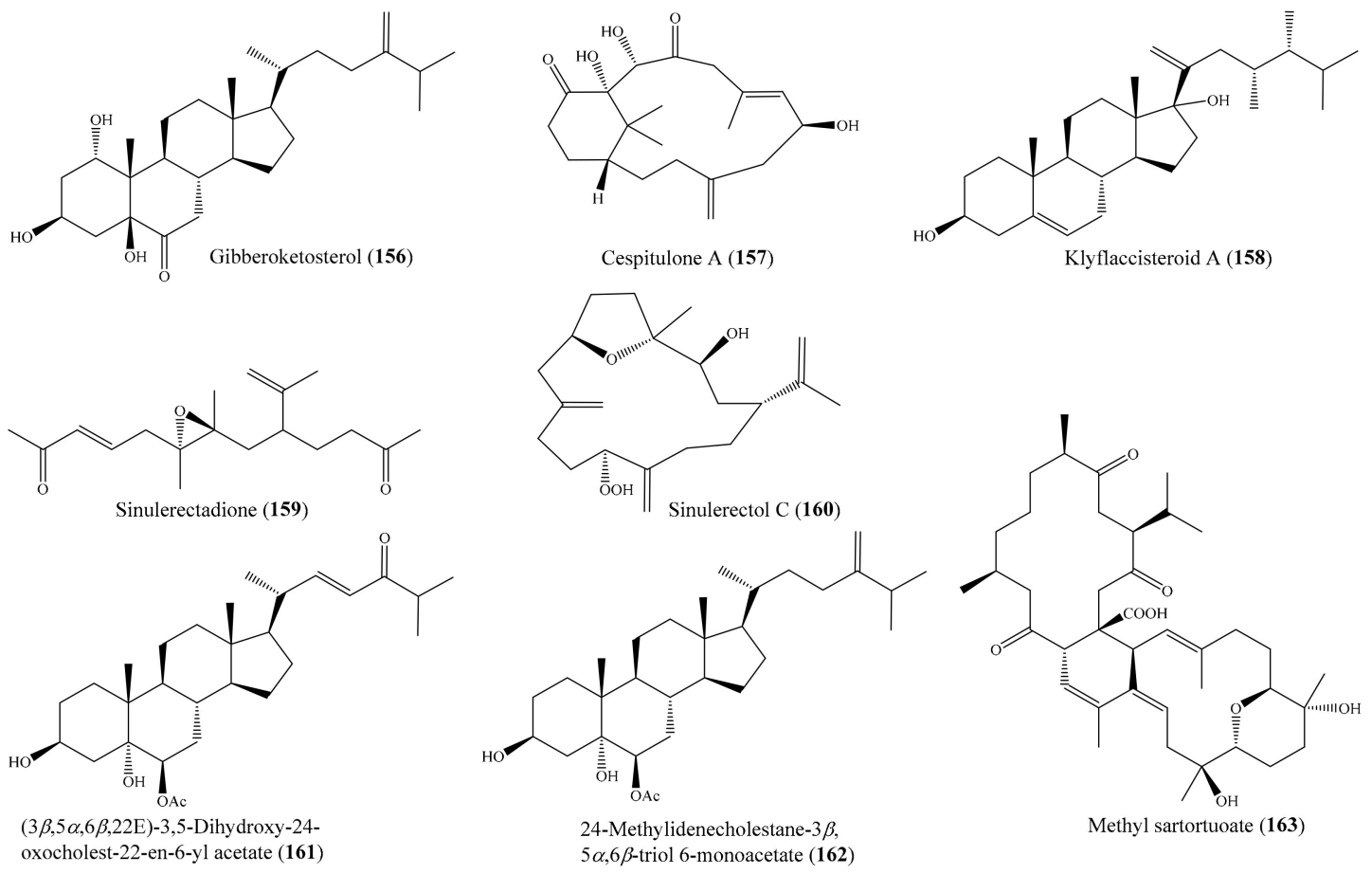

Figure 20. Chemical structures of 156-163.

From the coral Sarcophyton ehrenbergi, five new polyoxygenated cembranoids were obtained, of which compounds ehrenbergols D (164) and E (165) (Figure 21) showed significant cytotoxicity against the P-388 cancer cell line, with $\mathrm{EC}_{50}$ values of 2.0 and $3.0 \mu \mathrm{M}$, respectively, whereas three remaining polyoxygenated cembranoids showed no cytotoxicity. The structure-activity comparison of 
the cembranoids suggested that the conjugated double bonds at C-1/C-2 and C-3/C-4 were important for cytotoxicity against P-388 cells [130]. In another study, two new cembranes, columnariols A and B, were isolated from the coral Nephthea columnaris; however, only compound columnariol A (166) (Figure 21) exhibited moderate cytotoxicity toward LNCaP cells, with an $\mathrm{IC}_{50}$ value of $9.80 \mu \mathrm{g} / \mathrm{mL}$ $(30.4 \mu \mathrm{M})$ [131]. Chemical investigation of the coral Umbellulifera petasites led to the isolation of three new steroids, along with eight known steroids (see Section 2.1). Among them, compound petasitosterones A-C (167, 68, 70) (Figures 8 and 21) and 5 $\alpha$-pregna-1,20-dien-3-one (69) (Figure 8) displayed inhibitory activity against the proliferation of a limited panel of cancer cell lines (K-562, MOLT-4, and DLD-1), with $\mathrm{IC}_{50}$ values ranging from $5.8 \pm 1.7$ to $15.2 \pm 3.5 \mu \mathrm{g} / \mathrm{mL}(19.5 \pm 5.7$ to $33.3 \pm 7.7 \mu \mathrm{M})$ [79]. From the coral Litophyton mollis, seven new $4 \alpha$-methylated steroids and three known steroids were isolated. Of these, $4 \alpha, 24$-dimethyl-5 $\alpha$-cholest-24(28)-en-3 $\beta, 8 \beta, 18$-triol (168), (22E,24R)-4 $\alpha, 24$-dimethyl- $5 \alpha$-cholest-22-en-3 $\beta, 8 \beta, 11 \beta$-triol (169), nebrosteroid D (170), nebrosteroid A (171), and $23 \xi$-acetoxy- $4 \alpha, 24$-dimethyl- $5 \alpha$-cholest-24(28)-en-3 $\beta, 8 \beta, 11 \beta$ triol (172) (Figure 21) exhibited strong cytotoxic activity against K562 human chronic myelogenous leukemia cells, with $\mathrm{IC}_{50}$ values less than $10 \mu \mathrm{M}$, while at the same time they displayed low toxicity against healthy peripheral blood mononuclear cells. Furthermore, these compounds displayed moderate levels of toxicity against $\mathrm{A} 549$ cells, with $\mathrm{IC}_{50}$ values above $10 \mu \mathrm{M}$ [132]. In another study, Tsai et al. [133] isolated a new 10-demethylated steroid, a new 19-oxygenated steroid, and five known steroids from the coral Nephthea erecta. Interestingly, the compounds erectasteroid $F(\mathbf{1 7 3})$

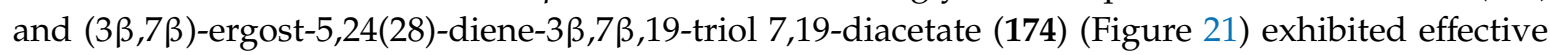
cytotoxicity against K562, Molt-4, Sup-T1, and U937 cell lines, with $\mathrm{IC}_{50}$ values of $6.5-14.0 \mu \mathrm{M}$, while 24-methyl-cholesta-5,24(28)-diene-3 $\beta, 19$-diol-7 $\beta$-monoacetate showed moderate cytotoxicity against K562, MOLT-4, and Sup-T1 cell lines, with IC $_{50}$ values of $11.2-19.9 \mu \mathrm{M}$. A preliminary structure-activity relationship of oxygenated steroids could be deduced from cytotoxicity bioassays. It was found that the presence of the acetoxy or hydroxy functional group at C-7 was critical for the cytotoxicity action of this class of compounds.

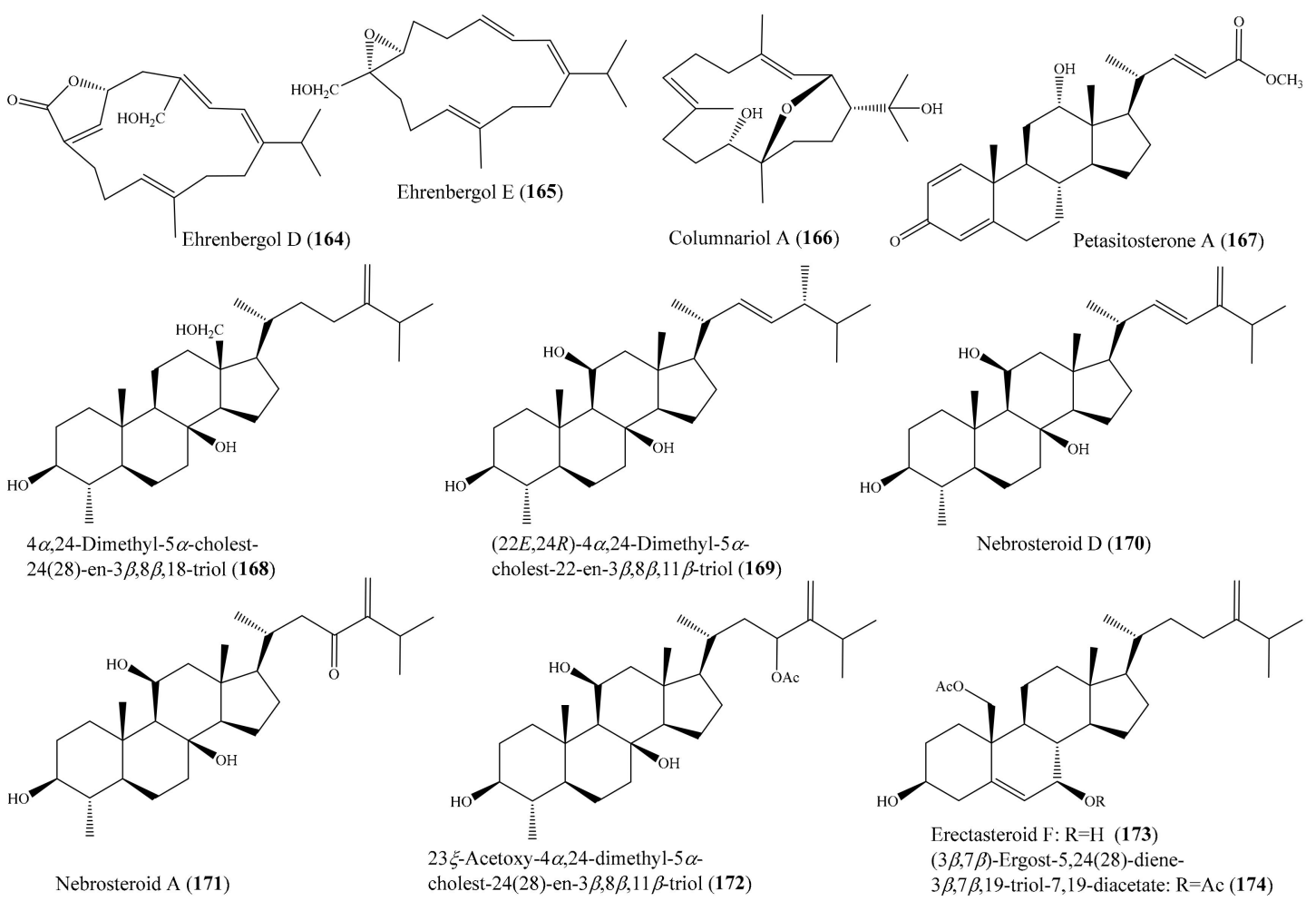

Figure 21. Chemical structures of 164-174. 
From the coral Pinnigorgia sp., three novel 9,11-secosterols, pinnigorgiols A-C (74-76) (Figure 9), were isolated (see Section 2.1), of which 74 and 75 decreased the cell viability of the HSC-T6 cell line, with $\mathrm{IC}_{50}$ values of $5.77 \pm 0.27$ and $7.89 \pm 0.52 \mu \mathrm{M}$, respectively. However, compound 76 displayed no effect on the same cell line, suggesting that the configuration of C-7 influenced the bioactivity [82]. Urda et al. [134] isolated two new xenicanes, protoxenicins A (175) and B (176) (Figure 22), from the coral Protodendron repens. Interestingly, both of the $\mathbf{1 7 5}$ and $\mathbf{1 7 6}$ xenicanes displayed significant cytotoxic activity against the NSLC A-549, HT-29, and MDA-MB-231 (breast) cancer cell lines, with GI 50 values of $0.6-6.3 \mu \mathrm{M}$. Doxorubicin was used as a positive control, with $\mathrm{GI}_{50}$ values of $0.2,0.3$, and $0.2 \mu \mathrm{M}$, against MDA-MB-231, HT-29, and NSLC A549, respectively. Chemical investigation of the coral Sarcophyton glaucum afforded 5 new isoprenoids along with 10 known compounds. Among them, the compound sarcomilasterol (177) (Figure 22) exhibited cytotoxicity effects against the MDA-MB-231, MOLT-4, SUP-T, and U-937 cell lines, with $\mathrm{IC}_{50}$ values of $6.7-17.7 \mu \mathrm{g} / \mathrm{mL}(15.0-39.5 \mu \mathrm{M})$, while the compound sarcoaldesterol B (178) (Figure 22) also showed cytotoxicity against the HepG2, MDA-MB-231, and A-549 cell lines, with $\mathrm{IC}_{50}$ values of $9.7-15.8 \mu \mathrm{g} / \mathrm{mL}(21.6-35.1 \mu \mathrm{M})$ [135]. In another study, Mohammed et al. [136] isolated five sterols and three sesquiterpenes from the coral Sinularia terspilli, of which the compounds ergost-24(28)-ene- $3 \beta, 5 \alpha, 6 \beta$-triol (179), ergost-24(28)-ene- $1 \alpha, 3 \beta, 5 \alpha, 6 \beta, 11 \alpha$ pentol (180), alismol (181), and (1S,4S,5S,10R)-4,10-guaianediol (182) (Figure 22) exhibited potent cytotoxic activity against the HL60 and $\mathrm{K} 562$ cell lines, with $\mathrm{IC}_{50}$ values ranging from $0.002 \pm 0.001$ to $0.60 \pm 0.08 \mu \mathrm{M}$, respectively. It was noted that the compounds $\mathbf{1 7 9}$ and $\mathbf{1 8 0}$ exhibited strong cytotoxic activity against HL60 and K562 cells, with $\mathrm{IC}_{50}$ values of $0.002-0.004$ and $0.003-0.005 \mu \mathrm{M}$, respectively, compared to the positive control taxol, which showed IC $_{50}$ values of 0.0005 and $0.0023 \mu \mathrm{M}$ against HL60 and K562, respectively. From the coral Sinularia flexibilis, five new cembranoid-related diterpenoids, along with nine known compounds, were isolated. A bioassay showed that the compounds 11-dehydrosinulariolide (183), 11-epi-sinulariolide acetate (184) (Figure 22), 14-deoxycrassin, and sinulariolide exhibited cytotoxic activity toward the P-388 and K-562 cancer cell lines, with $\mathrm{IC}_{50}$ values ranging from $6.9 \mu \mathrm{M}$ to $26.7 \mu \mathrm{M}$. Notably, compound 183 showed selective cytotoxicity toward P-388, with an $\mathrm{IC}_{50}$ value of $9.3 \mu \mathrm{M}$, while compound 184 was found to show potent activity and selectivity toward the P-388 and HT-29 cancer cell lines, with $\mathrm{IC}_{50}$ values of 6.9 and $9.6 \mu \mathrm{M}$, respectively [137]. Compound 5-dehydrosinulariolide (=11-dehydrosinulariolide) (183) was also found to display cytotoxicity against the A549, HT-29, SNU-398, and Capan-1 cancer cell lines, with $\mathrm{IC}_{50}$ values ranging from 8.9 to $27.4 \mu \mathrm{M}$ [84]. It was noted that among all of the nine tested cembranoids (Wu et al. [84]), only those containing a seven-membered lactone exhibited cytotoxicity, suggesting that the $\alpha, \beta$-unsaturated seven-membered lactone might have been responsible for the activity. Moreover, compound 183 (Figure 22), with a carbonyl group at the C-5 position, displayed obviously stronger activity than $\mathbf{7 8}$ and $\mathbf{7 9}$ (Figure 9), whose structures only differed from $\mathbf{1 8 3}$ at the C-5 position, suggesting that the carbonyl at C-5 instead of the hydroxyl or acetoxyl group improved the cytotoxic activity [84]. 

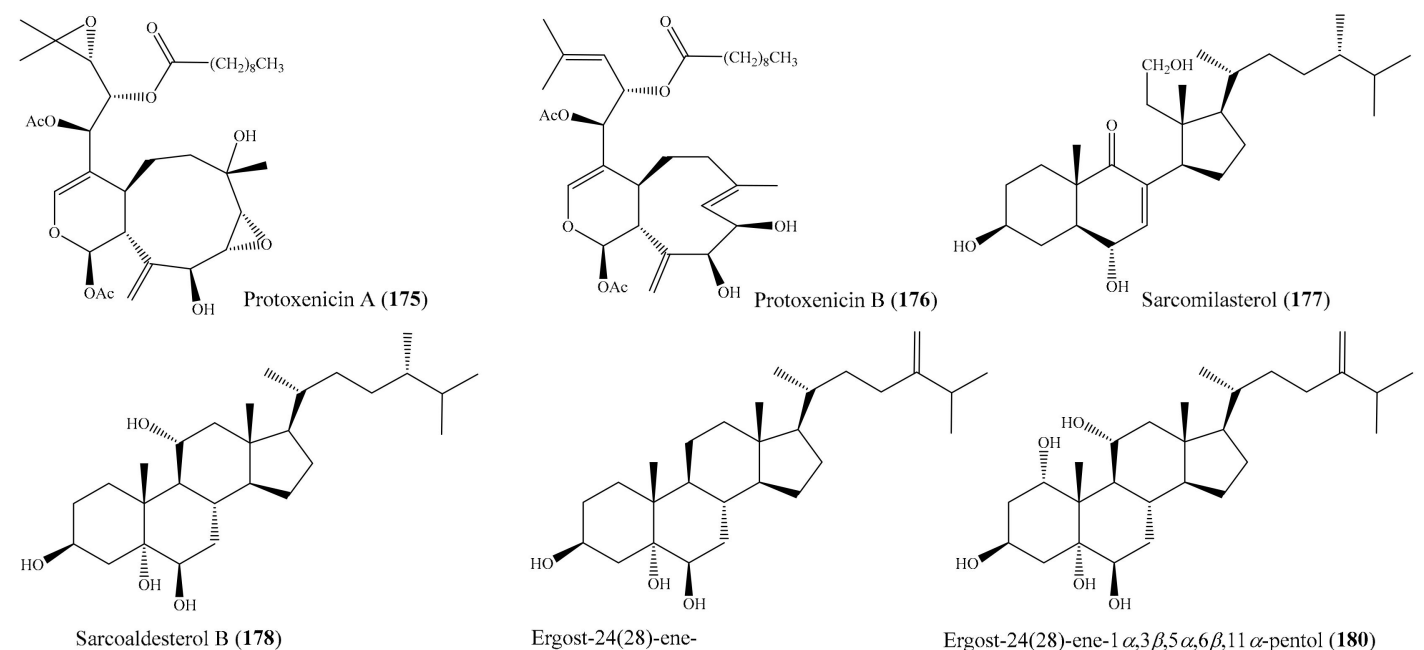

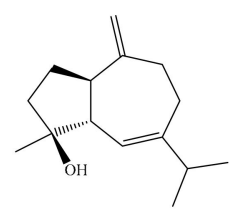

Alismol (181)

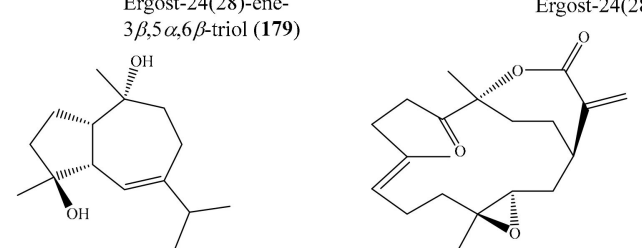

$1 S, 4 S, 5 S, 10 R-4,10$-Guaianediol (182)

11-Dehydrosinulariolide (183)

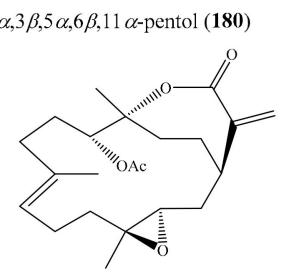

11-epi-Sinulariolide acetate (184)

Figure 22. Chemical structures of 175-184.

\subsection{Antimicrobial Compounds from Coral}

The emergence of antimicrobial resistance to existing antibiotics, the prevalence of multidrug-resistant bacteria, and the rapid development of cross-resistance with new drugs have become a serious public health problem. Antibiotic resistance is able to lead to high mortality and consequently impose huge healthcare costs $[138,139]$. Antibiotic-resistant pathogens can be acquired through mutation or horizontal transfer of a resistant gene [140], therefore compromising the effect of antibiotics [141]. Attempts to modify existing drugs are often not effective enough to overcome the mutation rate of pathogens and do not result in the introduction of new classes of antimicrobial agents [142]. In addition, the isolation of replicated known compounds significantly reduces the discovery rate of new antimicrobial compounds. Hence, efforts are aimed at discovering and producing efficient novel antibiotics [143]. The exploration of unexplored habitats and uncommon environments has become important for discovering novel therapeutic agents.

Antimicrobial resistance around the globe has led to an emerging demand for searches for novel antimicrobial drugs from marine environments. Recent investigations of corals have shown that many antimicrobial compounds have been isolated from coral (Supplementary Table S3): in particular, some compounds have exhibited strong activity against multiple pathogenic microorganisms. For example, two new rare pyrane-based cembranoids along with two known cembranoids and the aromadendrene sesquiterpenoid palustrol were isolated from the coral Sarcophyton trocheliophorum. Of these, the compounds sarcotrocheliol acetate (185) and sarcotrocheliol (186) (Figure 23) displayed potent antibacterial activity, especially against Staphylococcus aureus, Acinetobacter spp., and methicillin-resistant Staphylococcus aureus (MRSA), with minimal inhibitory concentrations (MICs) ranging from 1.53 to $4.34 \mu \mathrm{M}$, while cembrene-C (187) (Figure 23) exhibited potent antifungal activity against Aspergillus flavus and Candida albicans, with an MIC value of $0.68 \mu \mathrm{M}$. Furthermore, the compounds sarcophine (150) and palustrol (151) (Figure 19) showed lower antibacterial and antifungal activities compared to compounds 185-187. The antibacterial activity of $\mathbf{1 8 5}$ and $\mathbf{1 8 6}$ was comparable to that of the positive control ampicillin, whereas the antifungal activity of $\mathbf{1 8 7}$ against Aspergillus flavus and Candida albicans was stronger than that of the positive control amphotericin B $(\mathrm{MIC}=4.6 \mu \mathrm{M})$ [121]. From the coral Sarcophyton trocheliophorum, Zubair et al. [144] also isolated a new tetracyclic biscembrane hydrocarbon, 
trocheliane, along with two new cembranoid diterpenes, sarcotrocheldiols A and B. All of these new compounds showed antimicrobial activity, of which trocheliane (188) (Figure 23) exhibited strong antimicrobial activity against multiple reference microorganisms (Acinetobacter baumannii, Escherichia coli, Klebsiella pneumonia, Pseudomonas aeruginosa, Staphylococcus aureus, Staphylococcus epidermidis, and Streptococcus pneumoniae), with MIC values ranging from 4 to $6 \mu \mathrm{M}$. The antimicrobial activity of $\mathbf{1 8 8}$ was comparable to that of the positive control ampicillin, with MIC values ranging from 2.6 to $13 \mu \mathrm{M}$.

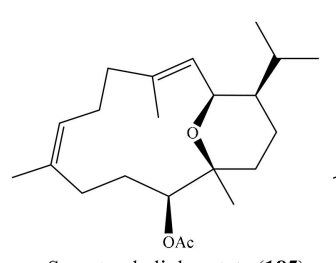

Sarcotrocheliol acetate (185)

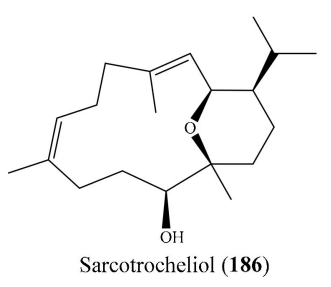

Sarcotrocheliol (186)

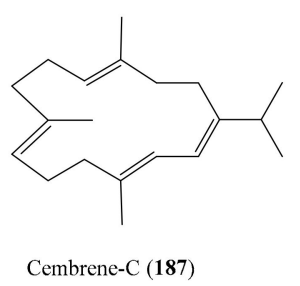

Cembrene-C (187)

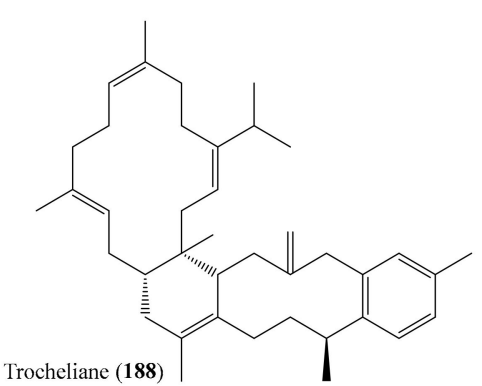

Figure 23. Chemical structures of 185-188.

\subsection{Antivirus Compounds from Coral}

Viruses are defined as a prodigious group of microorganisms causing assorted infectious diseases. Recent studies have reported the discovery of new antiviral agents, which generally inhibit the virus replication cycle by affecting the host cell factors for virus replication and/or viral elements [145]. Despite the development of antiviral agents over the past decades, patients suffering from viral infections are seriously influenced by treatment failure due to the emergence of recombinant viruses, drug resistance, and cell toxicity [146-148]. The high virulence of viruses and the lack of effective therapies have become a serious threat to public health. Moreover, the widespread occurrence of chronic viral infectious diseases and the rapid evolution and resistance of viruses to existing pharmaceuticals require ongoing exploration of new antivirus agents with higher efficiency and fewer side effects.

Besides antimicrobial activity, many compounds isolated from coral possess antivirus activity against different viruses (e.g., HCMV, H1N1, HIV-1) (Supplementary Table S4). Interestingly, several compounds show potent antiviral activity, indicating them as potential antiviral drugs. For example, three new cembranoids (108-110) (Figure 14) were isolated from the coral Sarcophyton ehrenbergi (see Section 2.2). Interestingly, ehrenbergol B (110) displayed strong antiviral activity against the human cytomegalovirus (HCMV), with an $\mathrm{IC}_{50}$ value of $5 \mu \mathrm{g} / \mathrm{mL}(13.2 \mu \mathrm{M})$, while the two remaining compounds, 108 and 109, displayed weak antiviral activity against human cytomegalovirus, with $\mathrm{IC}_{50}$ values of 60 and $46 \mu \mathrm{g} / \mathrm{mL}(160.4$ and $132.2 \mu \mathrm{M})$, respectively [104]. From the same coral species, two new diterpenoids, ehrenbergol C and acetyl ehrenberoxide B (189) (Figure 24), were also isolated. Notably, both of these compounds displayed strong antiviral activity toward the human cytomegalovirus, with an $\mathrm{EC}_{50}$ of 20 and $8.0 \mu \mathrm{g} / \mathrm{mL}(54.9$ and $22.0 \mu \mathrm{M})$, respectively [149]. In another study, Tseng et al. [150] reported the isolation of two new 9,11-secosteroids and two known norcembranoids from the coral Sinularia nanolobata; however, only sinuleptolide (190) (Figure 24) showed anti-HCMV activity, with an $\mathrm{ED}_{50}$ value of $1.92 \mu \mathrm{g} / \mathrm{mL}(5.5 \mu \mathrm{M})$. Ganciclovir was used as a positive control, with an $\mathrm{ED}_{50}$ of $0.12 \mu \mathrm{g} / \mathrm{mL}(0.47 \mu \mathrm{M})$. From the coral Litophyton arboreum, Ellithey et al. [116] also isolated nine compounds (see Section 2.2). Of these, the compounds alismol (181) (Figure 22), 7 $\beta$-acetoxy-24-methylcholesta-5-24(28)-diene-3,19-diol (142) (Figure 18), and erythro- $\mathrm{N}$-dodecanoyl-docosasphinga-(4E,8E)-dienine (191) (Figure 24) showed strong inhibitory activity against the HIV-1 PR virus, with $\mathrm{IC}_{50}$ values of $7.20 \pm 0.7,4.85 \pm 0.18$, and $4.80 \pm 0.92 \mu \mathrm{M}$, respectively. Chemical investigation of the coral Lobophytum crassum led to the isolation of a new seco-cembranoid, secocrassumol (192) (Figure 24). Interestingly, this compound showed strong antiviral activity against the human cytomegalovirus (HCMV), with an $\mathrm{IC}_{50}$ value of $5.0 \mu \mathrm{g} / \mathrm{mL}(12.7 \mu \mathrm{M})$ [151]. From the coral Sinularia verruca, 19 metabolites with diverse structures were isolated. Among them, 
compound (S)-4-hydroxy-5-methylene-2,3-dimethyl-4-pentylcyclopent-2-en-1-one (193) (Figure 24) showed effective protection against the cytopathic effects of HIV-1 infection, with $\mathrm{EC}_{50}$ values of 5.8-34 $\mu \mathrm{M}$ [152].
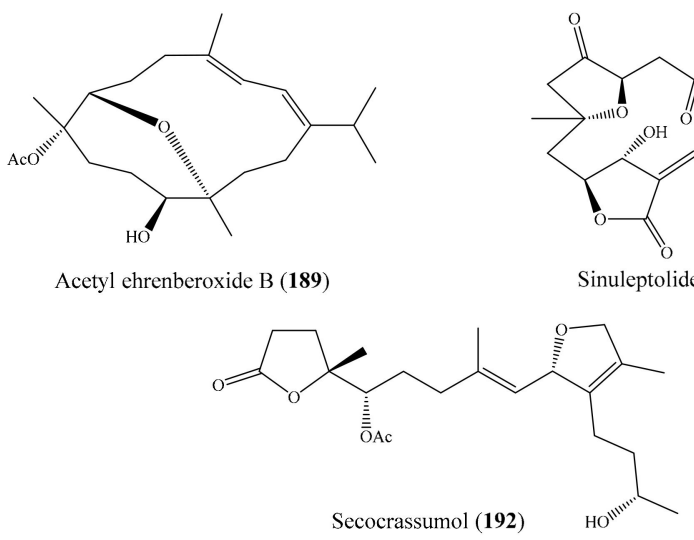

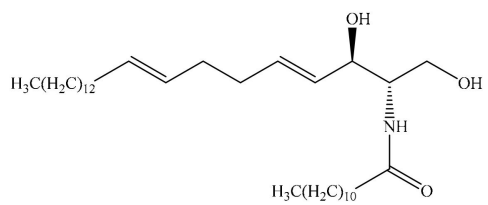

Erythro- $N$-dodecanoyl-docosasphinga-(4E,8E)-dienine (191)

Figure 24. Chemical structures of 189-193.

\subsection{Antifouling Compounds from Coral}

Biofouling is defined as the undesirable growth of microorganisms (e.g., bacteria, algae, and protozoa) and macroorganisms (e.g., barnacles, bryozoans, and tubeworms) on submerged surfaces [153]. Biofouling not only causes huge losses in marine technical and economic fields but also results in a series of environmental problems, such as the spread of invasive species [153-155]. The main strategies for the control of biofouling include the use of paints containing materials (copper, lead, mercury, arsenic, and organotins) or antifouling compounds to coat the substrata [156,157]. However, these antifouling compounds have raised many environmental issues because of their toxicities toward nontarget organisms [158]. For example, organotin compounds and alternative antifouling biocides such as Irgarol 1051 and diuron have been prohibited by the International Maritime Organization and many European countries because of the increasing evidence of their environmental risks $[159,160]$. Thus, there is urgent demand for a search for novel antifouling compounds with high efficiency and low/nontoxicity.

The chemical and bioactive investigation of coral has resulted in the isolation of antifouling compounds (Supplementary Table S5), of which several compounds exhibit potent activities. From the coral Sinularia sp., six new cyclopentenone derivatives, sinularones A-F, and three new furanones, sinularones G-I, together with a known butanolide, were isolated. Compound (S)-4-hydroxy-2,3-dimethyl-4-pentyl- $\gamma$-lactone (194) (Figure 25) showed potent antifouling activities against the barnacle Balanus amphitrite, with an $\mathrm{EC}_{50}$ of $3.84 \mu \mathrm{g} / \mathrm{mL}(19.4 \mu \mathrm{M})$, whereas the compound sinularones A, B, and F-I showed moderate antifouling activities against the barnacle Balanus amphitrite, with $\mathrm{EC}_{50}$ values $>10 \mu \mathrm{g} / \mathrm{mL}$. It was noted that the compounds sinularone $\mathrm{A}$ and $\mathrm{B}$ and sinularones $\mathrm{G}-\mathrm{I}$ showed potent inhibition, with $\mathrm{EC}_{50}$ values lower than the standard requirement $\left(\mathrm{EC}_{50}<25 \mu \mathrm{g} / \mathrm{mL}\right.$ ), with regard to the efficacy level of natural antifouling agents as established by the U.S. Navy program [161]. A primary discussion of the structure-activity relationship suggested that $\alpha, \beta$-unsaturated 2,3-dimethyl- $\gamma$-lactone is a functional unit for anti-barnacle [162]. In another study, 14 new asteriscane-type sesquiterpenoids, capillosananes $\mathrm{A}-\mathrm{N}$; four new seco-asteriscanes, capillosananes $\mathrm{O}-\mathrm{R}$; and (-)-sinularone A and sinularone A were obtained from the coral Sinularia capillosa. Interestingly, capillosanane A (195) (Figure 25) exhibited potent antifouling activity against Balanus amphitrite, with an $\mathrm{IC}_{50}$ value of $9.70 \mu \mathrm{M}$. In addition, it was found that the configuration at C-9 may play a key role in antifouling activity [163]. A subsequent chemical investigation of the coral Sinularia rigida afforded 12 new cembranoids, sinulariols $T-Z$ and $Z_{1}-Z_{5}$, together with a known analogue. Among them, the compounds sinulariol $Z$ (196) and (2E,7E)-4,11-dihydroxy-1,12-oxidocembra-2,7-diene (197) (Figure 25) showed potent antifouling activity 
against the barnacle Balanus amphitrite, with $\mathrm{IC}_{50}$ values of 4.57 and $4.86 \mu \mathrm{g} / \mathrm{mL}(14.2$ and $15.1 \mu \mathrm{M})$, and moderate inhibition against Bugula neritina, with $\mathrm{IC}_{50}$ values of 12.34 and $13.48 \mu \mathrm{g} / \mathrm{mL}$ ( 38.3 and $41.9 \mu \mathrm{M}$ ), respectively. Analyses of the primary structure-activity relationship revealed functional groups and olefinic geometry affecting antifouling activity. Active compound 197 was a C-19 dehydroxylated sinulariol D, whereas sinulariol D and its C-4 epimer sinulariol F exhibited weak inhibitory activity against $B$. amphitrite and $\mathrm{Bu}$. neritina, suggesting that $\mathrm{OH}-19$ dramatically decreased the inhibition in a 1,12-epoxy pattern. The similar data were observed in comparison to the antifouling activity of 196 and sinulariols $\mathrm{H}$ and J. With 11,12-epoxy analogues, sinulariol P exhibited stronger inhibitory activity against B. neritina than sinulariols $\mathrm{L}$ and $\mathrm{O}$ did, indicating that the 7E geometry was better than 7Z [164]. A novel unusual pentacyclic hemiacetal sterol, nephthoaceta, along with two unusual pentacyclic steroids, were also isolated from the coral Nephthea sp. A biological examination indicated that the compound nephthoaceta (198) (Figure 25) exhibited significant antifouling against Bugula neritina larvae, with an $\mathrm{EC}_{50}$ value of $2.5 \mu \mathrm{g} / \mathrm{mL}(6.3 \mu \mathrm{M})$. Compared to 198, its two acetyl derivatives possessed an additional acetyl group on the tetrahydropyran ring, and their huge differences in antifouling activity compared to 198 revealed that the free hydroxyl group at the acetal carbon C-18 may have been very important in the observed antifouling activity [165]. In another study, Zhang et al. [166] isolated two new unusual cholestane derivatives along with two new pregnane derivatives from the coral Subergorgia suberosa. Interestingly, compounds 16,22-epoxy-20 $\beta, 23 S$-dihydroxycholest-1-ene-3-one (199) (Figure 25) and 20ß,23S-dihydroxycholest-1-ene-3,22-dione exhibited antifouling activity against Balanus amphitrite larvae settlement, with $\mathrm{EC}_{50}$ values of 5.3 and $14.5 \mu \mathrm{g} / \mathrm{mL}(12.3$ and $33.7 \mu \mathrm{M})$, respectively, whereas two new pregnane derivatives, 15b,17a-dihydroxypregna-4,6-diene-3,20-dione and 11a-hydroxypregna-4-ene-3,6,20-trione, showed no antifouling activity at a concentration of $25 \mu \mathrm{g} / \mathrm{mL}$, an efficacy level for natural antifoulants set by the U.S. Navy program. Compared to compound 20ß,23S-dihydroxycholest-1-ene-3,22-dione, compound 199 possesses a tetrahydrofuran moiety, which might be important for its potent inhibitory activity against the settlement of B. amphitrite larvae. Interestingly, this assumption is in good agreement with a previous report, where the furan moiety was indicated to be an important functional group responsible for antifouling activity [167]. Wang et al. [168] also isolated seven cembrane diterpenes from the coral Sinularia flexibilis. It is notable that all compounds except sinularin showed antifouling activity. In particular, compound (-)14-deoxycrassin (200) (Figure 25) exhibited remarkable antifouling activity against the two biofoulers B. amphitrite and B. albicostatus, with $\mathrm{EC}_{50}$ values of 3.90 and $21.26 \mu \mathrm{g} / \mathrm{mL}(12.3$ and $66.9 \mu \mathrm{M})$, respectively.
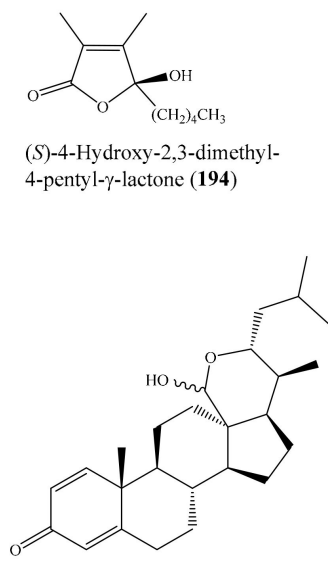

Nephthoaceta (198)
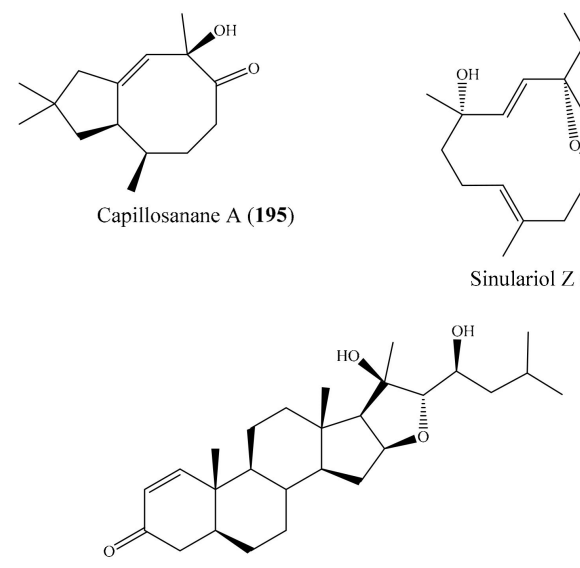

16,22-Epoxy-20 $\beta, 23 S$-dihydroxycholest-1-ene-3-one (199)

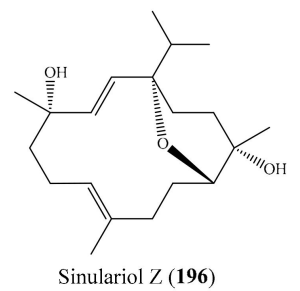

-oxidocembra-2,7-diene (197)

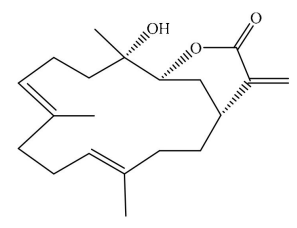

(-)14-Deoxycrassin (200)

Figure 25. Chemical structures of 194-200.

\subsection{Other Bioactive Compounds from Coral}

Besides the above biological activities mentioned, coral-derived compounds show other bioactivities, such as acetylcholinesterase inhibitory, polymerase proofreading-associated polyposis 
(PPAP) transcriptional, heme polymerization inhibitory, PTP 1B inhibitory, and DPPH radical scavenging activities (Supplementary Table S6). For example, from the coral Lobophytum laevigatum, a new unusual sterol, lobophytosterol, and five known metabolites were isolated. Among them, compounds (22S,24S)-24-methyl-22,25-epoxyfurost-5-ene-3 $\beta, 20 \beta$-diol (201), (24S)-ergost5 -ene-3 $\beta, 7 \alpha$-diol (202), and pregnenolone (203) (Figure 26) significantly upregulated PPAR transcriptional activity dose-dependently in Hep-G2 cells. At a concentration of $1 \mu \mathrm{M}$, compounds 201-203 enhanced PPAR transcriptional activity by 1.4-, 1.2-, and 1.6-fold, respectively [169]. Chemical investigation of the coral Sarcophyton trocheliophorum Marenzeller yielded two new sarsolenane diterpenes and two new capnosane diterpenes, together with the known analogue. Of these, compounds sarsolilide A (204) (Figure 26) and sarsolilide B exhibited inhibitory activity against protein tyrosine phosphatase $1 \mathrm{~B}$ (PTP1B), with $\mathrm{IC}_{50}$ values of $6.8 \pm 0.96$ and $27.1 \pm 2.6 \mu \mathrm{M}$, respectively, representing the first report of PTP1B inhibitory activity for capnosane diterpenes. Interestingly, compound 204 showed remarkable inhibitory activity similar to that of the positive control (oleanolic acid), with an $\mathrm{IC}_{50}$ of $2.6 \pm 0.4 \mu \mathrm{M}[170]$.

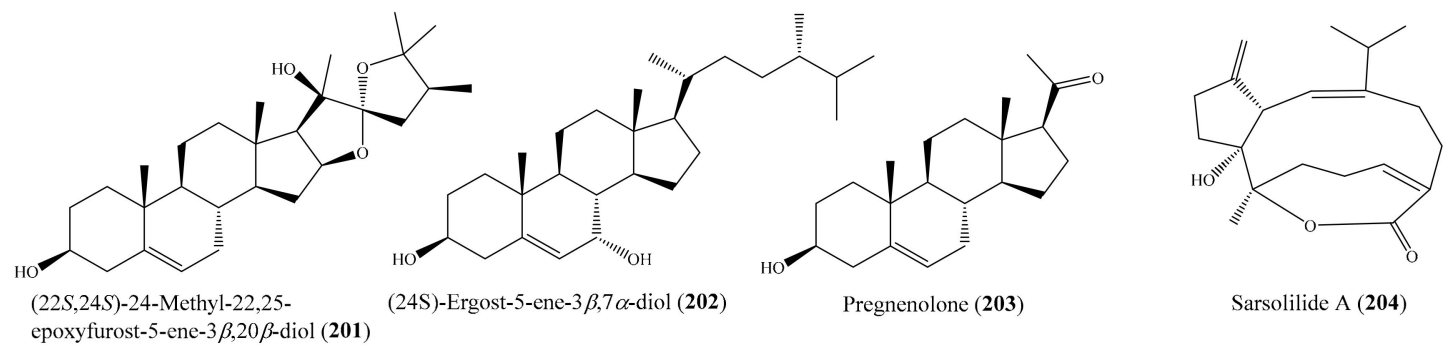

Figure 26. Chemical structure of 201-204.

\section{Bioactive Compounds from Coral-Associated Microorganisms}

\subsection{Anti-Inflammatory and Cytotoxic Compounds from Coral-Associated Microorganisms}

Coral harbors a high diversity of associated microorganisms, and many coral-associated microorganisms are found to produce anti-inflammatory and cytotoxic compounds (Supplementary TableS7). Several of them show potent activity, presenting as promising compounds for the development of new anti-inflammatory and cytotoxic agents.

From the coral-derived fungus Aspergillus terreus, four new butenolide derivatives and six known ones were obtained. Of these, compounds versicolactone B (205) (Figure 27), 3'-isoamylene butyrolactone IV, and butyrolactone I showed anti-inflammatory activity by inhibiting NO production in LPS-induced RAW 264.7 mouse macrophages. In particular, 205 exhibited an even stronger inhibition of NO production than the positive control indomethacin, presenting itself as a promising lead compound for the development of new anti-inflammatory agents [171].

From Alternaria sp. ZJ-2008003, a fungus obtained from soft coral Sarcophyton sp., five new hydroanthraquinone derivatives, tetrahydroaltersolanols $\mathrm{C}-\mathrm{F}$ and dihydroaltersolanol A; five new alterporriol-type anthranoid dimers, alterporriols $\mathrm{N}-\mathrm{R}$; along with seven known analogues were isolated. Interestingly, the anthraquinone derivative altersolanol C (206) (Figure 27) exhibited strong cytotoxicity against five cancer cell lines (HCT-116, MCF-7/ADR, PC-3, HepG2, and Hep3B), with IC $_{50}$ values between 2.2 and $8.9 \mu \mathrm{M}$, whereas the hydroanthraquinone derivatives, tetrahydroaltersolanols C-F, dihydroaltersolanols A and B, altersolanol B, altersolanol L, and ampelanol, with an oxidized C-10 and a reduced C-9 fragment, were inactive. These results suggested that the paraquinone moiety was important for cytotoxic activity. The cytotoxic activity of $\mathbf{2 0 6}$ against HCT-16 and MCF-7/ADR cells was comparable to that of the positive control epirubicin ( $\mathrm{IC}_{50}$ values of 0.82 and $1.65 \mu \mathrm{M}$, respectively). Furthermore, among the alterporriol-type dimers, alterporriol P (207) (Figure 27) was found to possess cytotoxicity against PC-3 and HCT-116 cell lines, with $\mathrm{IC}_{50}$ values of 6.4 and $8.6 \mu \mathrm{M}$, respectively [172]. 

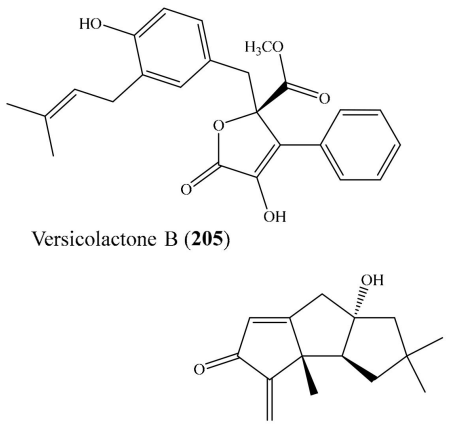

Chondrosterin A (208)

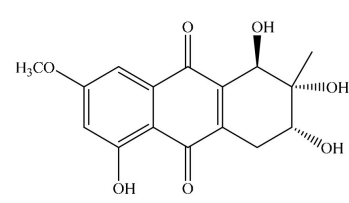

Altersolanol C (206)

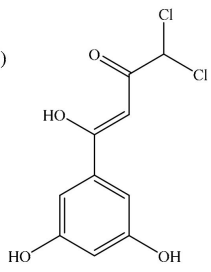

Strepchloritide A (209)

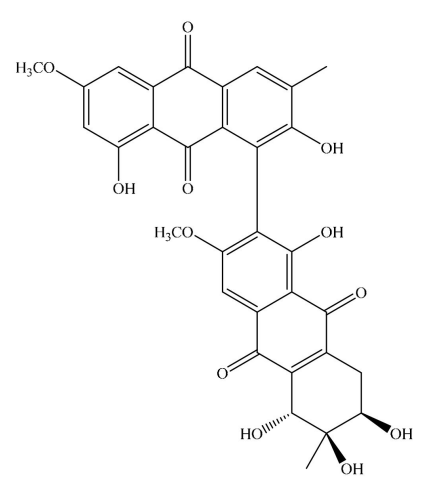

Alterporriol P (207)<smiles>COC1=C(OC)C(=O)c2c(cc3c(c2O)C[C@H](C)[C@@H](O)[C@@H]3O)C1=O</smiles>
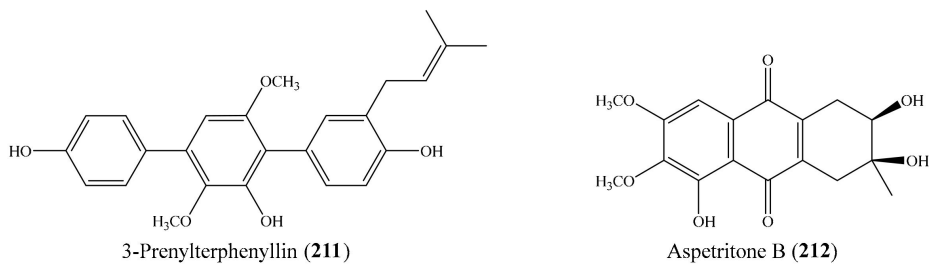

Figure 27. Chemical structures of 205-212.

From the fungus Chondrostereum sp., which was isolated from the soft coral Sarcophyton tortuosum, $\mathrm{Li}$ et al. [173] afforded five new triquinane-type sesquiterpenoids, chondrosterins A-E, and a known sesquiterpenoid, hirsutanol C. Among them, chondrosterin A (208) (Figure 27) showed significant cytotoxic activities against cancer lines A549, CNE2, and LoVo, with $\mathrm{IC}_{50}$ values of 2.45, 4.95, and $5.47 \mu \mathrm{M}$, respectively. In another study, two new chlorinated polyketides, strepchloritides A and B; three thiazole derivatives, watasemycin A, pulicatin $\mathrm{G}$, and aerugine; and pyrrole-2-carboxamide, furan-2-carboxamide, and 1-(3,5-dihydroxyphenyl)ethanone were isolated from the soft coral-associated actinomycetes strain Streptomyces sp. OUCMDZ-1703. Interestingly, the new compounds strepchloritide A (209) (Figure 27) and strepchloritide B displayed cytotoxicity against the MCF-7 cells, with $\mathrm{IC}_{50}$ values of 9.9 and $20.2 \mu \mathrm{M}$, respectively [174]. Chemical investigation of the coral-derived fungus Aspergillus tritici SP2-8-1 obtained three novel compounds, 4-methyl-candidusin A, aspetritone A, and aspetritone B, together with 15 known compounds. Among them, compounds aspetritone A (210) and 3-prenylterphenyllin (211) (Figure 27) exhibited potent cytotoxic activities against human cancer cell lines HeLa, A549, and HepG2, with $\mathrm{IC}_{50}$ values from $2.10 \pm 0.20$ to $3.87 \pm 0.74 \mu \mathrm{M}$, whereas aspetritone B (212) (Figure 27) also showed significant cytotoxicity toward cancer cell lines A549 and HepG2, with $\mathrm{IC}_{50}$ values of $4.67 \pm 0.60$ and $8.57 \pm 0.83 \mu \mathrm{M}$, respectively. It was noted that the cytotoxicity of $\mathbf{2 1 0}$ and $\mathbf{2 1 2}$ against the Hep G2 cells was comparable to that of the positive control doxorubicin. Preliminary structure-activity relationship studies implied that the prenylation of terphenyllin or candidusin and the tetrahydrobenzene moiety in anthraquinone derivatives may be important for their bioactivity [175].

\subsection{Antimicrobial Compounds from Coral-Associated Microorganisms}

Many compounds from coral-associated microorganisms have been found to exhibit antimicrobial activity (Supplementary Table S8). Several of them possess potent activity and present as potential antimicrobial drugs. From a coral-associated actinomycetes strain, Streptomyces sp. OUCMDZ-1703, two new chlorinated polyketides and three thiazole derivatives, along with pyrrole-2-carboxamide, furan-2-carboxamide, and 1-(3,5-dihydroxyphenyl)ethanone, were isolated. Notably, compounds watasemycin A (213) and aerugine (214) (Figure 28) were first found to exhibit strong antimicrobial activity against $S$. aureus (ATCC25923) and three clinical strains of methicillin-resistant Staphylococcus aureus (MRSA082, MRSA111, and MRSA234), with MIC values of 1.95-7.81 $\mu \mathrm{g} / \mathrm{mL}$ (5.5-37.4 $\mu \mathrm{M})$ [174]. In another study, a new chlorinated benzophenone derivative, $( \pm)$-pestalachloride $\mathrm{D}(\mathbf{2 1 5})$, along with 
a related analogue, $( \pm)$-pestalachloride C (216) (Figure 28), were isolated from the fungus Pestalotiopsis sp., which is associated with the soft coral Sarcophyton sp. Bioassay results indicated that both compounds 215 and 216 exhibited antibacterial activity against Escherichia coli, Vibrio anguillarum, and Vibrio parahaemolyticus, with MIC values of 5.0, 10.0, and $20.0 \mu \mathrm{M}$, respectively [176]. Zheng et al. [177] reported the isolation of one new phenylalanine derivative, 4 '-OMe-asperphenamate, along with one known phenylalanine derivative, asperphenamate, and two new cytochalasins, aspochalasin A1 and cytochalasin Z24, as well as eight known cytochalasin analogues from Aspergillus elegans ZJ-2008010, a fungus obtained from soft coral Sarcophyton sp. Compounds 4'-OMe-asperphenamate (217) and asperphenamate (218) (Figure 28) showed selective antibacterial activity against $S$. epidermidis, with MIC values of $10 \mu \mathrm{M}$ for each, whereas compound aspochalasin I (219) (Figure 28) showed antibacterial activity against $S$. epidermidis and S. aureus, with MIC values of 20 and $10 \mu \mathrm{M}$, respectively: aspochalasin D (220) (Figure 28) showed antibacterial activity toward a broad spectrum of pathogenic bacteria (S. epidermidis, S. aureus, E. coli, and B. cereus), with MIC values of $10 \mu \mathrm{M}$. Chemical investigation of the coral-derived fungus Scopulariopsis sp. afforded six known dihydroquinolin-2-one-containing alkaloids. Notably, compound 6-deoxyaflaquinolone E (221) (Figure 28) exhibited extensive antibacterial activity against the tested bacteria, especially $S$. aureus, B. cereus, V. parahaemolyticus, $N$. brasiliensis, and P. putida, with MIC values of $0.78,1.56,6.25,0.78$, and $1.56 \mu \mathrm{M}$, respectively [178]. The antimicrobial activity of 221 against $S$. aureus and $N$. brasiliensis was comparable to that of the positive control ciprofloxacin, with MIC values of 0.625 and $0.625 \mu \mathrm{M}$, respectively. In 2017, Wang et al. [175] isolated three novel compounds together with 15 known compounds from a coral-derived microorganism, Aspergillus tritici SP2-8-1. Of these, the compounds aspetritone A (210) (Figure 27) and 4-methyl-3"-prenylcandidusin A (222) (Figure 28) exhibited better activities against the methicillin-resistant strains of $S$. aureus (MRSA) ATCC 43300 and MRSA CGMCC 1.12409 than the positive control chloramphenicol did. Compound 222 displayed stronger anti-MRSA than $\mathbf{2 1 0}$ and showed stronger antibacterial activities against strains of Vibrio vulnificus, Vibrio rotiferianus, and Vibrio campbellii than the other compounds did. From Alternaria sp. ZJ-2008003, a fungus obtained from soft coral Sarcophyton sp., three antimicrobial compounds (206 (Figure 27), macrosporin, and alterporriol C) were isolated (Section 3.1). Interestingly, the antimicrobial activity of compound 206 against E. coli was comparable to that of the positive control ciprofloxacin $(\mathrm{MIC}=0.62 \mu \mathrm{M})[172]$.
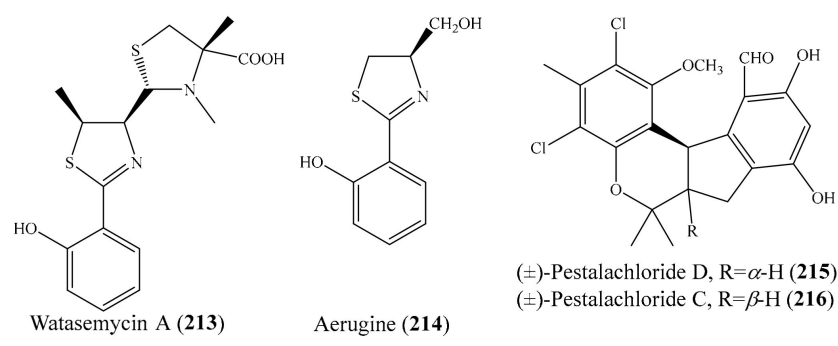

( \pm )-Pestalachloride $\mathrm{D}, \mathrm{R}=\alpha$ - $\mathrm{H}(\mathbf{2 1 5})$ $( \pm)$-Pestalachloride $\mathrm{C}, \mathrm{R}=\beta-\mathrm{H}(\mathbf{2 1 6})$

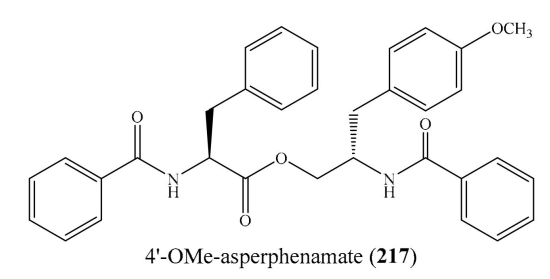
Aerugine (214)<smiles>O=C(N[C@@H](Cc1ccccc1)C(=O)OC[C@@H](Cc1ccccc1)NC(=O)c1ccccc1)c1ccccc1</smiles>

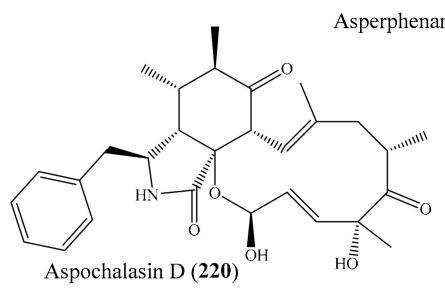
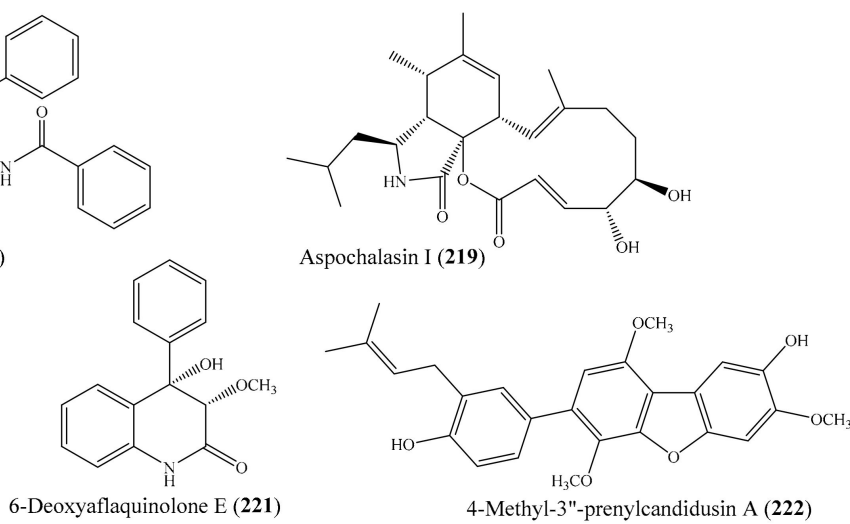

Figure 28. Chemical structures of 213-222. 


\subsection{Antivirus Compounds from Coral-Associated Microorganisms}

In addition to antimicrobial activity, several antivirus metabolites have been isolated from coral-derived microorganisms (Supplementary Table S9); however, these compounds exhibited moderate activity. For example, from Alternaria sp. ZJ-2008003, obtained from the soft coral Sarcophyton sp., five new hydroanthraquinone derivatives and five new alterporriol-type anthranoid dimers, along with seven known analogues, were isolated. Among them, only three compounds (tetrahydroaltersolanol C, alterporriol $Q$, and alterporriol C) exhibited antiviral activity against the porcine reproductive and respiratory syndrome virus (PRRSV), with $\mathrm{IC}_{50}$ values of 65,22 , and $39 \mu \mathrm{M}$, respectively [172]. In another study, Jia et al. [179] isolated a new phthalide derivative, pestalotiolide $\mathrm{A}$, along with three known analogues and 5'-O-acetyl uridine from fungus Pestalotiopsis sp. ZJ-2009-7-6 isolated from a soft coral Sarcophyton sp. Compared to the positive control ribavirin $\left(\mathrm{IC}_{50}=418.0 \mu \mathrm{M}\right)$, pestalotiolide A exhibited anti-EV71 activity, with an $\mathrm{IC}_{50}$ value of $27.7 \mu \mathrm{M}$, whereas compound 7-hydroxy-5-methoxy-4,6-dimethyl-7-O- $\beta$-D-glucopyranosyl-phthalide showed strong antiviral activities against EV71, RSV, and HSV-1, with $\mathrm{IC}_{50}$ values of 51.6, 25.6, and $63.9 \mu \mathrm{M}$, respectively. Furthermore, compound 7-hydroxy-5-methoxy-4,6-dimethylphthalide displayed pronounced antiviral activities against Cox-B3 and RSV, with $\mathrm{IC}_{50}$ values of $19.6 \mu \mathrm{M}$ and $21.0 \mu \mathrm{M}$, which were stronger than those of the positive control ribavirin, with $\mathrm{IC}_{50}$ values of 39.0 and $78.0 \mu \mathrm{M}$, respectively. Compound 5'-O-acetyl uridine and 7-hydroxy-5-methoxy-4,6-dimethyl-7-O- $\alpha$-L-rhamnosyl-phthalide shared similar antiviral activities, with pronounced antiviral activities against EV71. Analyses of the structure-activity relationship of the phthalide derivatives revealed that the glycosidation of 7-OH significantly increased anti-EV71 activity and that the acetylation of $6^{\prime}-\mathrm{OH}$ increased anti-EV71 activity. Furthermore, the acetoxy group at $\mathrm{C}^{\prime} 6^{\prime}$ had a positive contribution to anti-EV71 activity.

\subsection{Antifouling Compounds from Coral-Associated Microorganisms}

Several antifouling secondary metabolites have been isolated and identified from coral-derived microorganisms (Supplementary Table S10), including some potent active compounds. From Aspergillus elegans ZJ-2008010, a fungus obtained from soft coral Sarcophyton sp., Zheng et al. [177] isolated one new phenylalanine derivative, one known phenylalanine derivative, two new cytochalasins, as well as eight known cytochalasin analogues. Among them, aspochalasin D (220) (Figure 28) and H-J showed antifouling activity against a larval settlement of the barnacle Balanus amphitrite, with $\mathrm{EC}_{50}$ values ranging from 6.2 to $37 \mu \mathrm{M}$. Compound 220, bearing an $\alpha, \beta$-unsaturated ketone moiety, displayed considerably stronger activity than aspochalasin J, with an $\alpha, \beta$-unsaturated lactone moiety, implying the importance of an electrophilic $\alpha, \beta$-unsaturated carbonyl moiety for the antifouling activity of these cytochalasins. In addition, compound 220 exhibited more activity than aspochalasin $\mathrm{H}$, suggesting that the double bond at C-19 and C-20 may be important in the antifouling activity of cytochalasins. A chemical investigation of the coral-associated fungus Penicillium sp. SCSGAF 0023, isolated from the coral Dichotella gemmacea, led to the isolation of two new polyketides, together with six known analogues. Notably, compounds 6,8,5' 6' -tetrahydroxy-3'-methylflavone (223), emodin (224) (Figure 29), citreorosein, and isorhodoptilometrin had significant antifouling activity against a Balanus amphitrite larvae settlement, with $\mathrm{EC}_{50}$ values of $6.7,6.1,17.9$, and $13.7 \mu \mathrm{g} / \mathrm{ml}(22.3,22.6,62.5$, and $43.6 \mu \mathrm{M})$, respectively. Besides, compounds 223 and 224 had low cytotoxicity, with an $\mathrm{LC}_{50} / \mathrm{EC}_{50}$ ratio $>14.9$ and $>16.5$, respectively [180]. It is noted that the standard requirement of an efficacious $\mathrm{EC}_{50}$ level for a natural antifoulant is $25 \mu \mathrm{g} / \mathrm{ml}$, which was established by the U.S. Navy program [161], and a compound with an $\mathrm{LC}_{50} / \mathrm{EC}_{50}$ ratio $>15$ is often considered to be a nontoxic antifouling compound [157]. The results indicated that 222 and $\mathbf{2 2 3}$ are promising natural antifoulants. In another study, Shao et al. [178] isolated six known dihydroquinolin-2-one-containing alkaloids from fungus Scopulariopsis sp. obtained from the coral Carijoa sp. Interestingly, five out of the six isolated compounds, aniduquinolone A (225), aflaquinolone A (226) (Figure 29), aflaquinolone D (227), 6-deoxyaflaquinolone E (221) (Figure 28), and aflaquinolone $F(228)$ (Figure 29), showed potent antifouling activity against a larval settlement of the barnacle Balanus amphitrite, with $\mathrm{IC}_{50}$ values from $17.5 \mathrm{pM}$ to $1.04 \mu \mathrm{M}$. Compounds 225 and 226 were 
found to be the most promising nontoxic antilarval settlement candidates. In particular, compound 225 has been the strongest antifouling compound in nature up to now, showing highly potent activity at a picomolar level $\left(\mathrm{EC}_{50}=17.5 \mathrm{pM}\right)$ and a very safe and high therapeutic ratio $\left(\mathrm{LC}_{50} / \mathrm{EC}_{50}=1200\right)$. Analyses of the structure-activity relationship of 225-227 indicated that the tetrahydrofuran ring at C-18 was more important for antifouling activity than the tetrahydrofuran ring at C-18. It was found that compounds 221 and 228, with $\alpha$ configurations of $\mathrm{OH}$ or $\mathrm{OCH}_{3}$ at C-3, exhibited 100-fold greater efficacy than aflaquinolone $\mathrm{G}$, with a $\beta$ configuration of $\mathrm{OH}$ at $\mathrm{C}-3$, thus suggesting that the configuration at $\mathrm{C}-3$ played an apparent role in the antifouling activity. However, there was no appreciable change in the antifouling efficacy between 221 and 228, implying that the methylation of $\mathrm{OH}$ at C-3 in $\mathbf{2 2 8}$ and $\mathbf{2 2 1}$ had very little effect on antifouling activity.

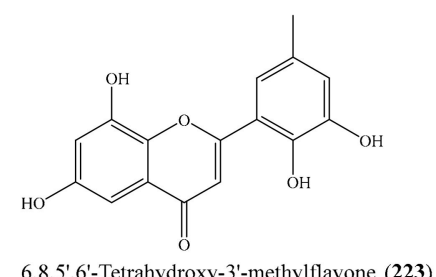

6,8,5',6'-Tetrahydroxy-3'-methylflavone (223)

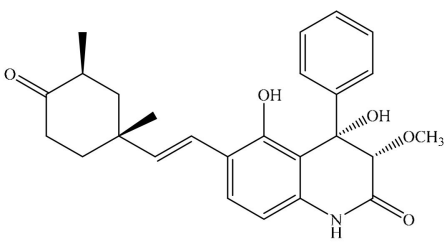

Aflaquinolone A (226)

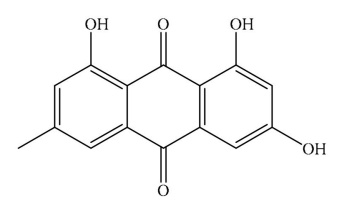

Emodin (224)

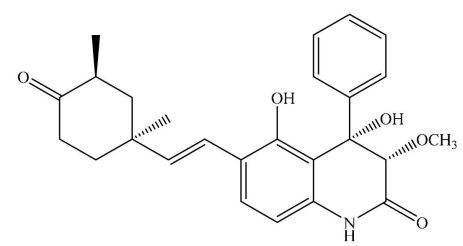

Aflaquinolone D (227)

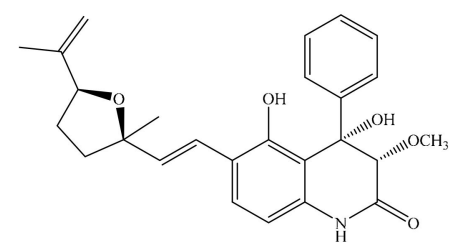

Aniduquinolone A (225)

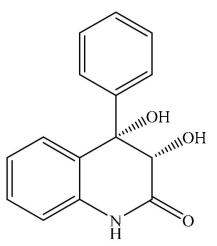

Aflaquinolone F (228)

Figure 29. Chemical structures of 223-228.

\subsection{Other Bioactive Compounds from Coral-Associated Microorganisms}

Apart from anti-inflammatory, cytotoxic, antimicrobial, antivirus, and antifouling activities, coral-derived microorganisms could produce protease inhibitory, lipid-lowering, $\alpha$-glucosidase, and antioxidant compounds (Supplementary Table S11). For example, from the fermentation broth of the coral-associated fungus Aspergillus versicolor LCJ-5-4, which was isolated from soft coral Cladiella sp., three new cyclopentapeptides, versicoloritides A-C; a new orcinol tetramer, tetraorcinol A; two new lactones, versicolactones $\mathrm{A}$ and $\mathrm{B}$; and three known metabolites were isolated. Among them, the compound tetraorcinol A showed moderate radical scavenging activity against the DPPH radical, with an $\mathrm{IC}_{50}$ value of $67 \mu \mathrm{M}$ [181]. In another study, Hawasa et al. [182] isolated five metabolites from the ethyl acetate extract of the coral-associated fungus Alternaria alternate, which was isolated from the coral Litophyton arboretum. Among them, the compounds alternar-iol-9-methyl ether, alternariol, and alternariol-9-methyl ether-3-O-sulphate showed inhibitory activity against HCV NS3-NS4A, with $\mathrm{IC}_{50}$ values of 32.2, 12.0, and $52.0 \mu \mathrm{g} / \mathrm{mL}(118.3,46.5$, and $148 \mu \mathrm{M})$, respectively. A chemical investigation of the coral-derived fungus Cladosporium sp. TZP-29 led to the isolation of two new C12 polyketides, cladospolides $\mathrm{E}$ and $\mathrm{F}$, together with four known derivatives. Interestingly, seco-patulolide A (229) and 11-hydroxy- $\gamma$-dodecalactone (230) (Figure 30) exhibited strong lipid-lowering activity in HepG2 hepatocytes, with $\mathrm{IC}_{50}$ values of 8.4 and $7.1 \mu \mathrm{M}$, respectively, while the compounds cladospolide $\mathrm{E}$ and seco-patulolide $C$ showed less activity, with $\mathrm{IC}_{50}$ values of 12.1 and $13.1 \mu \mathrm{M}$, respectively. The lipid-lowering activity of $\mathbf{2 2 9}$ and $\mathbf{2 3 0}$ was comparable to that of the positive control lovastatin, with an $\mathrm{IC}_{50}$ value of $8.1 \mu \mathrm{M}[183]$. 
<smiles>CC(O)C=CC(=O)CCCCCCC(C)O</smiles>

seco-Patulolide A (229)

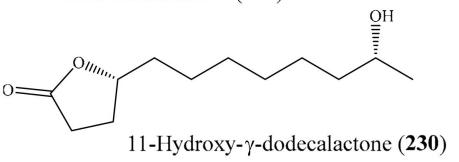<smiles>CSC(=O)c1c(C)cc2c(c1O)CC(C(C)(C)O)O2</smiles>

Eurothiocin A (231)<smiles>CSC(=O)c1c(C)cc2c(c1O)CC(C(C)(C)O)O2</smiles><smiles>CC(=O)C1(Cc2ccc(O)c(CC(C)C(C)C)c2)OC(=O)C=C1c1ccc(O)cc1</smiles>

Aspernolide D (234)

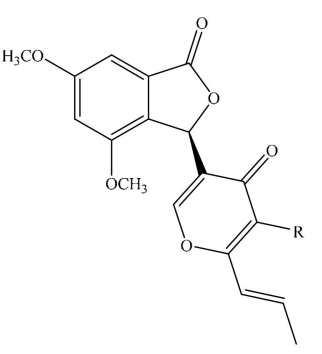

Vermistatin: $\mathrm{R}=\mathrm{H}(\mathbf{2 3 5})$ Methoxyvermistatin: $\mathrm{R}=\mathrm{OCH}_{3}(\mathbf{2 3 6})$

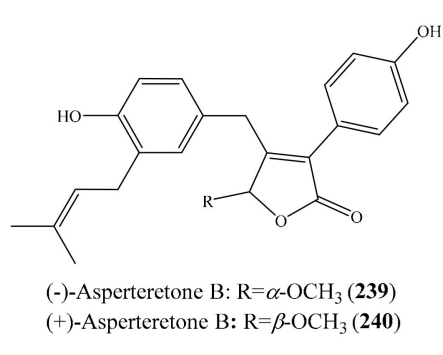

(+)-Asperteretone $\mathrm{B}: \mathrm{R}=\beta-\mathrm{OCH}_{3}(\mathbf{2 4 0})$

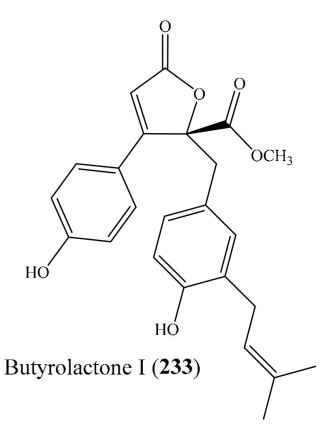

(-)-Asperteretone A: $\mathrm{R}_{1}=\alpha-\mathrm{COOCH}_{3}, \mathrm{R}_{2}=\beta$ - $\mathrm{COOH}$ (237) (+)-Asperteretone $\mathrm{A}: \mathrm{R}_{1}=\beta$ - $\mathrm{COOCH}_{3}, \mathrm{R}_{2}=\alpha$ - $\mathrm{COOH}$ (238)

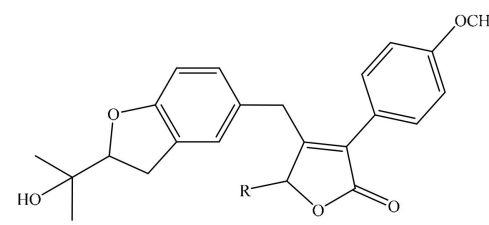

(-)-Asperteretone $\mathrm{C}: \mathrm{R}=\alpha$ - $-\mathrm{OCH}_{3}(\mathbf{2 4 1})$ (+)-Asperteretone $\mathrm{C}: \mathrm{R}=\beta-\mathrm{OCH}_{3}(\mathbf{2 4 2})$

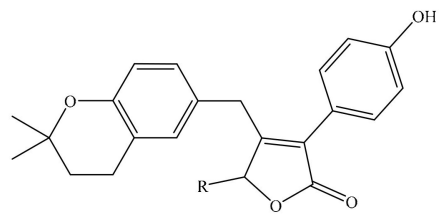

(-)-Asperteretone $\mathrm{D}: \mathrm{R}=\alpha-\mathrm{OCH}_{3}(\mathbf{2 4 3})$ (+)-Asperteretone $\mathrm{D}: \mathrm{R}=\beta-\mathrm{OCH}_{3}(\mathbf{2 4 4})$

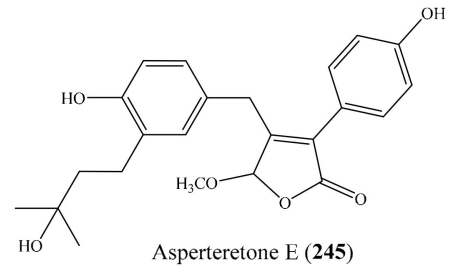

Asperteretone E (245)

Figure 30. Chemical structures of 229-245.

Besides, several $\alpha$-glucosidase inhibitory compounds have been isolated from coral-derived microorganisms. Liu et al. [184] isolated two new sulfur-containing benzofuran derivatives, eurothiocins $\mathrm{A}$ and B, along with five known compounds, from cultures of Eurotium rubrum SH-823, a fungus obtained from soft coral Sarcophyton sp. Notably, six compounds (eurothiocins A (231) and B (232), butyrolactone I (233), aspernolide D (234), vermistatin (235), and methoxyvermistatin (236) (Figure 30)) exhibited more potent inhibitory effects against $\alpha$-glucosidase activity than the clinical $\alpha$-glucosidase inhibitor acarbose $\left(\mathrm{IC}_{50}=376.7 \pm 5.2 \mu \mathrm{M}\right)$. In addition, a mechanistic analysis showed that 231 and 232 exhibited competitive inhibition characteristics [184]. In another study, Liu et al. [185] also isolated nine novel butenolide derivatives, including four pairs of enantiomers, ( \pm )-asperteretones A-D (237-244), and a racemate, asperteretone E (245) (Figure 30), from the fungus Aspergillus terreus, which was isolated from the soft coral Sarcophyton subviride. Interestingly, all of these compounds exhibited potent inhibitory activity against $\alpha$-glucosidase, with $\mathrm{IC}_{50}$ values ranging from $15.7 \pm 1.1$ to $53.1 \pm 1.4 \mu \mathrm{M}$, which was much lower than those of the positive control acarbose $\left(\mathrm{IC}_{50}=154.7 \pm 8.1 \mu \mathrm{M}\right)$, suggesting them as promising leading compounds for the discovery of new $\alpha$-glucosidase inhibitors for type-2 diabetes mellitus treatment. Interestingly, it was observed that all enantiomers displayed nearly similar $\mathrm{IC}_{50}$ values against $\alpha$-glucosidase inhibitory activity, suggesting that the difference of chirality may have a negligible influence on their activity.

\section{Comprehensive Overview and Outlook}

The present review revealed that coral and its associated microorganisms are a prolific source of structurally diverse secondary metabolites with different biological activities (Supplementary Tables S1-S11). Particularly, our review highlighted 245 highly bioactive compounds as a promising source for therapeutic agents. These compounds possess a wide range of bioactivities, such as anti-inflammatory, 
cytotoxic, antimicrobial, antivirus, and anti-fouling activities, among others. Beyond the current in vitro bioassays, further in vivo and preclinical and clinical studies of these bioactive compounds are required to determine their potential therapeutic applications.

In general, there has been a slight decrease in the number of publications and the number of new compounds from coral over the last decade, whereas the number of publications and new compounds from coral-derived microorganisms slightly increased over the same period (Figure 31). Although coral, as well as other marine invertebrate organisms, can produce rich sources of bioactive natural products with a wide range of bioactivities, their pharmaceutical potentials are often challenged by a supply problem [11,186-188]. Marine organisms often produce minute quantities of natural products: therefore, the collection of large amounts of marine organisms for drug discovery and development is not a sustainable strategy. In other words, microorganism-associated hosts (e.g., sponge, coral) may also produce diverse natural products and offer potential for the exploitation of bioactive metabolites [189-192]. Hence, the discovery of novel bioactive natural products for drug development has been gradually shifted to host-associated microbes.
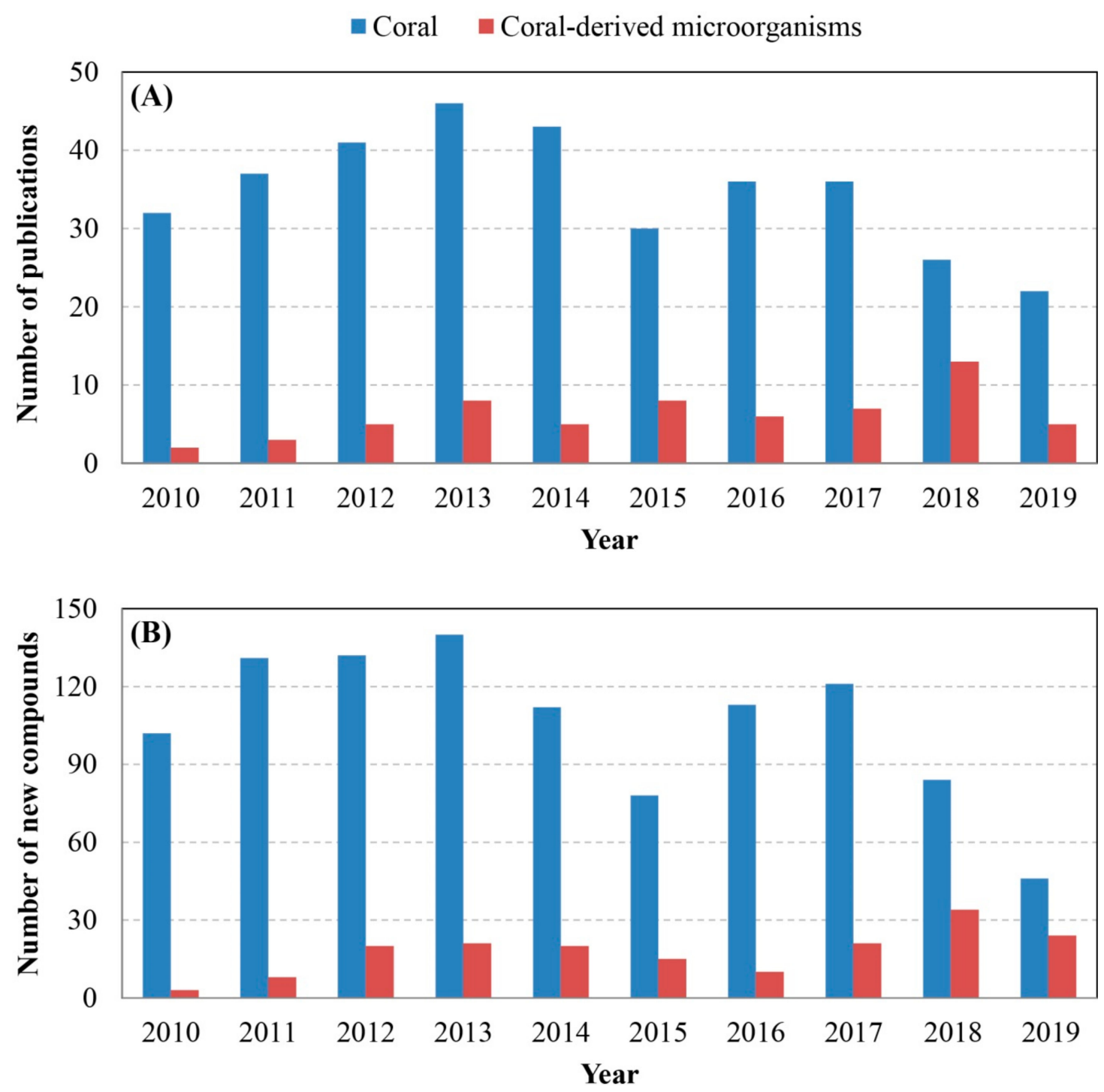

Figure 31. Number of PubMed publications describing natural products from coral and coral-derived microorganisms (A); number of new compounds produced by coral and coral-derived microorganisms (B) covering 2010-March 2019. 
According to structural type, bioactive natural products produced by coral are dominated by terpenoids (59.7\%) and steroids (33.0\%), followed by cyclopentenones, aliphatics, alkaloids, phenolics, quinones, and other compounds (Figure 32A), whereas bioactive compounds produced by coral-derived microorganisms are dominated by three main classes: phenolics $(40.2 \%)$, quinones $(26.1 \%)$, and alkaloids $(20.7 \%)$. Other compounds account for less than 5\% for each (Figure 32B). Based on dominating structure classes, the structure-activity relationship should be analyzed to facilitate the design and synthesis of interesting compounds and their analogues.
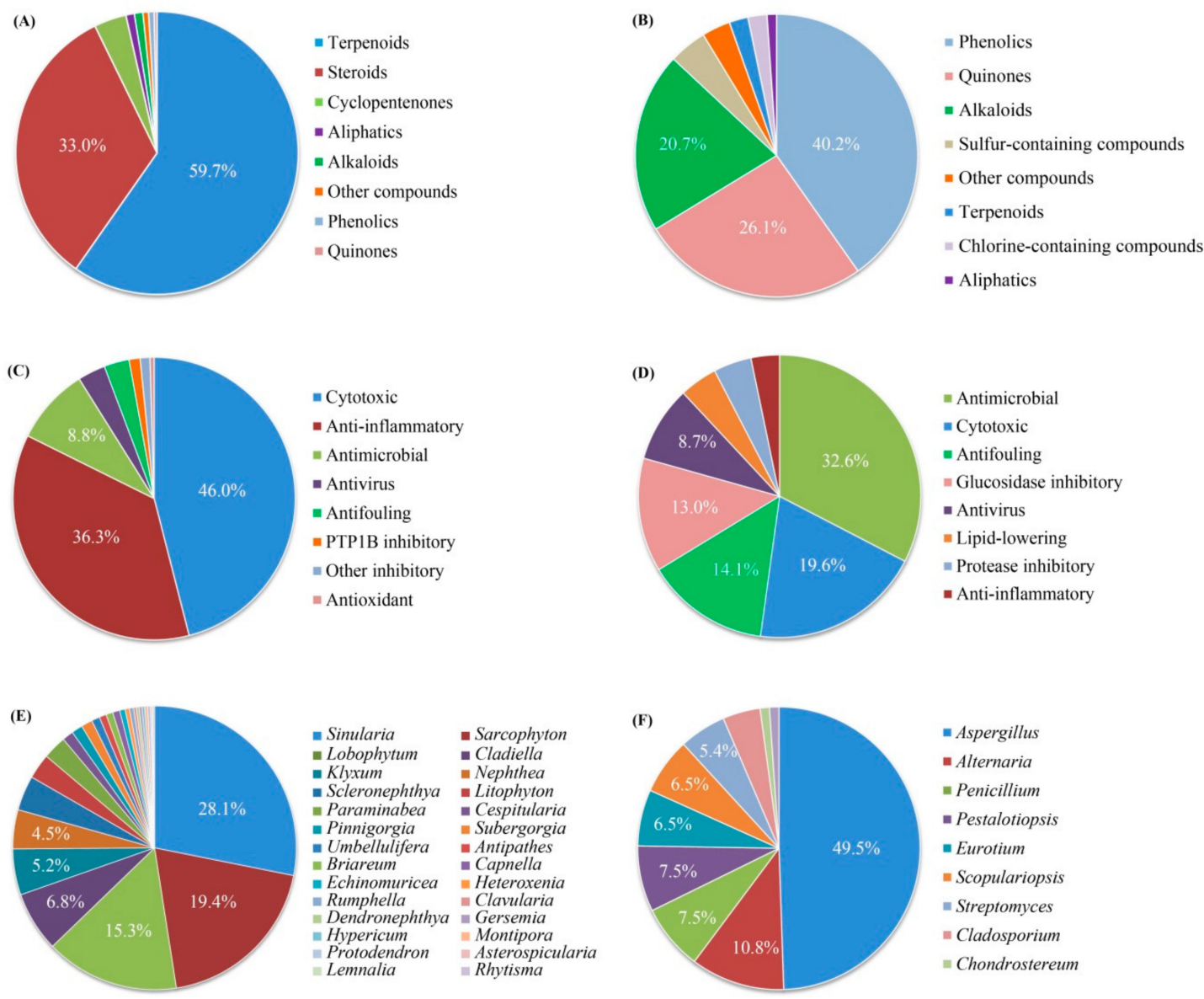

Figure 32. Distribution of the bioactive compounds according to chemical structure for coral (A) and coral-derived microorganisms (B); according to activity type in coral (C) and coral-derived microorganisms (D); according to genera of coral (E) and coral-derived microorganisms (F).

As seen in Figure 32C, the biological activities of compounds from coral are mainly focused in the areas of cytotoxic $(46.0 \%)$, anti-inflammatory $(36.3 \%)$, and antimicrobial activity $(8.8 \%)$; whereas other selective activities, including antivirus, antifouling, antioxidant, PTP1B inhibitory, and other inhibitory activities, account for less than $5 \%$ for each. For coral-associated microorganisms, the bioactivity of compounds is mainly focused in the areas of antimicrobial (32.6\%), cytotoxic (19.6\%), antifouling $(14.1 \%)$, and $\alpha$-glucosidase inhibitory activity (13.0\%). Furthermore, other activities such as antiviral, lipid-lowering, protease inhibitory, and anti-inflammatory activities are found in compounds produced by coral-associated microorganisms (Figure 32D).

It was observed that coral-derived bioactive compounds are found in nearly 30 genera. The majority of coral-derived bioactive compounds are produced by three main genera: Simularia $(28.1 \%)$, Sarcophyton (19.4\%), and Lobophytum (15.3\%) (Figure 32E), suggesting that these genera should be subjected to advanced aquaculture studies in order to obtain enough biomass for further preclinical and clinical trials and commercialization. Several corals (e.g., Sinularia sp., S. gaweli, S. flexilis) have 
begun to be transplanted into culturing tanks with a flow-through seawater system located in the National Museum of Marine Biology and Aquarium, Taiwan, for the extraction of additional natural products in order to establish a stable supply of bioactive material $[107,117,118]$. For coral-associated microorganisms (Figure 32F), fungi and bacteria are two groups that have been found to produce bioactive compounds; however, the large majority of bioactive compounds are produced by fungi (93.5\%), whereas bacteria account for only $6.5 \%$. Particularly, approximately $50 \%$ of bioactive compounds are produced by the genus Aspergillus, implying that Aspergillus is one of the key producers of natural products from coral-derived microorganisms. Further studies on the chemical and biological activities of this genus should be investigated. Specifically, advanced approaches that allow for the activation of the expression and production of novel/cryptic compounds of Aspergillus should be developed.

Although bioactive compounds from coral and its associated microorganisms show interesting levels for a number of clinically relevant targets, they are not well represented in the pipelines of drugs and none of them has been successfully marketed as a pharmaceutical. While the exploitation of bioactive natural products from coral for drug development is still limited by a supply problem and the sustainable conservation of coral reefs [11,186-188], drug discovery from coral-derived microorganisms is more sustainable and can overcome the supply issue through the large-scale fermentation of microorganisms. However, drug development from coral-derived microorganisms has been hampered due to only a minor number of microbes being able to be maintained in laboratory conditions $[24,193,194]$. Furthermore, most of the biosynthetic gene clusters expressing novel bioactive metabolites remain silent or cryptic under laboratory culture conditions [195-197]. Therefore, in order to unravel and exploit novel bioactive compounds from coral for drug development, the development of advanced aquacultures is required to obtain enough biomass for preclinical and clinical trials and commercialization [198-201]. For coral-associated microorganisms, new methods and technologies are warranted to activate the expression of the novel/cryptic secondary metabolome of microbes. In addition, new cultivation methods enhancing the cultivation of novel microbes and providing suitable culture conditions for the activation of silent genes of novel/cryptic biosynthetic gene clusters should be developed (e.g., cocultivation, in situ culture or culture stimulated in natural conditions, and the use of "omics"-based culture media). In particular, with the development of next-generation sequencing technologies, cultivation-independent methods (e.g., genomics, metagenomics, proteomics) should be applied to screen and identify gene clusters involved in the biosynthesis of promising secondary metabolites from yet uncultivable coral-derived microbes. Then, the expression of the biosynthetic gene clusters of interesting metabolites through appropriate heterologous expression systems can be required to produce the metabolites [202]. Combination of "omics"-based approaches and molecular approaches are expected to open up an unexplored reservoir of bioactive natural products from uncultivable coral-derived microbes.

It is noted that the supply problem of natural products from coral and coral-derived microorganisms can also be overcome by synthesis and/or semisynthesis approaches. The present review found that several compounds from coral and coral-derived microorganisms exhibited very strong activity $\left(\mathrm{IC}_{50}<1 \mu \mathrm{M}\right.$ ), stronger activity than the positive controls (e.g., 97-99, 114-117, 179-182, 221), indicating they are potential lead compounds. Therefore, obtaining such compounds and derivatives in sufficient amounts for further studies of their biological properties is of interest. Previous studies have revealed that several potential compounds and their analogues from coral have been synthesized successfully (e.g., acerosolide, bipinnatin J, rubifolide, deoxypukalide, pseudopterosins, fuscosides) [203-209]. However, a number of synthesized metabolites remain modest compared to discovered natural products, and the synthetic yield is low. Despite promising developments, many limitations should be considered in synthesis studies. The complex structural features of natural products often require an enormous number of tedious steps, resulting in low yields and small quantities of the target compounds. Furthermore, due to the large number of tedious steps that are required, the amount of waste products (e.g., toxic solvents, expensive and corrosive reagents) increases. Hence, the 
development and application of advanced synthesis strategies is needed to enhance the efficiency of syntheses of interesting compounds from coral and coral-derived microorganisms.

\section{Conclusions}

This review elucidated the structure and bioactivity of 245 potential compounds from coral and coral-derived microorganisms as promising candidates for further clinical trials. These compounds possess diverse structures and bioactivities. In particular, some compounds have exhibited very strong activity, with $\mathrm{IC}_{50}<1 \mu \mathrm{M}$ and stronger activity than the positive controls, suggesting that these compounds could be used as potential lead compounds in the synthesis of more active analogues and/or new drugs. It is noted that the development of new drugs from coral and coral-derived microorganisms has been hampered by a supply problem. Thus, efforts to introduce and develop new approaches as well as improve current approaches, including synthesis, aquaculture, cultivation, and molecular approaches, are expected to unravel hidden potential natural products of coral and coral-derived microorganisms.

Supplementary Materials: The following are available online at http://www.mdpi.com/1660-3397/17/8/468/s1: Supplementary.docx. Tables S1-S11: Bioactive compounds from coral and its associated microorganisms.

Funding: This research was supported by the Basic Science Research Program through the National Research Foundation of Korea (NRF), funded by the Ministry of Education, Science, and Technology (NRF-2018R1A6A3A11047338).

Conflicts of Interest: The authors declare no conflict of interest.

\section{References}

1. Pietra, F. Biodiversity and Natural Product Diversity, 1st ed.; Pergamon Press: Oxford, UK, 2002; Volume 21.

2. Hay, M.E.; Fenical, W. Chemical ecology and marine biodiversity: Insights and products from the sea. Oceanography 1996, 9, 10-20. [CrossRef]

3. Puglisi, M.P.; Sneed, J.M.; Ritson-Williams, R.; Young, R. Marine chemical ecology in benthic environments. Nat. Prod. Rep. 2019, 36, 410-429. [CrossRef]

4. Rohde, S.; Nietzer, S.; Schupp, P.J. Prevalence and Mechanisms of Dynamic Chemical Defenses in Tropical Sponges. PLoS ONE 2015, 10, e0132236. [CrossRef]

5. Coll, J.C.; Barre, S.L.; Sammarco, P.W.; Williams, W.T.; Bakus, G.J. Chemical Defences in Soft Corals (Coelenterata: Octocorallia) of the Great Barrier Reef: A Study of Comparative Toxicities. Mar. Ecol. Prog. Ser. 1982, 8, 271-278. [CrossRef]

6. McClintock, J.B.; Amsler, C.D.; Baker, B.J. Overview of the Chemical Ecology of Benthic Marine Invertebrates along the Western Antarctic Peninsula. Integr. Comp. Biol. 2010, 50, 967-980. [CrossRef]

7. Lindquist, N. Chemical Defense of Early Life Stages of Benthic Marine Invertebrates. J. Chem. Ecol. 2002, 28, 1987-2000. [CrossRef]

8. Eskander, R.; Al-Sofyani, A.A.; El-Sherbiny, M.M.O.; Ba-Akdah, M.A.; Satheesh, S. Chemical Defense of Soft Coral Sinularia polydactyla from the Red Sea Against Marine Biofilm-Forming Bacteria. J. Ocean Univ. China 2018, 17, 1451-1457. [CrossRef]

9. Marris, E. Drugs from the deep. Nature 2006, 443, 904-905. [CrossRef]

10. Molinski, T.F.; Dalisay, D.S.; Lievens, S.L.; Saludes, J.P. Drug development from marine natural products. Nat. Rev. Drug Discov. 2008, 8, 69-85. [CrossRef]

11. Lindequist, U. Marine-Derived Pharmaceuticals-Challenges and Opportunities. Biomol. Ther. 2016, 24, 561-571. [CrossRef]

12. Malve, H. Exploring the ocean for new drug developments: Marine pharmacology. J. Pharm. Bioallied Sci. 2016, 8, 83-91. [CrossRef]

13. De Zoysa, M. Chapter 9-Medicinal Benefits of Marine Invertebrates: Sources for Discovering Natural Drug Candidates. Adv. Food Nutr. Res. 2012, 65, 153-169.

14. Hu, G.-P.; Yuan, J.; Sun, L.; She, Z.-G.; Wu, J.-H.; Lan, X.-J.; Zhu, X.; Lin, Y.-C.; Chen, S.-P. Statistical research on marine natural products based on data obtained between 1985 and 2008. Mar. Drugs 2011, 9, 514-525. [CrossRef] 
15. Horta, A.; Alves, C.; Pinteus, S.; Pedrosa, R. The marine origin of drugs. In Phycotoxins, 2nd ed.; John Wiley \& Sons: London, UK, 2015.

16. Simmons, T.L.; Andrianasolo, E.; McPhail, K.; Flatt, P.; Gerwick, W.H. Marine natural products as anticancer drugs. Mol. Cancer Ther. 2005, 4, 333-342.

17. Blunt, J.W.; Copp, B.R.; Keyzers, R.A.; Munro, M.H.G.; Prinsep, M.R. Marine natural products. Nat. Prod. Rep. 2013, 30, 237-323. [CrossRef]

18. Blunt, J.W.; Copp, B.R.; Keyzers, R.A.; Munro, M.H.G.; Prinsep, M.R. Marine natural products. Nat. Prod. Rep. 2012, 29, 144-222. [CrossRef]

19. Blunt, J.W.; Copp, B.R.; Munro, M.H.G.; Northcote, P.T.; Prinsep, M.R. Marine natural products. Nat. Prod. Rep. 2011, 28, 196-268. [CrossRef]

20. Wu, Q.; Sun, J.; Chen, J.; Zhang, H.; Guo, Y.-W.; Wang, H. Terpenoids from Marine Soft Coral of the Genus Lemnalia: Chemistry and Biological Activities. Mar. Drugs 2018, 16, 320. [CrossRef]

21. Rodrigues, G.I.; Miguel, G.M.; Mnif, W. A Brief Review on New Naturally Occurring Cembranoid Diterpene Derivatives from the Soft Corals of the Genera Sarcophyton, Sinularia, and Lobophytum Since 2016. Molecules 2019, 24, 781. [CrossRef]

22. Mayer, A.M.S.; Rodríguez, A.D.; Berlinck, R.G.S.; Fusetani, N. Marine pharmacology in 2007-8: Marine compounds with antibacterial, anticoagulant, antifungal, anti-inflammatory, antimalarial, antiprotozoal, antituberculosis, and antiviral activities; affecting the immune and nervous system, and other miscellaneous mechanisms of action. Comp. Biochem. Physiol. C Toxicol. Pharmacol. 2011, 153, 191-222.

23. Kooperman, N.; Ben-Dov, E.; Kramarsky-Winter, E.; Barak, Z.; Kushmaro, A. Coral mucus-associated bacterial communities from natural and aquarium environments. FEMS Microbiol. Lett. 2007, 276, 106-113. [CrossRef]

24. Rohwer, F.; Breitbart, M.; Jara, J.; Azam, F.; Knowlton, N. Diversity of bacteria associated with the Caribbean coral Montastraea franksi. Coral Reefs 2001, 20, 85-91.

25. Pollock, F.J.; McMinds, R.; Smith, S.; Bourne, D.G.; Willis, B.L.; Medina, M.; Thurber, R.V.; Zaneveld, J.R. Coral-associated bacteria demonstrate phylosymbiosis and cophylogeny. Nat. Commun. 2018, 9, 4921. [CrossRef]

26. Huggett, M.J.; Apprill, A. Coral microbiome database: Integration of sequences reveals high diversity and relatedness of coral-associated microbes. Environ. Microbiol. Rep. 2019, 11, 372-385. [CrossRef]

27. Mahmoud, H.M.; Kalendar, A.A. Coral-associated actinobacteria: Diversity, abundance, and biotechnological potentials. Front. Microbiol. 2016, 7, 204. [CrossRef]

28. Lawler, S.N.; Kellogg, C.A.; France, S.C.; Clostio, R.W.; Brooke, S.D.; Ross, S.W. Coral-Associated Bacterial Diversity Is Conserved across Two Deep-Sea Anthothela Species. Front. Microbiol. 2016, 7, 458. [CrossRef]

29. La Rivière, M.; Garrabou, J.; Bally, M. Evidence for host specificity among dominant bacterial symbionts in temperate gorgonian corals. Coral Reefs 2015, 34, 1087-1098. [CrossRef]

30. van de Water, J.A.J.M.; Melkonian, R.; Voolstra, C.R.; Junca, H.; Beraud, E.; Allemand, D.; Ferrier-Pagès, C. Comparative Assessment of Mediterranean Gorgonian-Associated Microbial Communities Reveals Conserved Core and Locally Variant Bacteria. Microb. Ecol. 2017, 73, 466-478. [CrossRef]

31. Rosenberg, E.; Koren, O.; Reshef, L.; Efrony, R.; Zilber-Rosenberg, I. The role of microorganisms in coral health, disease and evolution. Nat. Rev. Microbiol. 2007, 5, 355-362. [CrossRef]

32. Zaneveld, J.R.; Burkepile, D.E.; Shantz, A.A.; Pritchard,C.E.; McMinds, R.; Payet, J.P.; Welsh, R.; Correa, A.M.S.; Lemoine, N.P.; Rosales, S.; et al. Overfishing and nutrient pollution interact with temperature to disrupt coral reefs down to microbial scales. Nat. Commun. 2016, 7, 11833. [CrossRef]

33. Sunagawa, S.; DeSantis, T.Z.; Piceno, Y.M.; Brodie, E.L.; DeSalvo, M.K.; Voolstra, C.R.; Weil, E.; Andersen, G.L.; Medina, M. Bacterial diversity and White Plague Disease-associated community changes in the Caribbean coral Montastraea faveolata. ISME J. 2009, 3, 512-521. [CrossRef]

34. Sato, Y.; Willis, B.L.; Bourne, D.G. Successional changes in bacterial communities during the development of black band disease on the reef coral, Montipora hispida. ISME J. 2009, 4, 203-214. [CrossRef]

35. Morrow, K.M.; Muller, E.; Lesser, M.P. How Does the Coral Microbiome Cause, Respond to, or Modulate the Bleaching Process? In Coral Bleaching: Patterns, Processes, Causes and Consequences; van Oppen, M.J.H., Lough, J.M., Eds.; Springer International Publishing: Cham, Switzerland, 2018; pp. 153-188.

36. Roitman, S.; Joseph Pollock, F.; Medina, M. Coral Microbiomes as Bioindicators of Reef Health. In Population Genomics; Springer: Cham, Switzerland, 2018. 
37. Alagely, A.; Krediet, C.J.; Ritchie, K.B.; Teplitski, M. Signaling-mediated cross-talk modulates swarming and biofilm formation in a coral pathogen Serratia marcescens. ISME J. 2011, 5, 1609-1620. [CrossRef]

38. Kim, B.R. Regulation of microbial populations by coral surface mucus and mucus-associated bacteria. Mar. Ecol. Prog. Ser. 2006, 322, 1-14.

39. Teplitski, M.; Ritchie, K. How feasible is the biological control of coral diseases? Trends Ecol. Evol. 2009, 24, 378-385. [CrossRef]

40. Shnit-Orland, M.; Kushmaro, A. Coral mucus-associated bacteria: A possible first line of defense. FEMS Microbiol. Ecol. 2009, 67, 371-380. [CrossRef]

41. Debbab, A.; Aly, A.H.; Lin, W.H.; Proksch, P. Bioactive Compounds from Marine Bacteria and Fungi. Microb. Biotechnol. 2010, 3, 544-563. [CrossRef]

42. Lei, H. Diterpenoids of Gorgonian Corals: Chemistry and Bioactivity. Chem. Biodivers. 2016, 13, $345-365$. [CrossRef]

43. Su, Y.-D.; Su, J.-H.; Hwang, T.-L.; Wen, Z.-H.; Sheu, J.-H.; Wu, Y.-C.; Sung, P.-J. Briarane Diterpenoids Isolated from Octocorals between 2014 and 2016. Mar. Drugs 2017, 15, 44. [CrossRef]

44. Sheu, J.-H.; Chen, Y.-H.; Chen, Y.-H.; Su, Y.-D.; Chang, Y.-C.; Su, J.-H.; Weng, C.-F.; Lee, C.-H.; Fang, L.-S.; Wang, W.-H.; et al. Briarane diterpenoids isolated from gorgonian corals between 2011 and 2013. Mar. Drugs 2014, 12, 2164-2181. [CrossRef]

45. Chang, Y.-C.; Sheu, J.-H.; Wu, Y.-C.; Sung, P.-J. Terpenoids from Octocorals of the Genus Pachyclavularia. Mar. Drugs 2017, 15, 382. [CrossRef]

46. Carroll, A.R.; Copp, B.R.; Davis, R.A.; Keyzers, R.A.; Prinsep, M.R. Marine natural products. Nat. Prod. Rep. 2019, 36, 122-173. [CrossRef]

47. Scrivo, R.; Vasile, M.; Bartosiewicz, I.; Valesini, G. Inflammation as "common soil" of the multifactorial diseases. Autoimmun. Rev. 2011, 10, 369-374. [CrossRef]

48. Sostres, C.; Gargallo, C.J.; Arroyo, M.T.; Lanas, A. Adverse effects of non-steroidal anti-inflammatory drugs (NSAIDs, aspirin and coxibs) on upper gastrointestinal tract. Best Pract. Res. Clin. Gastroenterol. 2010, 24, 121-132. [CrossRef]

49. Yan, P.; Lv, Y.; van Ofwegen, L.; Proksch, P.; Lin, W. Lobophytones A-G, new isobiscembranoids from the soft coral Lobophytum pauciflorum. Org. Lett. 2010, 12, 2484-2487. [CrossRef]

50. Chen, B.W.; Chang, S.M.; Huang, C.Y.; Chao, C.H.; Su, J.H.; Wen, Z.H.; Hsu, C.H.; Dai, C.F.; Wu, Y.C.; Sheu, J.H. Hirsutalins A-H, eunicellin-based diterpenoids from the soft coral Cladiella hirsuta. J. Nat. Prod. 2010, 73, 1785-1791. [CrossRef]

51. Quang, T.H.; Ha, T.T.; Minh, C.V.; Kiem, P.V.; Huong, H.T.; Ngan, N.T.; Nhiem, N.X.; Tung, N.H.; Tai, B.H.; Thuy, D.T.; et al. Cytotoxic and anti-inflammatory cembranoids from the Vietnamese soft coral Lobophytum laevigatum. Bioorg. Med. Chem. 2011, 19, 2625-2632. [CrossRef]

52. Su, J.H.; Wen, Z.H. Bioactive cembrane-based diterpenoids from the soft coral Sinularia Triangular. Mar. Drugs 2011, 9, 944-951. [CrossRef]

53. Kao, C.Y.; Su, J.H.; Lu, M.C.; Hwang, T.L.; Wang, W.H.; Chen, J.J.; Sheu, J.H.; Kuo, Y.H.; Weng, C.F.; Fang, L.S.; et al. Lobocrassins A-E: New cembrane-type diterpenoids from the soft coral Lobophytum crassum. Mar. Drugs 2011, 9, 1319-1331. [CrossRef]

54. Chao, C.H.; Chou, K.J.; Wen, Z.H.; Wang, G.H.; Wu, Y.C.; Dai, C.F.; Sheu, J.H. Paraminabeolides A-F, cytotoxic and anti-inflammatory marine withanolides from the soft coral Paraminabea acronocephala. J. Nat. Prod. 2011, 74, 1132-1141. [CrossRef]

55. Hsu, F.-J.; Chen, B.-W.; Wen, Z.-H.; Huang, C.-Y.; Dai, C.-F.; Su, J.-H.; Wu, Y.-C.; Sheu, J.-H. Klymollins A-H, bioactive eunicellin-based diterpenoids from the Formosan soft coral Klyxum molle. J. Nat. Prod. 2011, 74, 2467-2471. [CrossRef]

56. Lin, W.Y.; Lu, Y.; Su, J.H.; Wen, Z.H.; Dai, C.F.; Kuo, Y.H.; Sheu, J.H. Bioactive cembranoids from the dongsha atoll soft coral Sarcophyton crassocaule. Mar. Drugs 2011, 9, 994-1006. [CrossRef]

57. Chung, H.M.; Hong, P.H.; Su, J.H.; Hwang, T.L.; Lu, M.C.; Fang, L.S.; Wu, Y.C.; Li, J.J.; Chen, J.J.; Wang, W.H.; et al. Bioactive compounds from a gorgonian coral Echinomuricea sp. (Plexauridae). Mar. Drugs 2012, 10, 1169-1179. [CrossRef]

58. Lin, W.Y.; Lu, Y.; Chen, B.W.; Huang, C.Y.; Su, J.H.; Wen, Z.H.; Dai, C.F.; Kuo, Y.H.; Sheu, J.H. Sarcocrassocolides M-O, bioactive cembranoids from the Dongsha Atoll soft coral Sarcophyton crassocaule. Mar. Drugs 2012, 10, 617-626. [CrossRef] 
59. Fang, H.-Y.; Liaw, C.-C.; Chao, C.-H.; Wen, Z.-H.; Wu, Y.-C.; Hsu, C.-H.; Dai, C.-F.; Sheu, J.-H. Bioactive pregnane-type steroids from the soft coral Scleronephthya gracillimum. Tetrahedron 2012, 68, 9694-9700. [CrossRef]

60. Chen, Y.-H.; Hwang, T.-L.; Su, Y.-D.; Chang, Y.-C.; Chen, Y.-H.; Hong, P.-H.; Hu, L.-C.; Yen, W.-H.; Hsu, H.-Y.; Huang, S.-J. New 6-hydroxyeunicellins from a soft coral Cladiella sp. Chem. Pharm. Bull. 2012, 60, 160-163. [CrossRef]

61. Yang, B.; Zhou, X.; Huang, H.; Yang, X.-W.; Liu, J.; Lin, X.; Li, X.; Peng, Y.; Liu, Y. New cembrane diterpenoids from a Hainan soft coral Sinularia sp. Mar. Drugs 2012, 10, 2023-2032. [CrossRef]

62. Tai, C.J.; Su, J.H.; Huang, C.Y.; Huang, M.S.; Wen, Z.H.; Dai, C.F.; Sheu, J.H. Cytotoxic and anti-inflammatory eunicellin-based diterpenoids from the soft coral Cladiella krempfi. Mar. Drugs 2013, 11, 788-799. [CrossRef]

63. Thao, N.P.; Nam, N.H.; Cuong, N.X.; Quang, T.H.; Tung, P.T.; Dat Le, D.; Chae, D.; Kim, S.; Koh, Y.S.; Kiem, P.V.; et al. Anti-inflammatory norditerpenoids from the soft coral Sinularia maxima. Bioorg. Med. Chem. Lett. 2013, 23, 228-231. [CrossRef]

64. Nguyen, P.T.; Nguyen, H.N.; Nguyen, X.C.; Nguyen, X.N.; Pham, T.T.; Tran, H.Q.; Nguyen, T.T.N.; Phan, V.K.; Chau, V.M.; Kim, Y.H. A new sterol from the soft coral Lobophytum crassum. Bull. Korean Chem. Soc. 2013, 34, 249-251. [CrossRef]

65. Yin, J.; Zhao, M.; Ma, M.; Xu, Y.; Xiang, Z.; Cai, Y.; Dong, J.; Lei, X.; Huang, K.; Yan, P. New casbane diterpenoids from a South China Sea soft coral, Sinularia sp. Mar. Drugs 2013, 11, 455-465. [CrossRef]

66. Lin, M.C.; Chen, B.W.; Huang, C.Y.; Dai, C.F.; Hwang, T.L.; Sheu, J.H. Eunicellin-based diterpenoids from the Formosan soft coral Klyxum molle with inhibitory activity on superoxide generation and elastase release by neutrophils. J. Nat. Prod. 2013, 76, 1661-1667. [CrossRef]

67. Chen, B.-W.; Wang, S.-Y.; Huang, C.-Y.; Chen, S.-L.; Wu, Y.-C.; Sheu, J.-H. Hirsutalins I-M, eunicellin-based diterpenoids from the soft coral Cladiella hirsuta. Tetrahedron 2013, 69, 2296-2301. [CrossRef]

68. Thao, N.P.; Luyen, B.T.; Ngan, N.T.; Song, S.B.; Cuong, N.X.; Nam, N.H.; Kiem, P.V.; Kim, Y.H.; Minh, C.V. New anti-inflammatory cembranoid diterpenoids from the Vietnamese soft coral Lobophytum crassum. Bioorg. Med. Chem. Lett. 2014, 24, 228-232. [CrossRef]

69. Cuong, N.X.; Thao, N.P.; Luyen, B.T.T.; Ngan, N.T.T.; Thuy, D.T.T.; Song, S.B.; Nam, N.H.; Van Kiem, P.; Kim, Y.H.; Van Minh, C. Cembranoid diterpenes from the soft coral Lobophytum crassum and their anti-inflammatory activities. Chem. Pharm. Bull. 2014, 62, 203-208. [CrossRef]

70. Thao, N.P.; Luyen, B.T.; Sun, Y.N.; Song, S.B.; Thanh, N.V.; Cuong, N.X.; Nam, N.H.; Kiem, P.V.; Kim, Y.H.; Minh, C.V. NF-kappaB inhibitory activity of polyoxygenated steroids from the Vietnamese soft coral Sarcophyton pauciplicatum. Bioorg. Med. Chem. Lett. 2014, 24, 2834-2838. [CrossRef]

71. Lee, Y.N.; Tai, C.J.; Hwang, T.L.; Sheu, J.H. Krempfielins N-P, new anti-inflammatory eunicellins from a Taiwanese soft coral Cladiella krempfi. Mar. Drugs 2014, 12, 1148-1156. [CrossRef]

72. Lin, W.Y.; Chen, B.W.; Huang, C.Y.; Wen, Z.H.; Sung, P.J.; Su, J.H.; Dai, C.F.; Sheu, J.H. Bioactive cembranoids, sarcocrassocolides P-R, from the Dongsha Atoll soft coral Sarcophyton crassocaule. Mar. Drugs 2014, 12, 840-850. [CrossRef]

73. Chao, C.-H.; Huang, T.-Z.; Wu, C.-Y.; Chen, B.-W.; Huang, C.-Y.; Hwang, T.-L.; Dai, C.-F.; Sheu, J.-H. Steroidal and $\alpha$-tocopherylhydroquinone glycosides from two soft corals Cladiella hirsuta and Sinularia nanolobata. RSC Adv. 2015, 5, 74256-74262. [CrossRef]

74. Huang, C.Y.; Tseng, Y.J.; Chokkalingam, U.; Hwang, T.L.; Hsu, C.H.; Dai, C.F.; Sung, P.J.; Sheu, J.H. Bioactive isoprenoid-derived natural products from a Dongsha Atoll soft coral Sinularia erecta. J. Nat. Prod. 2016, 79, 1339-1346. [CrossRef]

75. Tsai, C.-R.; Huang, C.-Y.; Chen, B.-W.; Tsai, Y.-Y.; Shih, S.-P.; Hwang, T.-L.; Dai, C.-F.; Wang, S.-Y.; Sheu, J.-H. New bioactive steroids from the soft coral Klyxum flaccidum. RSC Adv. 2015, 5, 12546-12554. [CrossRef]

76. Huang, C.Y.; Sung, P.J.; Uvarani, C.; Su, J.H.; Lu, M.C.; Hwang, T.L.; Dai, C.F.; Wu, S.L.; Sheu, J.H. Glaucumolides A and B, biscembranoids with new structural type from a cultured soft coral Sarcophyton glaucum. Sci. Rep. 2015, 5, 15624. [CrossRef]

77. Tsai, Y.Y.; Huang, C.Y.; Tseng, W.R.; Chiang, P.L.; Hwang, T.L.; Su, J.H.; Sung, P.J.; Dai, C.F.; Sheu, J.H. Klyflaccisteroids K-M, bioactive steroidal derivatives from a soft coral Klyxum flaccidum. Bioorg. Med. Chem. Lett. 2017, 27, 1220-1224. [CrossRef]

78. Chang, Y.C.; Kuo, L.M.; Hwang, T.L.; Yeh, J.; Wen, J.H.; Fang, L.S.; Wu, Y.C.; Lin, C.S.; Sheu, J.H.; Sung, P.J. Pinnisterols A-C, new 9,11-secosterols from a Gorgonian Pinnigorgia sp. Mar. Drugs 2016, 14, 12. [CrossRef] 
79. Huang, C.Y.; Chang, C.W.; Tseng, Y.J.; Lee, J.; Sung, P.J.; Su, J.H.; Hwang, T.L.; Dai, C.F.; Wang, H.C.; Sheu, J.H. Bioactive steroids from the Formosan soft coral Umbellulifera petasites. Mar. Drugs 2016, 14, 180. [CrossRef]

80. Tseng, W.R.; Huang, C.Y.; Tsai, Y.Y.; Lin, Y.S.; Hwang, T.L.; Su, J.H.; Sung, P.J.; Dai, C.F.; Sheu, J.H. New cytotoxic and anti-inflammatory steroids from the soft coral Klyxum flaccidum. Bioorg. Med. Chem. Lett. 2016, 26, 3253-3257. [CrossRef]

81. Zhao, M.; Cheng, S.; Yuan, W.; Xi, Y.; Li, X.; Dong, J.; Huang, K.; Gustafson, K.R.; Yan, P. Cembranoids from a Chinese collection of the soft coral Lobophytum crassum. Mar. Drugs 2016, 14, 111. [CrossRef]

82. Chang, Y.-C.; Kuo, L.-M.; Su, J.-H.; Hwang, T.-L.; Kuo, Y.-H.; Lin, C.-S.; Wu, Y.-C.; Sheu, J.-H.; Sung, P.-J. Pinnigorgiols A-C, 9,11-secosterols with a rare ring arrangement from a gorgonian coral Pinnigorgia sp. Tetrahedron 2016, 72, 999-1004. [CrossRef]

83. Huang, C.Y.; Ahmed, A.F.; Su, J.H.; Sung, P.J.; Hwang, T.L.; Chiang, P.L.; Dai, C.F.; Liaw, C.C.; Sheu, J.H. Bioactive new withanolides from the cultured soft coral Sinularia brassica. Bioorg. Med. Chem. Lett. 2017, 27, 3267-3271. [CrossRef]

84. Wu, Q.; Li, X.W.; Li, H.; Yao, L.G.; Tang, W.; Miao, Z.H.; Wang, H.; Guo, Y.W. Bioactive polyoxygenated cembranoids from a novel Hainan chemotype of the soft coral Sinularia flexibilis. Bioorg. Med. Chem. Lett. 2019, 29, 185-188. [CrossRef]

85. Andrea, N.; Angelo, C.; Paola, F.; Pier Mario, B.; Giuseppe, R. Immunotherapy and Hormone-therapy in Metastatic Breast Cancer: A Review and an Update. Curr. Drug Targets 2016, 17, 1127-1139.

86. Mullard, A. FDA approves first immunotherapy combo. Nat. Rev. Drug Discov. 2015, 14, 739. [CrossRef]

87. Ali, R.; Mirza, Z.; Ashraf, G.M.D.; Kamal, M.A.; Ansari, S.A.; Damanhouri, G.A.; Abuzenadah, A.M.; Chaudhary, A.G.; Sheikh, I.A. New Anticancer Agents: Recent Developments in Tumor Therapy. Anticancer Res. 2012, 32, 2999-3005.

88. Khoo, B.L.; Chaudhuri, P.K.; Ramalingam, N.; Tan, D.S.W.; Lim, C.T.; Warkiani, M.E. Single-cell profiling approaches to probing tumor heterogeneity. Int. J. Cancer 2016, 139, 243-255. [CrossRef]

89. Feinberg, A.P.; Ohlsson, R.; Henikoff, S. The epigenetic progenitor origin of human cancer. Nat. Rev. Genet. 2006, 7, 21-33. [CrossRef]

90. Nguyen, H.T.; Chau, V.M.; Phan, V.K.; Hoang, T.H.; Nguyen, H.N.; Nguyen, X.C.; Tran, H.Q.; Nguyen, X.N.; Hyun, J.H.; Kang, H.K.; et al. Chemical components from the Vietnamese soft coral Lobophytum sp. Arch. Pharm. Res. 2010, 33, 503-508.

91. Chau, V.M.; Phan, V.K.; Nguyen, X.; Nguyen, X.C.; Nguyen, P.T.; Nguyen, H.N.; Hoang Le, T.A.; Do, C.T.; Thuy, D.T.; Kang, H.K.; et al. Cytotoxic and antioxidant activities of diterpenes and sterols from the Vietnamese soft coral Lobophytum compactum. Bioorg. Med. Chem. Lett. 2011, 21, 2155-2159.

92. Tai, C.J.; Su, J.H.; Huang, M.S.; Wen, Z.H.; Dai, C.F.; Sheu, J.H. Bioactive eunicellin-based diterpenoids from the soft coral Cladiella krempfi. Mar. Drugs 2011, 9, 2036-2045. [CrossRef]

93. Hegazy, M.-E.F.; El-Beih, A.A.; Moustafa, A.Y.; Hamdy, A.A.; Alhammady, M.A.; Selim, R.M.; Abdel-Rehim, M.; Paré, P.W. Cytotoxic Cembranoids from the Red Sea Soft Coral Sarcophyton glaucum. Nat. Prod. Commun. 2011, 6, 209-222. [CrossRef]

94. Liao, X.-J.; Tang, L.-D.; Liang, Y.-W.; Geng, H.-W.; Xu, S.-H. Isolation and identification of two new polyhydroxylated sterols from soft coral Sinularia sp. Chem. Res. Chin. Univ. 2011, 27, 217-220.

95. Lee, N.L.; Su, J.H. Tetrahydrofuran cembranoids from the cultured soft coral Lobophytum crassum. Mar. Drugs 2011, 9, 2526-2536. [CrossRef]

96. Cheng, S.Y.; Huang, K.J.; Wang, S.K.; Duh, C.Y. Capilloquinol: A novel farnesyl quinol from the Dongsha atoll soft coral Sinularia capillosa. Mar. Drugs 2011, 9, 469-476. [CrossRef]

97. Lin, Y.S.; Eid Fazary, A.; Chen, C.H.; Kuo, Y.H.; Shen, Y.C. Bioactive xenicane diterpenoids from the Taiwanese soft coral Asterospicularia laurae. Chem. Biodivers. 2011, 8, 1310-1317. [CrossRef]

98. Huang, C.Y.; Su, J.H.; Duh, C.Y.; Chen, B.W.; Wen, Z.H.; Kuo, Y.H.; Sheu, J.H. A new 9,11-secosterol from the soft coral Sinularia granosa. Bioorg. Med. Chem. Lett. 2012, 22, 4373-4376. [CrossRef]

99. Su, J.H.; Huang, C.Y.; Li, P.J.; Lu, Y.; Wen, Z.H.; Kao, Y.H.; Sheu, J.H. Bioactive cadinane-type compounds from the soft coral Sinularia scabra. Arch. Pharm. Res. 2012, 35, 779-784. [CrossRef]

100. Hegazy, M.E.; Gamal Eldeen, A.M.; Shahat, A.A.; Abdel-Latif, F.F.; Mohamed, T.A.; Whittlesey, B.R.; Pare, P.W. Bioactive hydroperoxyl cembranoids from the Red Sea soft coral Sarcophyton glaucum. Mar. Drugs 2012, 10, 209-222. [CrossRef] 
101. Roy, P.K.; Maarisit, W.; Roy, M.C.; Taira, J.; Ueda, K. Five new diterpenoids from an Okinawan soft coral, Cespitularia sp. Mar. Drugs 2012, 10, 2741-2748. [CrossRef]

102. Li, R.; Shao, C.L.; Qi, X.; Li, X.B.; Li, J.; Sun, L.L.; Wang, C.Y. Polyoxygenated sterols from the South China Sea soft coral Sinularia sp. Mar. Drugs 2012, 10, 1422-1432. [CrossRef]

103. Wang, S.K.; Duh, C.Y. New cytotoxic cembranolides from the soft coral Lobophytum michaelae. Mar. Drugs 2012, 10, 306-318. [CrossRef]

104. Wang, S.K.; Hsieh, M.K.; Duh, C.Y. Three new cembranoids from the Taiwanese soft coral Sarcophyton ehrenbergi. Mar. Drugs 2012, 10, 1433-1444. [CrossRef]

105. Wang, S.K.; Puu, S.Y.; Duh, C.Y. New 19-oxygenated steroids from the soft coral Nephthea chabrolii. Mar. Drugs 2012, 10, 1288-1296. [CrossRef]

106. Govindam, S.V.; Yoshioka, Y.; Kanamoto, A.; Fujiwara, T.; Okamoto, T.; Ojika, M. Cyclolobatriene, a novel prenylated germacrene diterpene, from the soft coral Lobophytum pauciflorum. Bioorg. Med. Chem. 2012, 20, 687-692. [CrossRef]

107. Yen, W.H.; Hu, L.C.; Su, J.H.; Lu, M.C.; Twan, W.H.; Yang, S.Y.; Kuo, Y.C.; Weng, C.F.; Lee, C.H.; Kuo, Y.H.; et al. Norcembranoidal diterpenes from a Formosan soft coral Sinularia sp. Molecules 2012, 17, 14058-14066. [CrossRef]

108. Murni, A.; Hanif, N.; Tanaka, J. A new cytotoxic dolabellane from the Indonesian soft coral Anthelia sp. Indones. J. Chem. 2013, 13, 216-220. [CrossRef]

109. Chao, C.H.; Wu, Y.C.; Wen, Z.H.; Sheu, J.H. Steroidal carboxylic acids from soft coral Paraminabea acronocephala. Mar. Drugs 2013, 11, 136-145. [CrossRef]

110. Su, C.C.; Wong, B.S.; Chin, C.; Wu, Y.J.; Su, J.H. Oxygenated cembranoids from the soft coral Sinularia flexibilis. Int. J. Mol. Sci. 2013, 14, 4317-4325. [CrossRef]

111. Huang, C.Y.; Liaw, C.C.; Chen, B.W.; Chen, P.C.; Su, J.H.; Sung, P.J.; Dai, C.F.; Chiang, M.Y.; Sheu, J.H. Withanolide-based steroids from the cultured soft coral Sinularia brassica. J. Nat. Prod. 2013, 76, 1902-1908. [CrossRef]

112. Aboutabl, S.A.; Azzam, S.M.; Michel, C.G.; Selim, N.M.; Hegazy, M.F.; Ali, A.H.; Hussein, A.A. Bioactive terpenoids from the Red Sea soft coral Sinularia polydactyla. Nat. Prod. Res. 2013, 27, 2224-2226. [CrossRef]

113. Zhang, J.; Liao, X.J.; Wang, K.L.; Deng, Z.; Xu, S.H. Cytotoxic cholesta-1,4-dien-3-one derivatives from soft coral Nephthea sp. Steroids 2013, 78, 396-400. [CrossRef]

114. Gong, K.K.; Tang, X.L.; Zhang, G.; Cheng, C.L.; Zhang, X.W.; Li, P.L.; Li, G.Q. Polyhydroxylated steroids from the South China Sea soft coral Sarcophyton sp. and their cytotoxic and antiviral activities. Mar. Drugs 2013, 11, 4788-4798. [CrossRef]

115. Zhao, M.; Yin, J.; Jiang, W.; Ma, M.; Lei, X.; Xiang, Z.; Dong, J.; Huang, K.; Yan, P. Cytotoxic and antibacterial cembranoids from a South China Sea soft coral, Lobophytum sp. Mar. Drugs 2013, 11, 1162-1172. [CrossRef]

116. Ellithey, M.S.; Lall, N.; Hussein, A.A.; Meyer, D. Cytotoxic, cytostatic and HIV-1 PR inhibitory activities of the soft coral Litophyton arboreum. Mar. Drugs 2013, 11, 4917-4936. [CrossRef]

117. Yen, W.H.; Chen, W.F.; Cheng, C.H.; Dai, C.F.; Lu, M.C.; Su, J.H.; Su, Y.D.; Chen, Y.H.; Chang, Y.C.; Chen, Y.H.; et al. A new 5 $5,8 \alpha$-epidioxysterol from the soft coral Sinularia gaweli. Molecules 2013, 18, 2895-2903. [CrossRef]

118. Kuo, C.Y.; Juan, Y.S.; Lu, M.C.; Chiang, M.Y.; Dai, C.F.; Wu, Y.C.; Sung, P.J. Pregnane-type steroids from the Formosan soft coral Scleronephthya flexilis. Int. J. Mol. Sci. 2014, 15, 10136-10149. [CrossRef]

119. Elkhayat, E.S.; Ibrahim, S.R.M.; Fouad, M.A.; Mohamed, G.A. Dendronephthols A-C, new sesquiterpenoids from the Red Sea soft coral Dendronephthya sp. Tetrahedron 2014, 70, 3822-3825. [CrossRef]

120. Chang, F.Y.; Hsu, F.J.; Tai, C.J.; Wei, W.C.; Yang, N.S.; Sheu, J.H. Klymollins T-X, bioactive eunicellin-based diterpenoids from the soft coral Klyxum molle. Mar. Drugs 2014, 12, 3060-3071. [CrossRef]

121. Al-Footy, K.O.; Alarif, W.M.; Asiri, F.; Aly, M.M.; Ayyad, S.-E.N. Rare pyrane-based cembranoids from the Red Sea soft coral Sarcophyton trocheliophorum as potential antimicrobial-antitumor agents. Med. Chem. Res. 2014, 24, 505-512. [CrossRef]

122. Lei, L.-F.; Chen, M.-F.; Wang, T.; He, X.-X.; Liu, B.-X.; Deng, Y.; Chen, X.-J.; Li, Y.-T.; Guan, S.-Y.; Yao, J.-H.; et al. Novel cytotoxic nine-membered macrocyclic polysulfur cembranoid lactones from the soft coral Sinularia sp. Tetrahedron 2014, 70, 6851-6858. [CrossRef]

123. Roy, P.K.; Roy, M.C.; Taira, J.; Ueda, K. Structure and bioactivity of a trisnorditerpenoid and a diterpenoid from an Okinawan soft coral, Cespitularia sp. Tetrahedron Lett. 2014, 55, 1421-1423. [CrossRef] 
124. Cheng, S.Y.; Shih, N.L.; Hou, K.Y.; Ger, M.J.; Yang, C.N.; Wang, S.K.; Duh, C.Y. Kelsoenethiol and dikelsoenyl ether, two unique kelsoane-type sesquiterpenes, from the Formosan soft coral Nephthea erecta. Bioorg. Med. Chem. Lett. 2014, 24, 473-475. [CrossRef]

125. Al-Lihaibi, S.S.; Alarif, W.M.; Abdel-Lateff, A.; Ayyad, S.E.; Abdel-Naim, A.B.; El-Senduny, F.F.; Badria, F.A. Three new cembranoid-type diterpenes from Red Sea soft coral Sarcophyton glaucum: Isolation and antiproliferative activity against HepG2 cells. Eur. J. Med. Chem. 2014, 81, 314-322. [CrossRef]

126. Tseng, Y.J.; Yang, Y.C.; Wang, S.K.; Duh, C.Y. Numerosol A-D, new cembranoid diterpenes from the soft coral Sinularia numerosa. Mar. Drugs 2014, 12, 3371-3380. [CrossRef]

127. Lin, Y.C.; Wang, S.S.; Chen, C.H.; Kuo, Y.H.; Shen, Y.C. Cespitulones A and B, cytotoxic diterpenoids of a new structure class from the soft coral Cespitularia taeniata. Mar. Drugs 2014, 12, 3477-3486. [CrossRef]

128. Zhang, N.X.; Tang, X.L.; van Ofwegen, L.; Xue, L.; Song, W.J.; Li, P.L.; Li, G.Q. Cyclopentenone derivatives and polyhydroxylated steroids from the soft coral Sinularia acuta. Chem. Biodivers. 2015, 12, $273-283$. [CrossRef]

129. Nam, N.H.; Tung, P.T.; Ngoc, N.T.; Hanh, T.T.H.; Thao, N.P.; Thanh, N.V.; Cuong, N.X.; Thao, D.T.; Huong, T.T.; Thung, D.C.; et al. Cytotoxic biscembranoids from the soft coral Sarcophyton pauciplicatum. Chem. Pharm. Bull. 2015, 63, 636-640. [CrossRef]

130. Cheng, S.Y.; Wang, S.K.; Hsieh, M.K.; Duh, C.Y. Polyoxygenated cembrane diterpenoids from the soft coral Sarcophyton Ehrenbergi. Int. J. Mol. Sci. 2015, 16, 6140-6152. [CrossRef]

131. Hsiao, T.H.; Sung, C.S.; Lan, Y.H.; Wang, Y.C.; Lu, M.C.; Wen, Z.H.; Wu, Y.C.; Sung, P.J. New anti-inflammatory cembranes from the cultured soft coral Nephthea Columnaris. Mar. Drugs 2015, 13, 3443-3453. [CrossRef]

132. Koncic, M.Z.; Ioannou, E.; Sawadogo, W.R.; Abdel-Razik, A.F.; Vagias, C.; Diederich, M.; Roussis, V. 4alpha-methylated steroids with cytotoxic activity from the soft coral Litophyton mollis. Steroids 2016, 115, 130-135. [CrossRef]

133. Tsai, T.C.; Huang, Y.T.; Chou, S.K.; Shih, M.C.; Chiang, C.Y.; Su, J.H. Cytotoxic oxygenated steroids from the soft coral Nephthea erecta. Chem. Pharm. Bull. 2016, 64, 1519-1522. [CrossRef]

134. Urda, C.; Fernandez, R.; Perez, M.; Rodriguez, J.; Jimenez, C.; Cuevas, C. Protoxenicins A and B, cytotoxic long-chain acylated Xenicanes from the soft coral Protodendron repens. J. Nat. Prod. 2017, 80, 713-719. [CrossRef]

135. Chao, C.H.; Li, W.L.; Huang, C.Y.; Ahmed, A.F.; Dai, C.F.; Wu, Y.C.; Lu, M.C.; Liaw, C.C.; Sheu, J.H. Isoprenoids from the soft coral Sarcophyton glaucum. Mar. Drugs 2017, 15, 202. [CrossRef]

136. Mohammed, R.; Radwan, M.M.; Ma, G.; Mohamed, T.A.; Seliem, M.A.; Thabet, M.; ElSohly, M.A. Bioactive sterols and sesquiterpenes from the Red Sea soft coral Sinularia terspilli. Med. Chem. Res. 2017, 26, 1647-1652. [CrossRef]

137. Wu, C.H.; Chao, C.H.; Huang, T.Z.; Huang, C.Y.; Hwang, T.L.; Dai, C.F.; Sheu, J.H. Cembranoid-related metabolites and biological activities from the soft coral Sinularia flexibilis. Mar. Drugs 2018, 16, 278. [CrossRef]

138. Livermore, D.M. Has the era of untreatable infections arrived? J. Antimicrob. Chemother. 2009, 64 (Suppl. 1), i29-i36. [CrossRef]

139. Roca, I.; Akova, M.; Baquero, F.; Carlet, J.; Cavaleri, M.; Coenen, S.; Cohen, J.; Findlay, D.; Gyssens, I.; Heuer, O.E.; et al. The global threat of antimicrobial resistance: Science for intervention. New Microbes New Infect. 2015, 6, 22-29. [CrossRef]

140. Hughes, D.; Andersson, D.I. Environmental and genetic modulation of the phenotypic expression of antibiotic resistance. FEMS Microbiol. Rev. 2017, 41, 374-391. [CrossRef]

141. Genilloud, O. The re-emerging role of microbial natural products in antibiotic discovery. Antonie Van Leeuwenhoek 2014, 106, 173-188. [CrossRef]

142. Projan, S.J. Why is big Pharma getting out of antibacterial drug discovery? Curr. Opin. Microbiol. 2003, 6, 427-430. [CrossRef]

143. Bax, R.; Mullan, N.; Verhoef, J. The millennium bugs-The need for and development of new antibacterials. Int. J. Antimicrob. Agents 2000, 16, 51-59. [CrossRef]

144. Zubair, M.; Alarif, W.; Al-Footy, K.; Ph, M.; Ali, M.; Basaif, S.; Al-Lihaibi, S.; Ayyad, S.-E. New antimicrobial biscembrane hydrocarbon and cembranoid diterpenes from the soft coral Sarcophyton trocheliophorum. Turk. J. Chem. 2016, 40, 385-392. [CrossRef]

145. Lou, Z.; Sun, Y.; Rao, Z. Current progress in antiviral strategies. Trends Pharmacol. Sci. 2014, 35, 86-102. [CrossRef] 
146. Lurain, N.S.; Chou, S. Antiviral drug resistance of human cytomegalovirus. Clin. Microbiol. Rev. 2010, 23, 689-712. [CrossRef]

147. Tantillo, C.; Ding, J.; Jacobo-Molina, A.; Nanni, R.G.; Boyer, P.L.; Hughes, S.H.; Pauwels, R.; Andries, K.; Janssen, P.A.J.; Arnold, E. Locations of Anti-AIDS Drug Binding Sites and Resistance Mutations in the Three-dimensional Structure of HIV-1 Reverse Transcriptase: Implications for Mechanisms of Drug Inhibition and Resistance. J. Mol. Biol. 1994, 243, 369-387. [CrossRef]

148. Morfin, F.; Thouvenot, D. Herpes simplex virus resistance to antiviral drugs. J. Clin. Virol. 2003, $26,29-37$. [CrossRef]

149. Wang, S.K.; Hsieh, M.K.; Duh, C.Y. New diterpenoids from soft coral Sarcophyton ehrenbergi. Mar. Drugs 2013, 11, 4318-4327. [CrossRef]

150. Tseng, Y.J.; Wang, S.K.; Duh, C.Y. Secosteroids and norcembranoids from the soft coral Sinularia nanolobata. Mar. Drugs 2013, 11, 3288-3296. [CrossRef]

151. Cheng, S.Y.; Wang, S.K.; Duh, C.Y. Secocrassumol, a seco-cembranoid from the Dongsha Atoll soft coral Lobophytum crassum. Mar. Drugs 2014, 12, 6028-6037. [CrossRef]

152. Yuan, W.; Cheng, S.; Fu, W.; Zhao, M.; Li, X.; Cai, Y.; Dong, J.; Huang, K.; Gustafson, K.R.; Yan, P. Structurally diverse metabolites from the soft coral Sinularia verruca collected in the South China sea. J. Nat. Prod. 2016, 79, 1124-1131. [CrossRef]

153. Yebra, D.M.; Kiil, S.; Dam-Johansen, K. Antifouling technology—past, present and future steps towards efficient and environmentally friendly antifouling coatings. Prog. Org. Coat. 2004, 50, 75-104. [CrossRef]

154. Davidson, I.C.; Brown, C.W.; Sytsma, M.D.; Ruiz, G.M. The role of containerships as transfer mechanisms of marine biofouling species. Biofouling 2009, 25, 645-655. [CrossRef]

155. Schultz, M.P.; Bendick, J.A.; Holm, E.R.; Hertel, W.M. Economic impact of biofouling on a naval surface ship. Biofouling 2011, 27, 87-98. [CrossRef]

156. Omae, I. Organotin antifouling paints and their alternatives. Appl. Organomet. Chem. 2003, 17, 81-105. [CrossRef]

157. Qian, P.-Y.; Xu, Y.; Fusetani, N. Natural products as antifouling compounds: Recent progress and future perspectives. Biofouling 2009, 26, 223-234. [CrossRef]

158. Konstantinou, I.K.; Albanis, T.A. Worldwide occurrence and effects of antifouling paint booster biocides in the aquatic environment: A review. Environ. Int. 2004, 30, 235-248. [CrossRef]

159. Cresswell, T.; Richards, J.P.; Glegg, G.A.; Readman, J.W. The impact of legislation on the usage and environmental concentrations of Irgarol 1051 in UK coastal waters. Mar. Pollut. Bull. 2006, 52, 1169-1175. [CrossRef]

160. Muñoz, I.; Martínez Bueno, M.J.; Agüera, A.; Fernández-Alba, A.R. Environmental and human health risk assessment of organic micro-pollutants occurring in a Spanish marine fish farm. Environ. Pollut. 2010, 158, 1809-1816. [CrossRef]

161. Kwong, T.F.N.; Miao, L.; Li, X.; Qian, P.Y. Novel Antifouling and Antimicrobial Compound from a Marine-Derived Fungus Ampelomyces sp. Mar. Biotechnol. 2006, 8, 634-640. [CrossRef]

162. Shi, H.; Yu, S.; Liu, D.; van Ofwegen, L.; Proksch, P.; Lin, W. Sinularones A-I, new cyclopentenone and butenolide derivatives from a marine soft coral Sinularia sp. and their antifouling activity. Mar. Drugs 2012, 10, 1331-1344. [CrossRef]

163. Chen, D.; Chen, W.; Liu, D.; van Ofwegen, L.; Proksch, P.; Lin, W. Asteriscane-type sesquiterpenoids from the soft coral Sinularia capillosa. J. Nat. Prod. 2013, 76, 1753-1763. [CrossRef]

164. Lai, D.; Geng, Z.; Deng, Z.; van Ofwegen, L.; Proksch, P.; Lin, W. Cembranoids from the soft coral Sinularia rigida with antifouling activities. J. Agric. Food Chem. 2013, 61, 4585-4592. [CrossRef]

165. Zhang, J.; Li, L.-C.; Wang, K.-L.; Liao, X.-J.; Deng, Z.; Xu, S.-H. Pentacyclic hemiacetal sterol with antifouling and cytotoxic activities from the soft coral Nephthea sp. Bioorg. Med. Chem. Lett. 2013, 23, 1079-1082. [CrossRef]

166. Zhang, J.; Liang, Y.; Wang, K.L.; Liao, X.J.; Deng, Z.; Xu, S.H. Antifouling steroids from the South China Sea gorgonian coral Subergorgia suberosa. Steroids 2014, 79, 1-6. [CrossRef]

167. Li, Y.-X.; Wu, H.-X.; Xu, Y.; Shao, C.-L.; Wang, C.-Y.; Qian, P.-Y. Antifouling Activity of Secondary Metabolites Isolated from Chinese Marine Organisms. Mar. Biotechnol. 2013, 15, 552-558. [CrossRef] 
168. Wang, J.; Su, P.; Gu, Q.; Li, W.D.; Guo, J.L.; Qiao, W.; Feng, D.Q.; Tang, S.A. Antifouling activity against bryozoan and barnacle by cembrane diterpenes from the soft coral Sinularia flexibilis. Int. Biodeterior. Biodegrad. 2017, 120, 97-103. [CrossRef]

169. Quang, T.H.; Ha, T.T.; Minh, C.V.; Kiem, P.V.; Huong, H.T.; Ngan, N.T.; Nhiem, N.X.; Tung, N.H.; Thao, N.P.; Thuy, D.T.; et al. Cytotoxic and PPARs transcriptional activities of sterols from the Vietnamese soft coral Lobophytum laevigatum. Bioorg. Med. Chem. Lett. 2011, 21, 2845-2849. [CrossRef]

170. Liang, L.-F.; Kurtán, T.; Mándi, A.; Gao, L.-X.; Li, J.; Zhang, W.; Guo, Y.-W. Sarsolenane and capnosane diterpenes from the Hainan soft coral Sarcophyton trocheliophorum Marenzeller as PTP1B Inhibitors. Eur. J. Org. Chem. 2014, 2014, 1841-1847. [CrossRef]

171. Liu, M.; Zhou, Q.; Wang, J.; Liu, J.; Qi, C.; Lai, Y.; Zhu, H.; Xue, Y.; Hu, Z.; Zhang, Y. Anti-inflammatory butenolide derivatives from the coral-derived fungus Aspergillus terreus and structure revisions of aspernolides $\mathrm{D}$ and $\mathrm{G}$, butyrolactone VI and $4^{\prime}, 8^{\prime \prime}$-diacetoxy butyrolactone VI. RSC Adv. 2018, 8, 13040-13047. [CrossRef]

172. Zheng, C.J.; Shao, C.L.; Guo, Z.Y.; Chen, J.F.; Deng, D.S.; Yang, K.L.; Chen, Y.Y.; Fu, X.M.; She, Z.G.; Lin, Y.C.; et al. Bioactive hydroanthraquinones and anthraquinone dimers from a soft coral-derived Alternaria sp. fungus. J. Nat. Prod. 2012, 75, 189-197. [CrossRef]

173. Li, H.J.; Xie, Y.L.; Xie, Z.L.; Chen, Y.; Lam, C.K.; Lan, W.J. Chondrosterins A-E, triquinane-type sesquiterpenoids from soft coral-associated fungus Chondrostereum sp. Mar. Drugs 2012, 10, 627-638. [CrossRef]

174. Fu, P.; Kong, F.; Wang, Y.; Wang, Y.; Liu, P.; Zuo, G.; Zhu, W. Antibiotic metabolites from the coral-associated Actinomycete Streptomyces sp. OUCMDZ-1703. Chin. J. Chem. 2013, 31, 100-104. [CrossRef]

175. Wang, W.; Liao, Y.; Tang, C.; Huang, X.; Luo, Z.; Chen, J.; Cai, P. Cytotoxic and antibacterial compounds from the coral-derived fungus Aspergillus tritici SP2-8-1. Mar. Drugs 2017, 15, 348. [CrossRef]

176. Wei, M.Y.; Li, D.; Shao, C.L.; Deng, D.S.; Wang, C.Y. ( \pm )-Pestalachloride D, an antibacterial racemate of chlorinated benzophenone derivative from a soft coral-derived fungus Pestalotiopsis sp. Mar. Drugs 2013, 11, 1050-1060. [CrossRef]

177. Zheng, C.J.; Shao, C.L.; Wu, L.Y.; Chen, M.; Wang, K.L.; Zhao, D.L.; Sun, X.P.; Chen, G.Y.; Wang, C.Y. Bioactive phenylalanine derivatives and cytochalasins from the soft coral-derived fungus, Aspergillus elegans. Mar. Drugs 2013, 11, 2054-2068. [CrossRef]

178. Shao, C.L.; Xu, R.F.; Wang, C.Y.; Qian, P.Y.; Wang, K.L.; Wei, M.Y. Potent antifouling marine dihydroquinolin-2(1H)-one-containing alkaloids from the Gorgonian coral-derived fungus Scopulariopsis sp. Mar. Biotechnol. 2015, 17, 408-415. [CrossRef]

179. Jia, Y.-L.; Guan, F.-F.; Ma, J.; Wang, C.-Y.; Shao, C.-L. Pestalotiolide A, a new antiviral phthalide derivative from a soft coral-derived fungus Pestalotiopsissp. Nat. Prod. Sci. 2015, 21, 227. [CrossRef]

180. Bao, J.; Sun, Y.L.; Zhang, X.Y.; Han, Z.; Gao, H.C.; He, F.; Qian, P.Y.; Qi, S.H. Antifouling and antibacterial polyketides from marine gorgonian coral-associated fungus Penicillium sp. SCSGAF 0023. J. Antibiot. 2013, 66, 219-223. [CrossRef]

181. Zhuang, Y.; Teng, X.; Wang, Y.; Liu, P.; Wang, H.; Li, J.; Li, G.; Zhu, W. Cyclopeptides and polyketides from coral-associated fungus, Aspergillus versicolor LCJ-5-4. Tetrahedron 2011, 67, 7085-7089. [CrossRef]

182. Hawas, U.W.; El-Desouky, S.; Abou El-Kassem, L.; Elkhateeb, W. Alternariol derivatives from Alternaria alternata, an endophytic fungus residing in red sea soft coral, inhibit HCV NS3/4A protease. Appl. Biochem. Microbiol. 2015, 51, 579-584. [CrossRef]

183. Zhu, M.; Gao, H.; Wu, C.; Zhu, T.; Che, Q.; Gu, Q.; Guo, P.; Li, D. Lipid-lowering polyketides from a soft coral-derived fungus Cladosporium sp. TZP29. Bioorg. Med. Chem. Lett. 2015, 25, 3606-3609. [CrossRef]

184. Liu, Z.; Xia, G.; Chen, S.; Liu, Y.; Li, H.; She, Z. Eurothiocin A and B, sulfur-containing benzofurans from a soft coral-derived fungus Eurotium rubrum SH-823. Mar. Drugs 2014, 12, 3669-3680. [CrossRef]

185. Liu, M.; Qi, C.; Sun, W.; Shen, L.; Wang, J.; Liu, J.; Lai, Y.; Xue, Y.; Hu, Z.; Zhang, Y. $\alpha$-Glucosidase inhibitors from the coral-associated fungus Aspergillus terreus. Front. Chem. 2018, 6, 422. [CrossRef]

186. Leal, C.M.; Sheridan, C.; Osinga, R.; Dionísio, G.; Rocha, J.R.; Silva, B.; Rosa, R.; Calado, R. Marine Microorganism-Invertebrate Assemblages: Perspectives to Solve the "Supply Problem" in the Initial Steps of Drug Discovery. Mar. Drugs 2014, 12, 3929-3952. [CrossRef]

187. Martins, A.; Vieira, H.; Gaspar, H.; Santos, S. Marketed marine natural products in the pharmaceutical and cosmeceutical industries: Tips for success. Mar. Drugs 2014, 12, 1066-1101. [CrossRef] 
188. Carson, M.A.; Clarke, S.A. Bioactive Compounds from Marine Organisms: Potential for Bone Growth and Healing. Mar. Drugs 2018, 16, 340. [CrossRef]

189. Xue-Mei, H.; Ru-Fang, X.; Yu-Cheng, G.; Chang-Yun, W.; Chang-Lun, S. Biological and Chemical Diversity of Coral-Derived Microorganisms. Curr. Med. Chem. 2015, 22, 3707-3762.

190. Fehmida, B.; Muhammad, F.; Esam, I.A.; Muhammad, Y.; Sana, A.A.; Mohammad, A.K.; Ikram, U.; Muhammad, I.N. Bacteria from Marine Sponges: A Source of New Drugs. Curr. Drug Metab. 2017, 18, 11-15.

191. Thomas, T.R.A.; Kavlekar, D.P.; LokaBharathi, P.A. Marine drugs from sponge-microbe association-a review. Mar. Drugs 2010, 8, 1417-1468. [CrossRef]

192. Raimundo, I.; Silva, S.G.; Costa, R.; Keller-Costa, T. Bioactive Secondary Metabolites from Octocoral-Associated Microbes-New Chances for Blue Growth. Mar. Drugs 2018, 16, 485. [CrossRef]

193. Keller-Costa, T.; Eriksson, D.; Gonçalves, J.M.S.; Gomes, N.C.M.; Lago-Lestón, A.; Costa, R. The gorgonian coral Eunicella labiata hosts a distinct prokaryotic consortium amenable to cultivation. FEMS Microbiol. Ecol. 2017, 93, fix143. [CrossRef]

194. Koren, O.; Rosenberg, E. Bacteria associated with mucus and tissues of the coral Oculina patagonica in summer and winter. Appl. Environ. Microbiol. 2006, 72, 5254-5259. [CrossRef]

195. Nai, C.; Meyer, V. From Axenic to Mixed Cultures: Technological Advances Accelerating a Paradigm Shift in Microbiology. Trends Microbiol. 2018, 26, 538-554. [CrossRef]

196. Brakhage, A.A. Regulation of fungal secondary metabolism. Nat. Rev. Microbiol. 2012, 11, 21-32. [CrossRef]

197. Seyedsayamdost, M.R. High-throughput platform for the discovery of elicitors of silent bacterial gene clusters. Proc. Natl. Acad. Sci. USA 2014, 111, 7266-7271. [CrossRef]

198. Benkendorff, K. 28-Aquaculture and the production of pharmaceuticals and nutraceuticals. In New Technologies in Aquaculture; Burnell, G., Allan, G., Eds.; Woodhead Publishing: Cambridge, UK, 2009; pp. 866-891.

199. Pomeroy, R.S.; Parks, J.E.; Balboa, C.M. Farming the reef: Is aquaculture a solution for reducing fishing pressure on coral reefs? Mar. Policy 2006, 30, 111-130. [CrossRef]

200. Leal, M.C.; Calado, R.; Sheridan, C.; Alimonti, A.; Osinga, R. Coral aquaculture to support drug discovery. Trends Biotechnol. 2013, 31, 555-561. [CrossRef]

201. Mendola, D. Aquaculture of three phyla of marine invertebrates to yield bioactive metabolites: Process developments and economics. Biomol. Eng. 2003, 20, 441-458. [CrossRef]

202. Loureiro, C.; Medema, M.H.; van der Oost, J.; Sipkema, D. Exploration and exploitation of the environment for novel specialized metabolites. Curr. Opin. Biotechnol. 2018, 50, 206-213. [CrossRef]

203. Faisal, M.; Saeed, A.; Shahzad, D. Chapter 5-Portrait of the synthesis of some potent anti-inflammatory natural products. In Discovery and Development of Anti-Inflammatory Agents from Natural Products; Brahmachari, G., Ed.; Elsevier: Amsterdam, The Netherlands, 2019; pp. 141-183.

204. Barbosa, L.C.A.; Varejão, J.O.S.; Varejão, E.V.V. Chapter 3-Strategies for Total Synthesis of Furanocembranolides and Related Natural Products from Marine Organisms. In Studies in Natural Products Chemistry; Atta-ur, R., Ed.; Elsevier: Amsterdam, The Netherlands, 2017; Volume 52, pp. 115-157.

205. Nicolaou, K.C.; Xu, J.Y.; Kim, S.; Pfefferkorn, J.; Ohshima, T.; Vourloumis, D.; Hosokawa, S. Total Synthesis of Sarcodictyins A and B. J. Am. Chem. Soc. 1998, 120, 8661-8673. [CrossRef]

206. Nicolaou, K.C.; Xu, J.Y.; Kim, S.; Ohshima, T.; Hosokawa, S.; Pfefferkorn, J. Synthesis of the Tricyclic Core of Eleutherobin and Sarcodictyins and Total Synthesis of Sarcodictyin A. J. Am. Chem. Soc. 1997, 119, 11353-11354. [CrossRef]

207. Nicolaou, K.C.; van Delft, F.; Ohshima, T.; Vourloumis, D.; Xu, J.; Hosokawa, S.; Pfefferkorn, J.; Kim, S.; Li, T. Total Synthesis of Eleutherobin. Angew. Chem. Int. Ed. Engl. 1997, 36, 2520-2524. [CrossRef]

208. Nicolaou, K.C.; Ohshima, T.; Hosokawa, S.; van Delft, F.L.; Vourloumis, D.; Xu, J.Y.; Pfefferkorn, J.; Kim, S. Total Synthesis of Eleutherobin and Eleuthosides A and B. J. Am. Chem. Soc. 1998, 120, 8674-8680. [CrossRef]

209. Nicolaou, K.C.; Kim, S.; Pfefferkorn, J.; Xu, J.; Ohshima, T.; Hosokawa, S.; Vourloumis, D.; Li, T. Synthesis and Biological Activity of Sarcodictyins. Angew. Chem. Int. Ed. 1998, 37, 1418-1421. [CrossRef]

(C) 2019 by the authors. Licensee MDPI, Basel, Switzerland. This article is an open access article distributed under the terms and conditions of the Creative Commons Attribution (CC BY) license (http://creativecommons.org/licenses/by/4.0/). 